\title{
A pharmacophore-based approach to demonstrating the scope of alcohol dehydrogenases
}

\author{
Katrina S. Madden, ${ }^{* a, b, c}$ Peter M.T. Todd, ${ }^{a}$ Kouji Urata, ${ }^{a}$ Angela J. Russell, ${ }^{\text {d,e }}$ Kylie A. \\ Vincent $^{\mathrm{a}}$ and Holly A. Reeve*a
${ }^{a}$ Department of Chemistry, University of Oxford, Inorganic Chemistry Laboratory, South Parks Road, Oxford, OX1 3QR UK
${ }^{b}$ School of Natural and Environmental Sciences, Bedson Building, Newcastle University, Newcastle Upon Tyne, NE1 7RU UK
cMedicinal Chemistry, Monash Institute of Pharmaceutical Sciences, Monash University, Parkville 3052, Victoria, Australia
${ }^{d}$ Department of Chemistry, University of Oxford, Chemistry Research Laboratory, 12 Mansfield Road, Oxford, OX1 3TA
eDepartment of Pharmacology, University of Oxford, Mansfield Road, Oxford OX1 3QT UK \\ $\underline{\text { holly.reeve@chem.ox.ac.uk, kate.madden@newcastle.ac.uk }}$
}

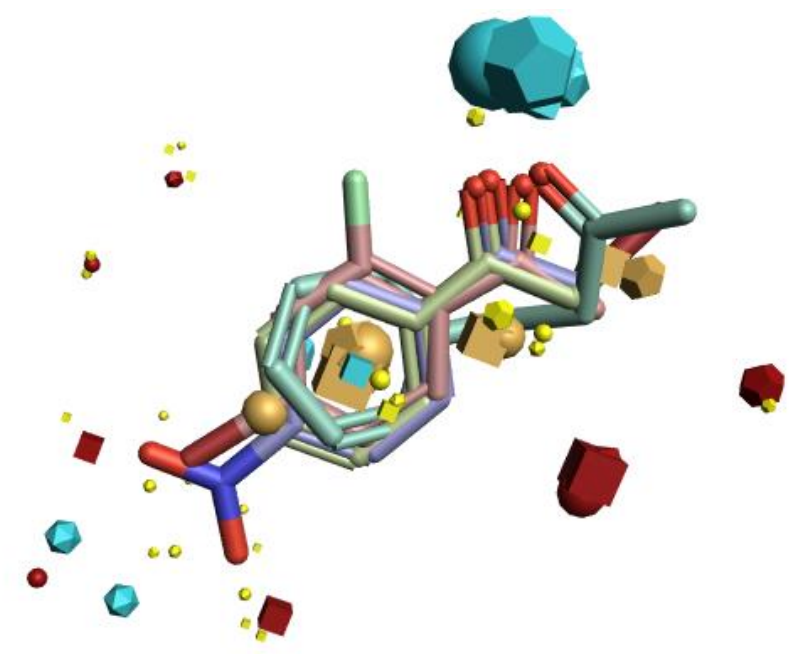

\begin{abstract}
Barriers to the ready adoption of biocatalysis into asymmetric synthesis for early stage medicinal chemistry are addressed, using ketone reduction by alcohol dehydrogenase as a model reaction. An efficient substrate screening approach is used to show the wide substrate scope of commercial alcohol dehydrogenase enzymes, with a high tolerance to chemical groups employed in drug discovery (heterocycle, trifluoromethyl and nitrile/nitro groups) observed. We use our screening data to build a preliminary predictive pharmacophore-based screening tool using Forge software, with a precision of $0.67 / 1$, demonstrating the potential for developing substrate screening tools for commercially available enzymes without publically available structures. We hope that this work, combined with our simple protocols for scaleable $\mathrm{H}_{2}$-driven biocatalytic ketone reduction, will facilitate a culture shift towards adopting biocatalysis alongside traditional chemical catalytic methods.
\end{abstract}




\section{Introduction}

Biocatalysis is now well established in late stage medicinal chemistry, providing elegant solutions to asymmetric synthesis of complex molecules, achieving high yields and selectivity under mild reaction conditions. ${ }^{1-5}$ Such biotransformations have been incorporated into numerous large-scale drug syntheses, but typically rely on time- and resource-intensive methods for evolution or design of a highly optimised enzyme. ${ }^{6-}$

${ }^{11}$ Development of greener, more efficient procedures throughout early stage drug discovery is highly desirable, potentially saving time and resources down the line when optimising a synthetic route for large scale production. ${ }^{1-3,7,12-14}$

In early stage drug discovery, the medicinal chemist's focus is on rapidly accessing a large range of chemical space to develop Structure Activity Relationships (SARs). The initial synthetic method of choice will likely be a 'tried-and-tested' route that has high versatility and can be employed to rapidly furnish a large number of structurally diverse analogues. Current preferred methods are rich in organic and metal catalysts supported by a wealth of literature detailing their use across a broad range of functionalities. ${ }^{15}$

Commercial biocatalysts, such as alcohol dehydrogenases, are readily available and have often been engineered to achieve broad substrate scope for ketone reduction, with high activity, stability and industrial suitability with respect to solvent tolerance and simple production at large scale. However, the sequences of commercial enzymes are typically not made available. This, combined with limited information published in the literature on the breadth of substrate scope tolerated by a given commercial enzyme represents a barrier to straightforward incorporation of commercial enzymes into a medicinal chemist's synthetic repertoire. ${ }^{16}$ Additionally, enzymes for ketone reduction rely on biological reducing agents, such as NADH, for their catalytic activity. Due to the high expense of $\mathrm{NADH}$, a cofactor recycling system must be included, adding complexity to the overall process. Consequently, biocatalysis can be viewed as a 'black box', perceived to require a good deal of expertise to both identify a suitable enzyme then to optimise and implement a biocatalytic process.

However, expanding the application of biocatalysis throughout drug discovery is timely, ${ }^{17-19}$ as there is an increasing appreciation of the importance of 3D character and chirality in medicinal chemistry design, ${ }^{20,21}$ with biocatalytic technologies becoming increasingly sophisticated. ${ }^{2,13,22-26}$ Such methods could provide ready access to enantioenriched building blocks. Recent work by Turner and co-workers demonstrated the potential for transaminases to catalyse the synthesis of chiral amines from ketones, showing a promising substrate scope for a pharmaceutically-relevant transformation. ${ }^{27}$

Our approach is to use standard activity screening techniques, applying medicinal chemistry considerations towards substrate selection and prediction modelling to interrogate the potential of the enzyme to catalyst chemical reactions relevant to medicinal chemistry. Here, we focus on ketone reductions by alcohol dehydrogenase enzymes. We probe the substrate scope of commercial ( $R$ )-alcohol dehydrogenase (ADH) and (S)-ADH, selecting test substrates to cover a wide range of chemical space and incorporate medicinal chemistryrelevant functional groups e.g. heterocycles, $\mathrm{F}$ atoms or other halogens for further derivatisation. ${ }^{28} \mathrm{The}$ ADH enzymes used within this study are commercial and have been engineered for a broad substrate scope. Whereas substrate scope for a native enzyme or its genetic variant can be assessed by in silico docking of substrates into the crystallographically-determined 3D protein structure or a homology model of the structure, this is not possible for commercial enzymes where sequences and structures are generally not made publically available. Predicting substrate scope under these conditions is therefore reminiscent of phenotypic drug discovery, where molecule design proceeds in the absence of a protein structure. Here, compound design follows a pharmacophore-based approach, with design rationale based on interpreting trends between active compounds rather than how individual compounds interact directly with the protein of interest. Modelling approaches in this field focus on predicting the relationship between compound properties e.g. electrostatic field and activity, rather than target-based docking methods. This provides us with an opportunity to employ the tools available for medicinal chemistry, in this case the pharmacophore-based modelling software Forge, to develop a screening tool which predicts the likely reactivity of a substrate based on its chemical features, without requiring any structural knowledge of the enzyme. ${ }^{29}$ This strategy represents an accessible approach to evaluating substrate scope, that we hope will encourage the uptake of biocatalysis in early-stage medicinal 
chemistry, offering a degree of reassurance that an enzyme will display desirable activity for a given set of reactions.

\section{Results and Discussion}

Our focus was to address three key areas of biocatalysis with relevance to medicinal chemistry:

- Suitability for use in diverse synthesis

- Ease of use without specialist equipment

- Confidence in biocatalysis as a go-to method

We sought to assess the substrate scope of two commercially available ADH enzymes with opposite enantioselectivities, (R)-ADH (Johnson Matthey, ADH101) and (S)-ADH (Johnson Matthey, ADH105), as defined with respect to their reduction of acetophenone $\mathbf{1}$, in order to evaluate their potential tolerance for drug-like motifs. The descriptors $(R)$ and $(S)$ used throughout this manuscript refer to the ADH enzyme used and not to the absolute configuration of products formed. These enzymes are known to have broad substrate scope and, as is typical for alcohol dehydrogenases (ketone reductases), use NAD(P)H cofactor as a source of hydride for the $\mathrm{C}=\mathrm{O}$ reduction. Standard $\mathrm{NADH}$-consumption screening techniques were used to determine the rate of NADH oxidation, which was taken as a read-out for ketone reduction. Product verification was carried out for a subset of reactions, and should be completed before commencing scale up work. Taking insight from the drug discovery field, here we push the substrate screens further into medicinal chemistry space to access their practicality. Further information on the activity and selectivity of alcohol dehydrogenases is widely reported. ${ }^{30,31}$

\section{Suitability for and ease of use in diverse synthesis}

In order to rapidly build a picture of the substrate scope of these ADHs, we elected to screen substrates in a 96-well plate format and monitor the reactions via consumption of NADH over time, using UV-Vis spectroscopy (see Supplementary Information for full details on assay set up). Our rationale was to use the specific enzyme activity (SEA, nmol min ${ }^{-1} \mathrm{mg}^{-1}$ of enzyme) for NADH consumption as a readout for reactivity with the substrate. As both ADHs are well characterised for reduction of acetophenone 1, it was included in substrate and condition screens to provide a positive control and benchmark for reactivity.

Initially, we screened over 40 substrates with (S)-ADH and (R)-ADH in $50 \mathrm{mM}$ Tris $\mathrm{HCl}$ buffer (Figure 1a, reaction conditions (i)), selecting acetophenone analogues to cover a range of chemical space and beginning to include drug-like motifs. We immediately observed a surprisingly good tolerance for a range of motifs, including fluoropyridine $\mathbf{2 3}$, halobenzenes $\mathbf{2 - 5}$, homologation of the alkyl chain to include longer chain arylated ketones such as 31-33, and non-aromatic ketones 35-36.

The substrate reactivity of the two ADHs differed, exemplified by the unreactivity of nitrobenzene $\mathbf{2 0}$ with (S)$A D H$, but high activity with $(R)-A D H$. Higher specific enzyme activity values were observed in general for $(S)$ $A D H$, along with a higher level of background NADH-oxidising activity (see Supplementary Information for details), which was taken into account when evaluating the reactivity towards the various substrates.

Solubility in water was a challenge, particularly for substrates incorporating increasingly lipophilic groups, where heavy precipitation was often observed. We therefore investigated the tolerance of the $(R) /(S)$-ADH system to varying percentages of a range of organic solvents with the aim of identifying a bilayer or miscible co-solvent system, suitable for both the enzyme and for improving the solubility of organic compounds (Figure 1b). Low concentrations of dimethylsulfoxide, ethyl acetate and dichloromethane were tolerated, as well as hexane in a bilayer comprising up to $80 \%$ of the total solvent volume. Both ethyl acetate and dichloromethane damaged the integrity of the 96-well plates, therefore their use would require an alternative screening method. However, hexane appeared consistently well tolerated and was compatible with the plasticware, therefore $20 \%$ hexane was selected as a balance between minimising the proportion of organic solvent and maximising substrate availability.

We then rescreened the substrates in Figure 1a utilising the $20 \%$ hexane bilayer (conditions (ii)), and extended the substrate scope to include those in Figure 2, incorporating drug-like motifs such as $\mathrm{CF}_{3}$ pyridine $\mathbf{4 9}$, nitrile 58, pyrazine 52, pyrazole 55-56, methanesulfonamide 57, and pyrimidine $\mathbf{5 1}$. We found that solubility 


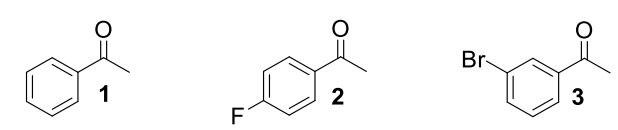

(R) (S)

(i) $43.1 \quad 142$

(ii) $54.1 \quad 99.1$
(R) (S)

$19.9 \quad 1.90$ 12.2142 $38.0 \quad 39.5$<smiles>CC(=O)c1ccccc1Br</smiles><smiles>CC(=O)c1ccc(Br)cc1</smiles>

(R) (S)

\section{(R) (S)}

38.156 .1

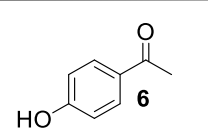

$\underbrace{\mathrm{OH}}_{7}$

$\mathrm{HO}$<smiles>CC(=O)c1ccccc1</smiles>

$\begin{array}{cc}\text { (R) } & (S) \\ - & 39.5 \\ - & 31.5\end{array}$

$\begin{array}{ll}\text { (R) } & (S) \\ 11.3 & 23.1\end{array}$

(R) (S)

$4.76 \quad 82.4$ $14.8 \quad 157$<smiles>COc1ccccc1C(C)=O</smiles><smiles>CCc1ccc(OC)c(C(C)=O)c1</smiles>

(R) (S)

(i) 112 -

(ii) 10.027 .2

\section{(R) (S) \\ $2.46 \quad 13.4$}<smiles>COc1cc(C(C)=O)cc(OC)c1OC</smiles><smiles>CCOc1ccc(C(C)=O)cc1</smiles><smiles>CC(=O)c1ccc2c(c1)OCO2</smiles><smiles></smiles><smiles>CC(=O)c1ccc(Br)c(F)c1</smiles><smiles>CC(=O)c1[14cH][14cH]c(Br)cc1F</smiles><smiles>[13CH3]C(=O)c1cccc(O)c1</smiles><smiles>CC(=O)c1ccc(N)cc1</smiles><smiles>CC(=O)c1ccc([N+](=O)[O-])cc1</smiles>

$19.9 \quad 196$

42.8

$46.3 \quad-$

103242

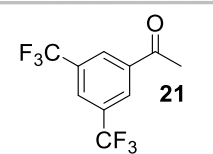<smiles>CC(=O)c1cccnc1</smiles><smiles>CC(=O)c1ccc(F)nc1</smiles><smiles>CC(=O)c1ccc(Cl)nc1</smiles>

(R) (S)

(i) 15.9 -

$$
\begin{array}{ll}
\text { (R) } & (S) \\
-\quad 20.8
\end{array}
$$

(ii) 57.7366

$12.4 \quad 17.4$

\section{(R) (S)}

$130 \quad 593$<smiles>CC(=O)c1ccccn1</smiles>
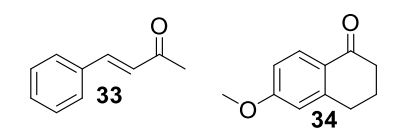<smiles>CC(=O)C1CCCCC1</smiles><smiles>CCCCCCCCC(C)=O</smiles><smiles>O=C1CC2CCN1CC2Cl</smiles>

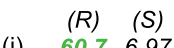

(R) (S)

(ii) $\quad 67.2 \quad 62.1$

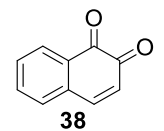

(R) (S)

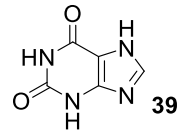

(R) (S)

$\begin{array}{ll}319 & 9.28\end{array}$

15.9<smiles>Cc1cc2c(cc1C)N(C[14CH3])N(C[C@H](O)[C@H](O)[C@H](O)CO)C1=NC(=O)NC(=O)C1=N2</smiles>

(R) (S)

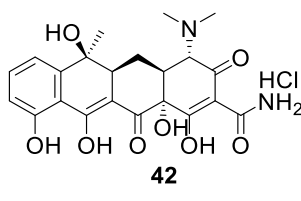

(R) (S)

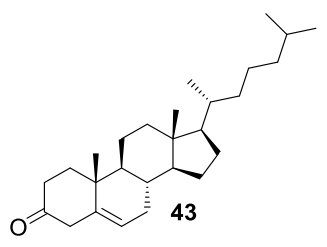

(R) (S)

(ii)
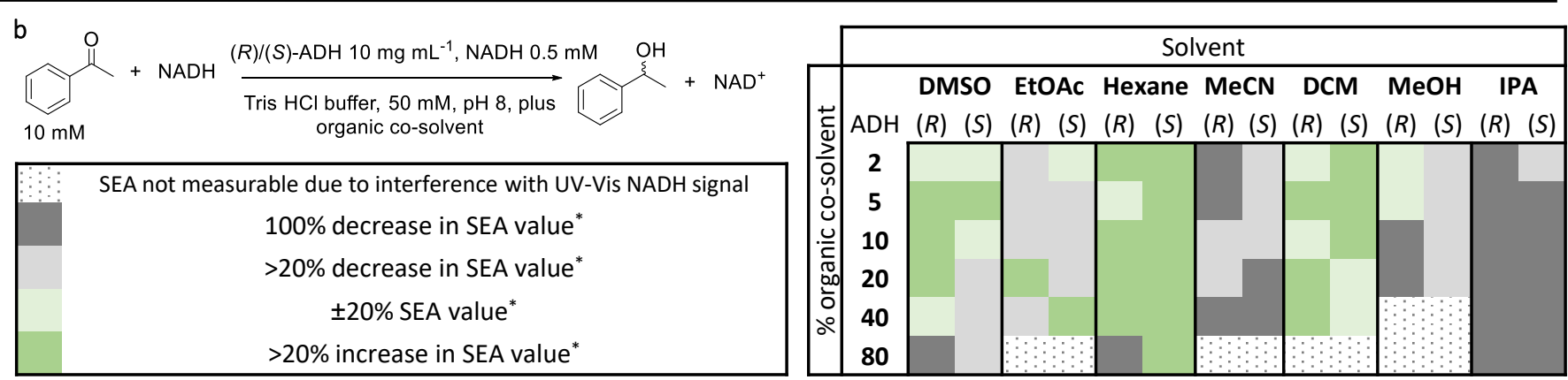

Figure 1 (a) Specific enzyme activity (SEA) values as $\mathrm{nmol} \mathrm{min}^{-1} \mathrm{mg}^{-1}$ for $(R) /(\mathrm{S})-\mathrm{ADH}$, relating to consumption of $\mathrm{NADH}$ cofactor over time The descriptors $(R)$ and $(S)$ within the figure refer to the $A D H$ enzyme used. Values are associated with different conditions: (i) Tris $H C l$ buffer, $\mathrm{pH} 8,50 \mathrm{mM}$ and (ii) 20\% hexane in Tris $\mathrm{HCl}$ buffer, $\mathrm{pH} 8,50 \mathrm{mM}$. UV-vis spectra recorded every 30 seconds for 30 minutes, SEA calculated at $364 \mathrm{~nm}$ with $\varepsilon 3158 \mathrm{M}^{-1} \mathrm{~cm}^{-1}$, with each substrates run at 3 concentrations of $2.5,5$ and $10 \mathrm{mM}$ and the highest SEA value observed of the 3 concentrations reported (concentrations giving the highest SEA value are detailed in the Supplementary Information), results reported to 3 s.f., '-' denotes no consumption of NADH observed, values in green (> $50 \mathrm{nmol} \mathrm{min}^{-1} \mathrm{mg}^{-1}$ ) highlight substrates displaying higher levels of cofactor turnover. (b) Effect of various solvents on the specific enzyme activity (SEA) for (R)/(S)-ADH, relating to consumption of NADH cofactor over time. UV-vis spectra recorded every 30 seconds for 30 minutes, SEA calculated at $364 \mathrm{~nm}$ with $\varepsilon 3158$ $\mathrm{M}^{-1} \mathrm{~cm}^{-1}$, using $10 \mathrm{mM}$ acetophenone as substrate. Abbreviations: dimethylsulfoxide (DMSO), ethyl acetate (EtOAc), acetonitrile (MeCN), dichloromethane (DCM), methanol (MeOH), isopropanol (IPA). * wrt average SEA value obtained for $10 \mathrm{mM}$ acetophenone using $2 \%$ v/v DMSO in $50 \mathrm{mM}$ Tris $\mathrm{HCl}$ buffer. 
presented much less of an issue, with improved specific enzyme activity values observed for a number of substrates previously showing poor solubility in water.

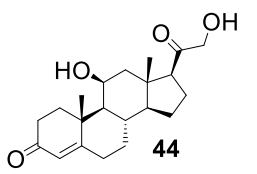

(R) (S)

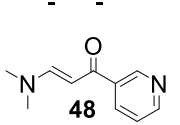

$(R)(S)$

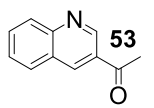

(R) $(S)$

13.7229

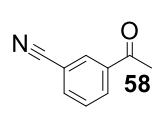

(R) $(S)$

(R3

(R) (S)

59.8220<smiles>CC(C)(C)NC(=O)c1cc(Cl)c(N)c(Cl)c1</smiles>

(R) $(S)$<smiles>O=C1CCC2CC3CCCC3C12</smiles>

(R) (S)<smiles>COc1cc(/C=C/C(=O)C(=O)/C=C/c2ccc(O)c(O)c2)ccc1O</smiles>

(R) (S)

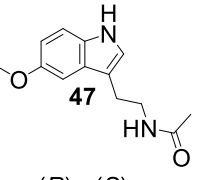

(R) (S)<smiles>CC(=O)c1ccc(C(F)(F)F)[nH]1</smiles><smiles>CC(=O)C1=NC(Br)=CC1</smiles><smiles>CC(=O)c1cnc[n-]1</smiles>

21.7<smiles>[R6]C(=O)c1cnc[nH]1</smiles>

\section{(R) (S)}

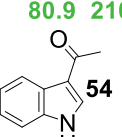

(R) (S)

33.2269

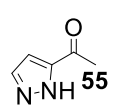

(R) (S)

45.250 .5

(R) (S)

53.2185

$\mathbb{N}_{N} \frac{\mathrm{O}}{56}$

(R) ${ }^{\mathrm{H}}(\mathrm{S})$

$$
\text { (R) (S) }
$$

(R) (S)

14.720 .7

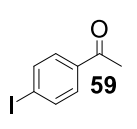

$\underbrace{O_{B}}_{0}$
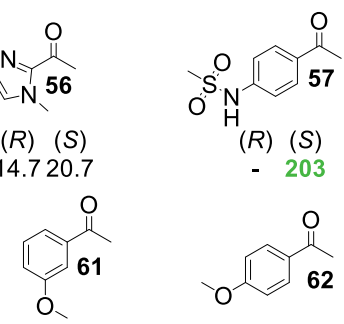

(R) (S)



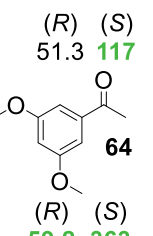

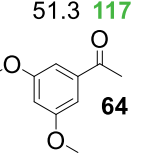

59.2363

(R)

(R) (S)<smiles>CC(=O)c1ccc(CC(C)(N)C(=O)O)cc1</smiles>

$69 \quad 0$

(R) (S)

$10.2 \quad 62.2$

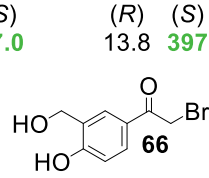

(R) (S)

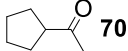

(R) $(S)$

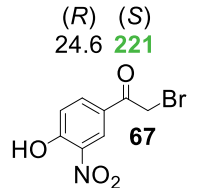

$(R) \quad(S)$

Figure 2 Specific enzyme activity values measured in $\mathrm{nmol} \mathrm{min} \mathrm{m}^{-1} \mathrm{mg}^{-1}$ for $(R) /(\mathrm{S})$-ADH in $20 \%$ hexane bilayer in $50 \mathrm{mM}$ Tris $\mathrm{HCl}$ buffer, relating to consumption of NADH cofactor over time (conditions as detailed in Figure 1 a) (ii)). The descriptors $(R)$ and $(S)$ within the figure refer to the ADH enzyme used. UV-vis spectra recorded every 30 seconds for 30 minutes, SEA calculated at $364 \mathrm{~nm}$ with $\varepsilon 3158 \mathrm{M}^{-1} \mathrm{~cm}^{-}$ 1 , with each substrates run at 3 concentrations of $2.5,5$ and $10 \mathrm{mM}$ and the highest SEA value observed of the 3 concentrations reported (concentrations giving the highest SEA value are detailed in the Supplementary Information), results reported to 3 s.f., '-' denotes no consumption of NADH observed, values in green (>50 nmol min-1 $\mathrm{mg}^{-1}$ ) highlight substrates displaying higher levels of cofactor turnover.

Gratifyingly, both enzymes tolerated a diverse scope of functional groups spanning a range of electronics and sterics. Compatible groups also included those useful for further derivatisation e.g. boronate ester/halogen for further cross-coupling reactions, halogenated heterocycles for subsequent nucleophilic aromatic substitution $\left(S_{N} A r\right)$. We recognised that our substrate scope screens indicate reactivity by measuring consumption of cofactor, rather than tracking product production, which means that structural information about the products is not obtained during screening. In order to shed some light on the integrity of potentially labile groups following $(R) /(S)$-ADH reduction, we tracked the reduction of a series of halogenated acetophenones using $(R) /(S)-A D H$ (for more details, see Supplementary Information), comparing the reactions to samples of both the halogenated products and the de-halogenated alcohol using chiral GC. Here we observed that the halogens were retained in the reduction products, with ees of $98 \%$ or higher measured after 2 hours.

These results, in addition to analogous experiments detailed in our previously published work, give us confidence that sensitive groups such as halogens will be retained in the reduced products. ${ }^{32}$ There were some trends discernible both individually for $(R) /(S)-A D H$, and some general trends in reactivity across both enzymes. For example, 2-OH 7 was not tolerated by either enzyme, and 4-OH 6 was poorly tolerated by (S)-ADH whilst unreactive with $(R)$-ADH. Likewise, pyrazole groups did not appear to be tolerated by either enzyme (55-56). 
In general (S)-ADH displayed higher specific enzyme activity values than $(R)-\mathrm{ADH}$, and was more tolerant of a wider range of substrates eg. phenylmethanesulfonamide 57. However, $(R)$-ADH appeared to better tolerate more chemically diverse substrates such as benzophenone 28 and quinuclidone $\mathrm{HCl}$ 37. Neither enzyme tolerated large and complex bioactive molecules such as steroids 43-45 or the antibiotic tetracycline $\mathbf{4 2}$.

With some preliminary structure-reactivity relationships emerging, and a good level of reactivity for both enzymes observed across chemical space, this screening effort showed clear potential for use of ADHs in diverse chemical synthesis as appropriate to early stage medicinal chemistry.

In order to demonstrate the translation of the above cofactor consumption screens to real-world biocatalytic reduction, a cofactor recycling system is required. This ensures a continuous supply of NADH, and allows substoichiometric quantities of the expensive cofactor to be used. Such cofactor recycling strategies are well established, usually relying on glucose dehydrogenase, or a substrate-couple approach with alcohol dehydrogenase..$^{33}$ Here we use $\mathrm{H}_{2}$-driven biocatalytic cofactor recycling which affords $100 \%$ atom efficient reactions, and simplifies product analysis and isolation, and translates easily into standard hydrogenation laboratory equipment, used on the bench. ${ }^{34}$

We paired ADH-catalysed reduction of 1-(6-(trifluoromethyl)pyridin-3-yl)ethanone $\mathbf{4 9}$ and 3-acetylbenzonitrile 58 with $\mathrm{H}_{2}$-driven cofactor recycling (Figure 3). The experimental set up considerations for these biocatalytic reductions were similar to that of $\mathrm{Pd} / \mathrm{C}$ hydrogenations: reactions could be performed in a fume cupboard under a balloon of hydrogen with solvent degassing, without the requirement for specialist, as detailed in the Supplementary Information. We followed the reductions using NMR and chiral GC, observing excellent conversions, particularly for the (S)-ADH catalysed reductions, where alcohols $\mathbf{7 3}$ and $\mathbf{7 5}$ were produced with near perfect yield and enantioselectivity. We have recently demonstrated $\mathrm{H}_{2}$-driven biocatalytic hydrogenations in the $\mathrm{H}$-cube, utilising enzymes in CatCarts ${ }^{\mathrm{TM}}$, highlighting this approach as a convenient method for scale up. ${ }^{35}$ These results, combined with our previous batch studies of halogenated acetophenones suggest a great deal of promise for the ability to perform biocatalytic reductions on a range of medicinally relevant substrates, whilst retaining high levels of enantioselectivity. This lends strength to the substrate screens previously performed for their translatability to the lab.
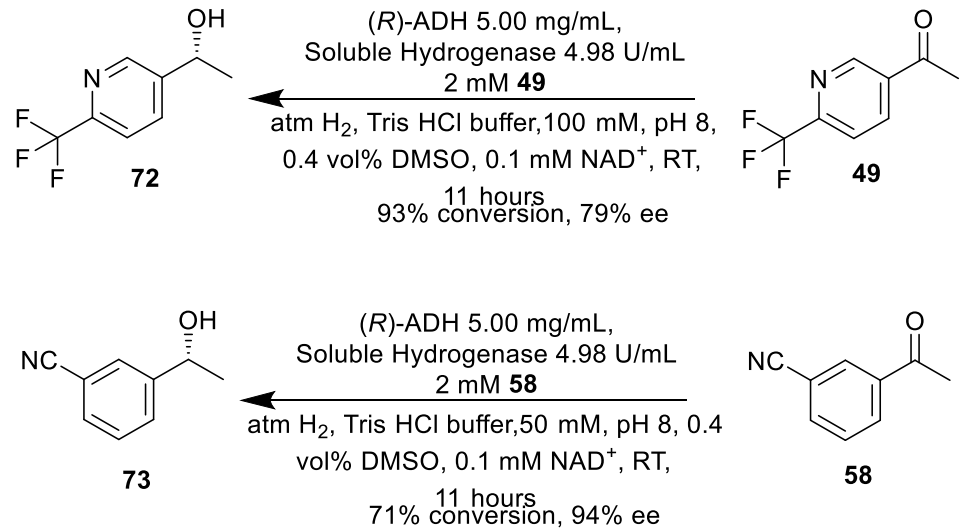

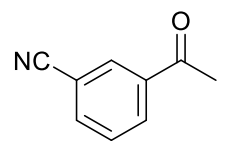

58
(S)-ADH $0.33 \mathrm{mg} / \mathrm{mL}$ Soluble Hydrogenase $0.92 \mathrm{U} / \mathrm{mL}$ atm $\mathrm{H}_{2}$, Tris $\mathrm{HCl}$ buffer, $100 \mathrm{mM}, \mathrm{pH}$, 1.0 vol\% DMSO, $0.1 \mathrm{mM} \mathrm{NAD}^{+}, \mathrm{RT}$, $99 \%$ conversion, $99 \%$ ee

(S)-ADH $0.50 \mathrm{mg} / \mathrm{mL}$ Soluble Hydrogenase $1.38 \mathrm{U} / \mathrm{mL}$ $\frac{2 \mathrm{mM} 58}{\operatorname{atm} \mathrm{H}_{2} \text {, Tris } \mathrm{HCl} \text { buffer,50 mM, pH 8, }}$ 0.4 vol\% DMSO, $0.1 \mathrm{mM} \mathrm{NAD}^{+}$, RT, $99 \%$ conversion, $>99 \%$ ee<smiles>CC(O)c1ccc(C(F)(F)F)nc1</smiles><smiles>C[C@@H](O)c1cccc(C#N)c1</smiles>

74

Figure 3 Reduction of $\mathbf{4 9}$ and $\mathbf{5 8}$ using $\mathrm{H}_{2}$-driven cofactor recycling.

With these results in hand we sought to investigate whether we could identify an alternative ADH enzyme for the reduction of select substrates which displayed poor reactivity with $(R) /(S)-A D H$. These included adrenergic receptor drug precursors 18 and 68 (Table 1 ), the reduced versions of which are $(R)$-phenylephrine and clenbuterol. Whilst pyrazole 55 and 4-hydroxybenzene derivative 6 did not seem to cause cofactor (in this case NADPH) turnover in any of our alternative ADHs, we were pleased to observe that $A D H 20$ appeared to tolerate 18 and 68 , suggesting that it will be possible to develop scaleable biocatalytic reductions of adrenergic receptor drug precursors. A similar approach to substrate screening of these alternative ADHs could open up even more chemical space, in particular allowing for late-stage reductions to furnish drugs such as $(R)$-phenylephrine and clenbuterol, along with a range of other structurally related drugs within this class e.g. levalbuterol $((R)$ salbutamol). 
Table 1 Exploring reactivity of problematic substrates with alternative ADHs (from Johnson Matthey library).

\begin{tabular}{|c|c|c|c|c|}
\hline \multicolumn{5}{|c|}{ ADH $10 \mathrm{mg} \mathrm{mL}^{-1}$, NADPH $0.5 \mathrm{mM}$} \\
\hline \multirow{2}{*}{ Compound } & \multicolumn{4}{|c|}{ Specific Enzyme Activity/ $\mathrm{nmol}^{\mathrm{min}^{-1} \mathrm{mg}^{-1}}$} \\
\hline & ADH19 & ADH2O & ADH61 & ADH150 \\
\hline 6 & 12.8 & - & 12.7 & - \\
\hline 18 & 6.78 & 67.2 & - & 38.6 \\
\hline 28 & - & 41.1 & - & 69.9 \\
\hline 34 & 14.3 & 31.3 & 56.4 & 7.83 \\
\hline 55 & 10.3 & 24.1 & 10.7 & 11.8 \\
\hline 68 & 7.76 & 55.7 & 123 & 33.7 \\
\hline 69 & 10.4 & 18.8 & 29.0 & 6.55 \\
\hline
\end{tabular}

Specific enzyme activity values measured in $50 \mathrm{mM}$ Tris $\mathrm{HCl}$ buffer, relating to consumption of NADPH cofactor over time. UV-vis spectra recorded every 30 seconds for 30 minutes, SEA as nmol min $\mathrm{m} \mathrm{mg}^{-1}$ calculated at $364 \mathrm{~nm}$ with $\varepsilon 3158 \mathrm{M}^{-1} \mathrm{~cm}^{-1}$, with each substrates run at 2 concentrations of 2.5 and 10 $\mathrm{mM}$ and the highest SEA value observed of the 2 concentrations reported (concentrations giving the highest SEA value are detailed in the Supplementary Information)results reported to 3 s.f., '-' denotes no consumption of NADPH observed, values in green (> $50 \mathrm{nmol} \mathrm{min} \mathrm{m} \mathrm{mg}^{-1}$ ) highlight substrates displaying higher levels of cofactor turnover.

\section{Confidence in biocatalysis as a go-to method}

With the sequence of $(R) /(S)$-ADH not publically disclosed, structure-based docking studies into the enzyme active sites were not available to us, and indeed we sought to identify a solution which was more accessible to synthetic chemists, that did not rely on advanced computational skills to assess the potential reactivity of a given substrate. To this end, we instead applied a pharmacophore-based approach to modelling the reactivity of (S)-ADH, using Cresset's Forge software. ${ }^{29}$ The intention behind this was to develop an end user-friendly screening tool which could predict the likely reactivity of a given substrate without the need for knowing the enzyme sequence. We ultimately envisioned an easy to use interface where a synthetic chemist could enter their substrate query and receive a reactivity prediction without needing to manipulate the model themselves. Our strategy was analogous to building 3D Quantitative Structure Activity Relationship (QSAR) models in drug discovery. ${ }^{17,36}$ By aligning low energy conformations of the tested substrates, then using their field properties to generate similarity scores and compare those to their reactivity in the NADH consumption assay, we aimed to generate a pharmacophore-based screening tool which could return an assessment of the likely reactivity of a substrate molecule naïve of the active site sequence. We adopted a pragmatic approach to the development of this tool, focussing on the key information needed by a prospecting synthetic chemist asking the question "will this substrate likely be reduced by $(S)-A D H$ ?"

We therefore categorised the experimentally obtained specific enzyme activity data into 3 categories:

1. Poor reactivity with (S)-ADH (SEA $<30 \mathrm{nmol} \mathrm{min}^{-1} \mathrm{mg}^{-1}$ )

2. Moderate reactivity with (S)-ADH $\left(30<S E A<90 \mathrm{nmol} \mathrm{min}^{-1} \mathrm{mg}^{-1}\right)$

3. Good reactivity with (S)-ADH (SEA $>90 \mathrm{nmol} \mathrm{min}^{-1} \mathrm{mg}^{-1}$ )

This would allow synthetic chemists to filter out potential substrates that have not been tolerated in the past by (S)-ADH whilst minimising the likelihood of missing a possible substrate, something we felt to be important in early stage medicinal chemistry where diverse exploration of chemical space was a key goal.

We partitioned the data obtained using 20\% hexane in Figures 1a and $\mathbf{2}$ into a training set comprising $80 \%$ of the input compounds and an activity stratified test set comprising $20 \%$ of the input compounds. In order to develop the most relevant tool we also used the FieldTemplater module in Forge to identify a general reference pharmacophore from a small number of structurally diverse but reactive substrates (Figure 4). ${ }^{29}$ This process provides a basis for more accurate model building, as it builds up a picture of the different structural features within the substrates that allow for high specific enzyme activity values, providing a general structural reference for reactivity from the data set. 


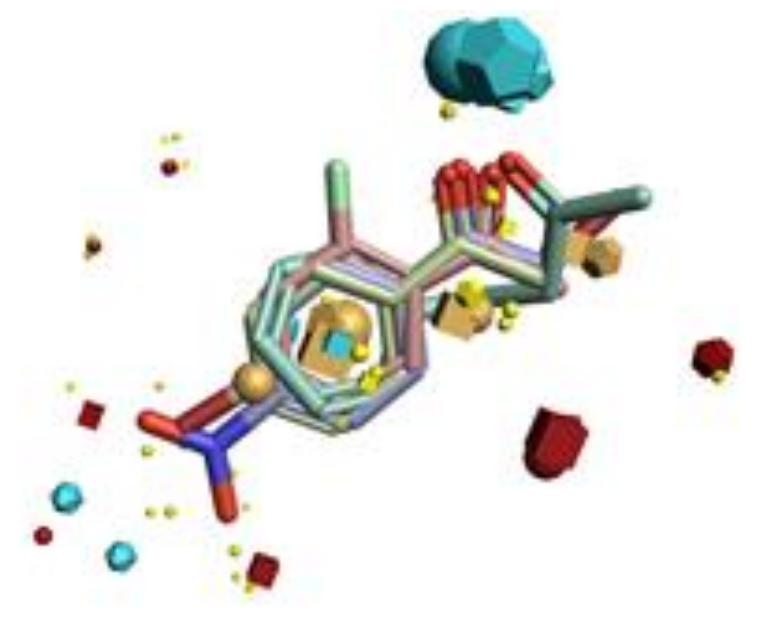

Figure 4 Alignment of substrates used to generate a 'reactive' pharmacophore from a number substrates displaying high SEA values with (S)-ADH with different structural features in FieldTemplater, Forge, Cresset.

Even with our relatively small data set, we were able to generate a screening tool which could correctly assign a reactivity category to the test set compounds with precision and recall values of $0.67 / 1.00$ (for full details see the Supplementary Information). A comparison of predicted and experimentally-determined reactivity categories is shown in Table $\mathbf{2}$. The screening tool correctly predicted the reactivity category for 9 of the 13 test compounds, with the remaining 4 being assigned to a category directly adjacent i.e. predicted category 1 , experimental category 2 . None of the test compounds were predicted to be unlikely to react when the experimental data showed a large specific enzyme activity, or vice versa. Compounds 4 and 10, both orthosubstituted acetophenones, were predicted to be unlikely to react with (S)-ADH- this is perhaps unsurprising when considering the poor reactivity of substrates containing ortho-substituents in the training set (Figure 1a, substrates 7, 9 and 15). Compound 17, however, had a very similar substrate match within the training set in substrate 16, which likely contributed to its correct predicted activity despite the presence of an ortho-F group. In cases where there were more closely matched substrates in the training set, the tool performed well e.g. substrate 5 .

Table 2 Predicted vs experimentally-determined activity category and measured specific enzyme activity (SEA) of test set compounds with (S)-ADH used in the development of a pharmacophore-based screening tool.

\begin{tabular}{|c|c|c|c|}
\hline \multirow[b]{2}{*}{ Compound } & \multicolumn{3}{|c|}{ Reactivity with (S)-ADH } \\
\hline & $\begin{array}{l}\text { Predicted activity } \\
\text { category using Forge } \\
\text { 3D QSAR model }\end{array}$ & $\begin{array}{l}\text { Experimental } \\
\text { activity } \\
\text { category } \\
\end{array}$ & $\begin{array}{l}\text { Measured Specific } \\
\text { Enzyme Activity/ } \\
\text { nmol min-1 } \mathrm{mg}^{-1}\end{array}$ \\
\hline 4 & 1 & 2 & 39.5 \\
\hline 5 & 3 & 3 & 158 \\
\hline 10 & 1 & 2 & 83.0 \\
\hline 17 & 3 & 3 & 366 \\
\hline 21 & 2 & 2 & 57.3 \\
\hline 22 & 3 & 3 & 163 \\
\hline 24 & 3 & 3 & 92.0 \\
\hline 28 & 1 & 1 & 14.3 \\
\hline 37 & 1 & 1 & 23.4 \\
\hline 50 & 3 & 3 & 269 \\
\hline 58 & 2 & 3 & 173 \\
\hline 65 & 2 & 1 & - \\
\hline 68 & 2 & 2 & 34.6 \\
\hline
\end{tabular}

This indicates that a pharmacophore-based model could be developed to act as a highly predictive early stage screening tool, helping the synthetic chemist decide the likelihood of successful reduction of a target ketone by $(S)-A D H$. We anticipate that a more extensive screening campaign to increase the data set will furnish such a screening tool. This premise could be extended beyond our model ADH system, to develop tools for other 
biocatalysts and considerably facilitate the use of enzymes in synthetic chemistry, particularly where the enzyme sequence is not publically known.

\section{Conclusions}

Within this work, we combined multiple approaches (broad and high-throughput substrate screening, targeted enzyme screening and pharmacophore-based model building) to demonstrate the prowess of biocatalysis as a complementary method to traditional organic chemistry. In this case study, we have demonstrated the versatility and tolerance of $(R) /(S)-A D H$ to a wide variety of chemical substrates which could allow for easy access to diverse libraries of compounds with high conversions and enantioselectivity. We then demonstrated facile batch biocatalytic hydrogenation procedures and progress towards a screening tool able to filter out substrates unlikely to be reduced by $(R) /(S)-\mathrm{ADH}$. This shows the clear potential of our approach for predicting the likely reactivity of other enzymes that catalyse an array of highly useful reactions.

We believe this work represents a significant step towards making biocatalysis more accessible, providing the medicinal chemistry community with new ways to incorporate biocatalysts into early stage medicinal chemistry. Our goal is to build on this research, developing robust experimental procedures for the synthesis of milligram quantities of chiral drug-like fragments, focusing on access to diverse chemical space.

\section{Conflicts of interest}

There are no conflicts to declare

\section{Acknowledgements}

K.M., K.U., K.V. and H.R are supported by Engineering and Physical Sciences Research Council (EPSRC) IB Catalyst award EP/N013514/1. We are grateful to Dr Beatriz Dominguez and Johnson Matthey for providing the ADH enzymes used within this study, and Cresset for granting a free evaluation of Forge which was used to perform the modelling aspects of this work. We also thank Dr Sarah Cleary and Dr Jack Rowbotham for their extremely insightful comments and discussions throughout preparation of this manuscript.

\section{References}

A. R. Alcántara, Biocatalysis and pharmaceuticals: A smart tool for sustainable development, MDPI AG, 2019, vol. 9.

N. J. Turner and R. Kumar, Curr. Opin. Chem. Biol., 2018, 43, A1-A3.

B. C. Buckland, D. K. Robinson and M. Chartrain, Metab. Eng., 2000, 2, 42-48.

W. Jiang and B. Fang, Appl. Biochem. Biotechnol., 2020, 1-34.

A. J. Burke, C. S. Marques, N. J. Turner and G. J. Hermann, Active Pharmaceutical Ingredients in Synthesis, Wiley-VCH Verlag GmbH \& Co. KGaA, Weinheim, Germany, 2018.

C. K. Savile, J. M. Janey, E. C. Mundorff, J. C. Moore, S. Tam, W. R. Jarvis, J. C. Colbeck, A. Krebber, F. J. Fleitz, J. Brands, P. N. Devine, G. W. Huisman and G. J. Hughes, Science, 2010, 329, 305-309.

A. A. Desai, Angew. Chemie, Int. Ed. English, 2011, 50, 1974-1976.

F. Parmeggiani, A. Rué Casamajo, D. Colombo, M. C. Ghezzi, J. L. Galman, R. A. Chica, E. Brenna and N. J. Turner, Green Chem. 2019, 21, 4368-4379.

M. A. Huffman, A. Fryszkowska, O. Alvizo, M. Borra-Garske, K. R. Campos, K. A. Canada, P. N. Devine, D. Duan, J. H. Forstater S. T. Grosser, H. M. Halsey, G. J. Hughes, J. Jo, L. A. Joyce, J. N. Kolev, J. Liang, K. M. Maloney, B. F. Mann, N. M. Marshall, M. McLaughlin, J. C. Moore, G. S. Murphy, C. C. Nawrat, J. Nazor, S. Novick, N. R. Patel, A. Rodriguez-Granillo, S. A. Robaire, E. C. Sherer, M. D. Truppo, A. M. Whittaker, D. Verma, L. Xiao, Y. Xu and H. Yang, Science, 2019, 366, 1255-1259.

W. R. Jarvis, J. C. Colbeck, A. Krebber, F. J. Fleitz and J. Brands, Science, 2010, 329, 305-310.

B. A. Anderson, M. M. Hansen, A. R. Harkness, C. L. Henry, J. T. Vicenzi and M. J. Zmijewski, J. Am. Chem. Soc., 1995, 117, 12358-12359.

R. A. Sheldon and J. M. Woodley, Chem. Rev., 2018, 118, 801-838.

P. N. Devine, R. M. Howard, R. Kumar, M. P. Thompson, M. D. Truppo and N. J. Turner, Nat. Rev. Chem., 2018, 2, 409-421.

E. M. M. Abdelraheem, H. Busch, U. Hanefeld and F. Tonin, React. Chem. Eng., 2019, 4, 1878-1894.

C. H. Senanayake, D. R. Fandrick, J. J. Song, C. Busacca, H. C. Shen, J. Yin, W. A. Szabo, V. Yeh, O. R. Thiel, C. K. Chung, L. Terrell and H.-U. Blaser, Applications of Transition Metal Catalysis in Drug Discovery and Development: An Industrial Perspective, John Wiley \& Sons, Inc., New York, 2012.

N. C. Goodwin, J. P. Morrison, D. E. Fuerst and T. Hadi, ACS Med. Chem. Lett., 2019, 10, 1363-1366.

C. Liu, J. Yin, J. Yao, Z. Xu, Y. Tao and H. Zhang, Front. Cell. Infect. Microbiol., 2020, 10, 118.

M. Hönig, P. Sondermann, N. J. Turner and E. M. Carreira, Angew. Chem. Int. Ed., 2017, 56, 8942-8973. 
R. O. M. A. de Souza, L. S. M. Miranda and U. T. Bornscheuer, Chem. - A Eur. J., 2017, 23, 12040-12063.

W. R. J. D. Galloway, A. Isidro-Llobet and D. R. Spring, Nat. Commun., 2010, 1, 1-13.

A. W. Hung, A. Ramek, Y. Wang, T. Kaya, J. A. Wilson, P. A. Clemons and D. W. Young, Proc. Natl. Acad. Sci. U. S. A., 2011, 108, 6799-6804.

K. Faber, W.-D. Fessner and N. J. Turner, Adv. Synth. Catal., 2019, 361, 2373-2376.

K. Chen and F. H. Arnold, Nat. Catal., 2020, 3, 203-213.

C. K. Prier and F. H. Arnold, J. Am. Chem. Soc., 2015, 137, 13992-14006.

M. J. Abrahamson, E. Vazquez-Figueroa, N. B. Woodall, J. C. Moore and A. S. Bommarius, Angew. Chemie-International Ed., 2012, 51, 3969-3972.

G.-D. Roiban, M. Kern, Z. Liu, J. Hyslop, P. L. Tey, M. S. Levine, L. S. Jordan, K. K. Brown, T. Hadi, L. A. F. Ihnken and M. J. B. Brown, ChemCatChem, 2017, 9, 4475-4479.

J. Mangas-Sanchez, M. Sharma, S. C. Cosgrove, J. I. Ramsden, J. R. Marshall, T. W. Thorpe, R. B. Palmer, G. Grogan and N. J. Turner, Chem. Sci., 2020, 11, 5052-5057.

A. A. Koesoema, D. M. Standley, T. Senda and T. Matsuda, Appl. Microbiol. Biotechnol., 2020, 104, 2897-2909.

T. Cheeseright, M. Mackey, S. Rose and A. Vinter, J. Chem. Inf. Model., 2006, 46, 665-676.

H. G. Naik, B. Yeniad, C. E. Koning and A. Heise, Org. Biomol. Chem., 2012, 10, 4961-4967.

Y. G. Zheng, H. H. Yin, D. F. Yu, X. Chen, X. L. Tang, X. J. Zhang, Y. P. Xue, Y. J. Wang and Z. Q. Liu, Appl. Microbiol. Biotechnol., 2017, 101, 987-1001.

J. S. Rowbotham, M. A. Ramirez, O. Lenz, H. A. Reeve and K. A. Vincent, Nat. Commun., 2020, 11, 1454.

A. Weckbecker, H. Groeger and W. Hummel, in Biosystems Engineering I: Creating Superior Biocatalysts, eds. C. Wittmann and W. R. Krull, 2010, vol. 120, pp. 195-242.

L. Lauterbach, O. Lenz and K. A. Vincent, FEBS J., 2013, 280, 3058-3068.

B. Poznansky, L. Thompson, H. Reeve and K. Vincent, ChemRxiv, , DOI:10.26434/CHEMRXIV.12532301.V1.

Q. Gao, L. Yang and Y. Zhu, Curr. Comput. Aided-Drug Des., 2010, 6, 37-49. 


\section{Supplementary information}

\section{Biocatalysis for medicinal chemists; a pharmacophore-based approach to demonstrating the scope of alcohol dehydrogenases}

Katrina S. Madden ${ }^{* a, b}$ Peter M.T. Todd, ${ }^{a}$ Kouji Urata, ${ }^{a}$ Angela J. Russell,,${ }^{c, d}$ Kylie A. Vincent ${ }^{a}$ and Holly A. Reeve*a

\section{Contents}

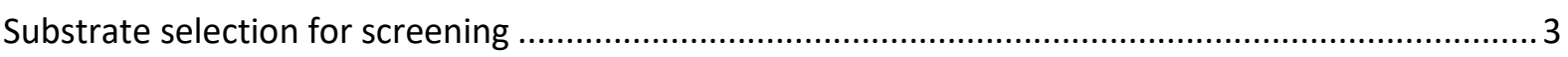

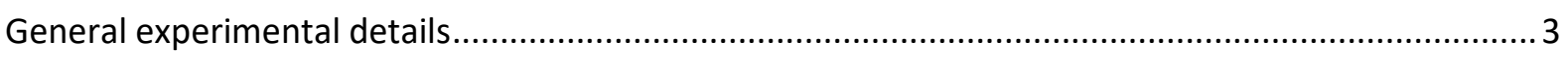

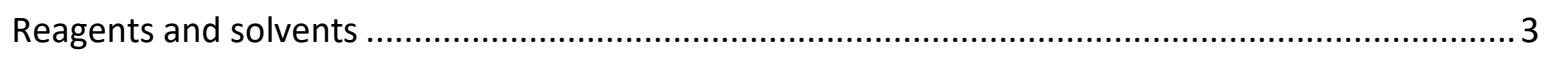

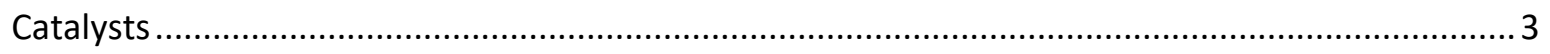

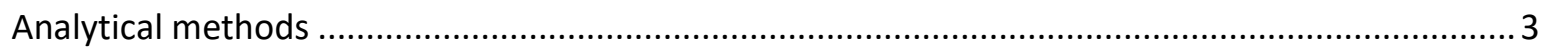

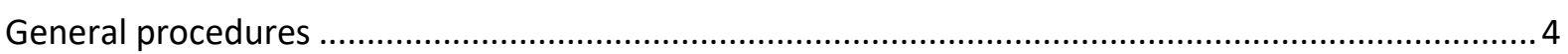

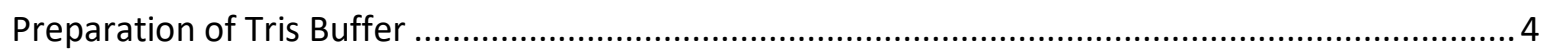

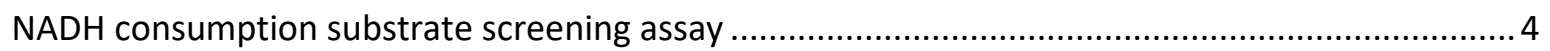

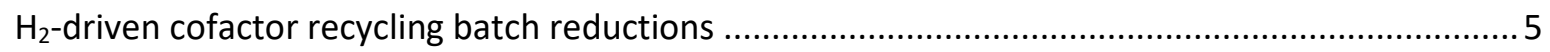

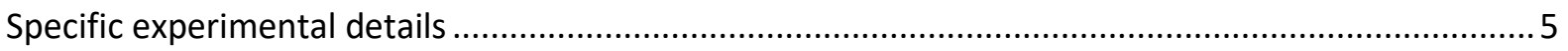

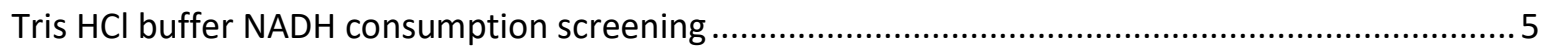

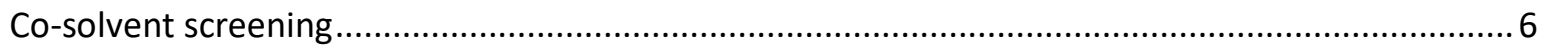

$20 \%$ hexane in Tris $\mathrm{HCl}$ buffer NADH consumption screening ...................................................... 7

Background NADH consumption measurements for ADH ........................................................

GC studies to investigate $e e$ and functional group retention of halogenated acetophenone

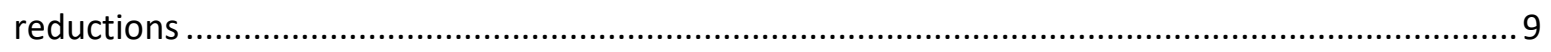

Reduction of $\mathbf{4 9}$ and $\mathbf{5 8}$ using $\mathrm{H}_{2}$-driven cofactor recycling .................................................... 12

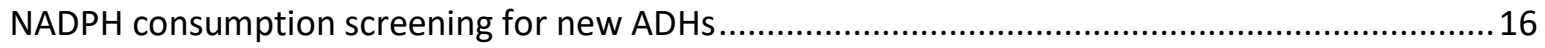

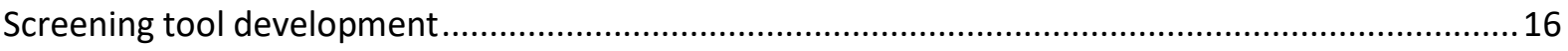

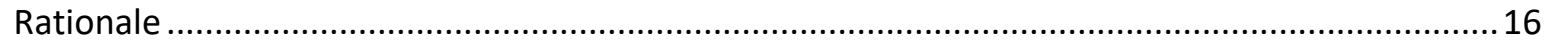

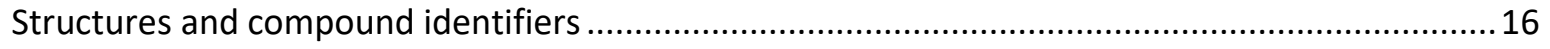

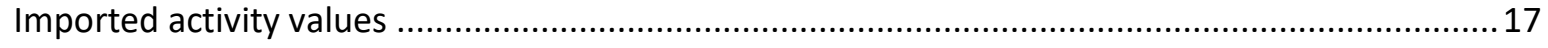

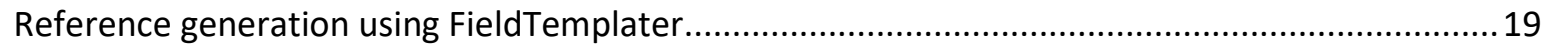

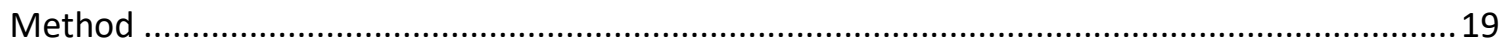

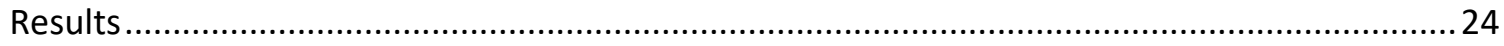

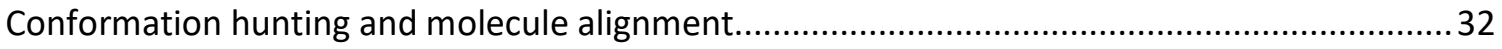

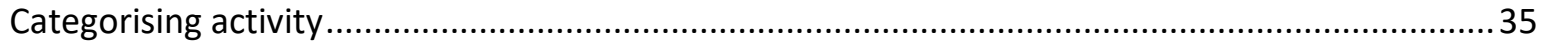

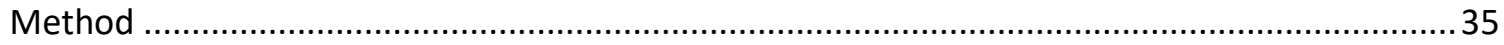




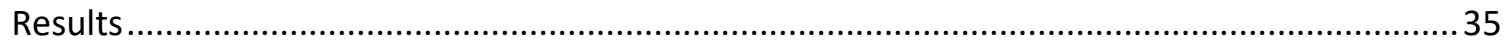

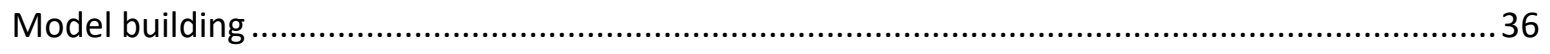

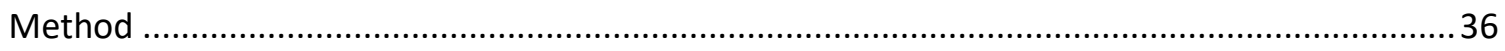

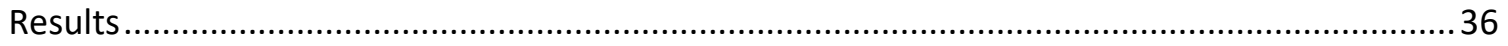

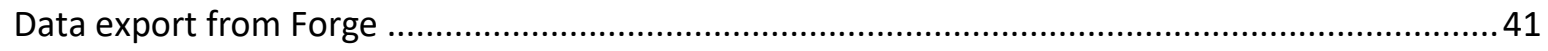

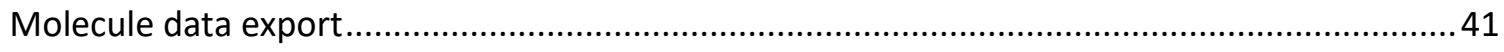

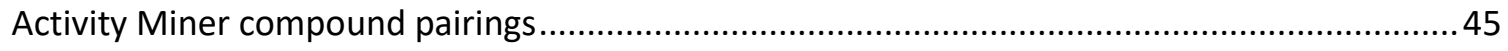

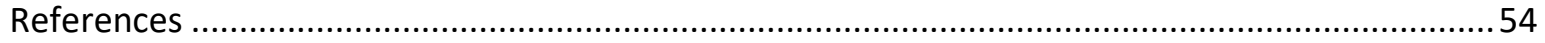




\section{Substrate selection for screening}

Substrate selection for screening against $(R) /(S)$-ADH was heavily influenced by our experience in medicinal chemistry, in addition to commercial availability of precursor ketones. Our experience in phenotypic medicinal chemistry, where compound optimisation is performed without knowledge of the molecular target, was used to select a range of acetophenone-based substrates aiming to cover as wide a range of chemical space as possible. We particularly focussed here on including different types of functional groups in order to see how this might impact reactivity with $(R) /(S)$-ADH. Following initial exploratory substrate selection, we then moved towards assessing substrates with more medicinally relevant functional groups, as governed by our experience in previous drug discovery programmes. Our aim was not to be comprehensive, but more to assess different classes of 'drug-like' motifs to inform pharmacophore-based modelling, and provide a set of substrates familiar to a medicinal chemist as being useful. We also deliberately incorporated a range of substrates with a high degree of complexity and structural disparity to our main substrate set, using bioactive compounds such as steroids. Through these substrate selection processes we aimed to generate a set of data that established a good picture of $(R) /(S)$-ADH substrate tolerance, including examples which would not show any reactivity due to their complexity.

\section{General experimental details}

\section{Reagents and solvents}

Reagents, including substrates for screening and buffer salts, were purchased from a range of commercial suppliers, including Merck, Fluorochem and AlfaAesar. These were used as received without further purification. Substrates were stored as $500 \mathrm{mM}$ stock solutions in DMSO at $4{ }^{\circ} \mathrm{C}$, and were reused for further screening experiments where compound stability allowed. New stock solutions were made up where necessary. NADH and NAD+ cofactors were sourced from Prozomix, stored at $-18^{\circ} \mathrm{C}$, and stock solutions were made up fresh no earlier than 1-2 hours before each experiment. All solutions used in the hydrogenation work were prepared using MilliQ water (Millipore, $18 \mathrm{M} \Omega \mathrm{cm}$ )

\section{Catalysts}

Commercial samples of $(R) /(S)$-ADH (ADH101 and ADH105) were obtained from Johnson Matthey (JM) in lyophilised form, stored at $-18^{\circ} \mathrm{C}$, and used without further purification. Stock solutions were made up fresh immediately before each experiment. Soluble hydrogenase used in this work was from Ralstonia eutropha and prepared in-house.

\section{Analytical methods}

NADH consumption was monitored by UV-Vis spectroscopy, measured at $364 \mathrm{~nm}$. UV-Vis absorbances were either plotted against time $(\mathrm{min})$ as line graphs in Origin, or first converted into $\mathrm{M}$ concentration values using $\varepsilon 3158 \mathrm{M}^{-1} \mathrm{~cm}^{-1}$, as calculated within our laboratory, and then plotted as line graphs of concentration over time $(\mathrm{min})$ in Origin. A linear curve fit was applied to the first 5 minutes of the graph in order to obtain an initial rate (either change in absorbance $\mathrm{min}^{-1}$ or change in NADH concentration $\mathrm{min}^{-1}$ ), and this was then converted into a specific enzyme activity value of $\mathrm{mmol} \mathrm{min} \mathrm{mg}^{-1}$, incorporating $\varepsilon$ for NADH at $364 \mathrm{~nm}$ if this had not already been done.

Chiral phase GC-FID was used to monitor reaction conversion and enantiomeric purity, comparing product and reactant retention times against commercial standards. $300 \mu \mathrm{L}$ of the reaction mixture was extracted with $600 \mu \mathrm{L}$ of EtOAc, before being transferred to the glass vial for chiral phase GC-FID analysis, using the following method: 
Column: CP-Chirasil-Dex CB (Agilent), $25 \mathrm{~m}$ length, $0.25 \mathrm{~mm}$ diameter, $0.25 \mu \mathrm{m}$ (film thickness), fitted with a guard of $10 \mathrm{~m}$ undeactivated fused silica of the same diameter

Carrier: He (CP grade), $170 \mathrm{kPa}$ (constant pressure)

Inlet temperature: $200^{\circ} \mathrm{C}$

Injection conditions: Splitless with split flow $60 \mathrm{~mL} / \mathrm{min}$, splitless time $0.8 \mathrm{mins}$, purge $5 \mathrm{~mL} / \mathrm{min}$. Injection volume $=0.5 \mu \mathrm{L}$.

Detection: FID $\left(\mathrm{H}_{2}=35 \mathrm{~mL} / \mathrm{min}\right.$, air $=350 \mathrm{~mL} / \mathrm{min}$, makeup $\mathrm{N}_{2}=40 \mathrm{~mL} / \mathrm{min}$, temp $\left.=200{ }^{\circ} \mathrm{C}\right)$

Oven heating profile:

$0-5 \mathrm{~min}$, hold at $70^{\circ} \mathrm{C}$

$5-30 \mathrm{~min}$, ramp to $120^{\circ} \mathrm{C}$ at $2{ }^{\circ} \mathrm{C} / \mathrm{min}$

$30-36 \mathrm{~min}$, ramp to $180^{\circ} \mathrm{C}$ at $10^{\circ} \mathrm{C} / \mathrm{min}$

$36-45 \mathrm{~min}$, hold at $180^{\circ} \mathrm{C}$ for 5 minutes

${ }^{1} \mathrm{H}$ NMR analysis was carried out as follows:

$450 \mu \mathrm{L}$ of the reaction mixture was extracted with $800 \mu \mathrm{L}$ of Chloroform $-{ }^{2} \mathrm{H}$, and $600 \mu \mathrm{L}$ was transferred to a Norell ${ }^{\circledR}$ SelectSeries ${ }^{\mathrm{TM}} 5 \mathrm{~mm} 400 \mathrm{MHz}$ NMR sample tube.

${ }^{1} \mathrm{H}$ NMR spectroscopy was carried out on Bruker Avance III (500 MHz) at $298 \mathrm{~K}$, using the following parameters.

\begin{tabular}{|c|c|}
\hline Nucleus & ${ }^{1} \mathrm{H}$ \\
\hline RF pulse energy $(\mathrm{MHz})$ & 499.9 \\
\hline Temperature $(\mathrm{K})$ & $298 \pm 2$ \\
\hline Number of scans & As required \\
\hline Pulse width $(\mu \mathrm{s})$ & 10.3 \\
\hline Spectral width $(\mathrm{Hz})$ & 8000 \\
\hline Acquisition time $(\mathrm{s})$ & 2.04 \\
\hline Relaxation delay $(\mathrm{s})$ & 2.00 \\
\hline
\end{tabular}

\section{General procedures}

\section{Preparation of Tris Buffer}

The required weight of Trizma ${ }^{\circledR}$ base (e.g. $6.06 \mathrm{~g}$ for $500 \mathrm{~mL} 100 \mathrm{mM}$ Tris buffer), was dissolved in the corresponding volume of milliQ water and mixed until complete dissolution. The solution was then corrected to $\mathrm{pH} 8$ with $3 \mathrm{M} \mathrm{HCl}$, using a $\mathrm{pH}$ meter, and sparged overnight with $\mathrm{N}_{2}$ to give the final buffer.

\section{NADH consumption substrate screening assay}

NADH consumption substrate screening assays were performed in ThermoFisher 96 -well clear plastic plates, using single and multi-channel pipettes. The reaction components were added to the wells in the following order: Bulk solvent(s), DMSO where necessary to standardise DMSO concentration across the plate, NADH in Tris buffer, substrate stock solution in DMSO, enzyme. On each addition the component to be added was mixed by pipetting up and down a few times, then the reaction mixture pipetted up and down in the same way after addition. Throughout plate preparation, care was taken to replace pipette tips as necessary to prevent any potential contamination or diluting of 
the components. The plate was swirled in between each addition, ensuring the plate was quickly and carefully swirled on the final addition of enzyme before placing in the reader. For the most consistent results it was important to begin plate reading within 1 minute of adding the enzyme.

NB: For some substrates, particularly within the Tris/water reaction system, a precipitate was formed in the well on addition of substrate stock. For best results it was important to redissolve the substrate as much as possible by more extensive pipetting before addition of the enzyme. Where substrates displayed solubility issues in DMSO, extensive pipetting was performed to homogenise the suspension as much as possible before adding to the well plate. Often in the case of the $20 \%$ hexane:Tris/water bilayer, the substrate would then dissolve in the reaction mixture.

$\mathrm{H}_{2}$-driven cofactor recycling batch reductions

All reactions were set up in a fume hood at room temperature and were conducted on a $1 \mathrm{~mL}$ scale in sealed $2 \mathrm{~mL}$-glass vials under $\mathrm{H}_{2}$ balloon (Supplementary Figure 1). All buffers were pre-saturated by bubbling with $\mathrm{H}_{2}$ gas for at least 30 mins. In order to improve the solubility, dimethylsulfoxide was added, with the final DMSO concentration of 0.1-0.4 vol\%. Tris- $\mathrm{HCl}(100 \mathrm{mM}, \mathrm{pH} 8.0)$ buffer was used for all hydrogenation reactions. Reaction compositions were prepared as specified in the specific experimental procedures, and were stirred at $200 \mathrm{rpm}$. Control experiments were set up in the absence of $\mathrm{SH}$ to ensure there was no background substrate loss. Reaction mixtures were then analysed by Chiral phase GC-FID and ${ }^{1} \mathrm{H}$ NMR to determine conversion and ee.

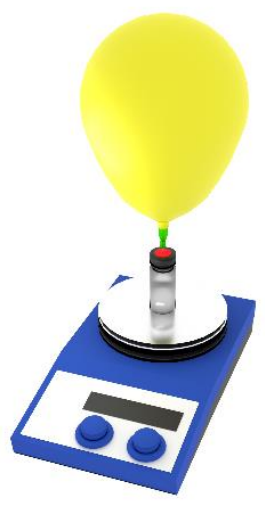

Supplementary Figure 1: The set-up used for batch $\mathrm{H}_{2}$-driven biocatalytic reductions

\section{Specific experimental details}

\section{Tris $\mathrm{HCl}$ buffer $\mathrm{NADH}$ consumption screening}

The general procedure for NADH consumption substrate screening assay was followed, using $50 \mathrm{mM}$ Tris $\mathrm{HCl}$ buffer as the solvent system, prepared by diluting the $100 \mathrm{mM}$ Tris $\mathrm{HCl}$ stock with milliQ water. Each compound was screened at concentrations of 2.5, 5 and $10 \mathrm{mM}$, with the SEA value reported being the highest value obtained out of the 3 concentrations.

Results

\begin{tabular}{|c|c|c|c|c|}
\hline Compound & $\begin{array}{l}\text { Specific Enzyme Activity } \\
(R)-\mathrm{ADH} / \mathrm{nmol} \mathrm{mg}^{-1} \mathrm{~min}^{-1}\end{array}$ & $\begin{array}{c}\text { Concentration/ } \\
\mathrm{mM}\end{array}$ & $\begin{array}{l}\text { Specific Enzyme Activity } \\
\text { (S)-ADH/ } \mathrm{nmol} \mathrm{mg}^{-1} \mathrm{~min}^{-1}\end{array}$ & $\begin{array}{c}\text { Concentration/ } \\
\mathrm{mM} \\
\end{array}$ \\
\hline 1 & 43.1 & 10 & 142 & 2.5 \\
\hline 2 & 26.4 & 10 & 86.4 & 2.5 \\
\hline 3 & 19.9 & 2.5 & 1.90 & 5 \\
\hline
\end{tabular}




\begin{tabular}{|c|c|c|c|c|}
\hline 4 & 75.1 & 5 & 6.37 & 2.5 \\
\hline 5 & 38.1 & 10 & 56.1 & 10 \\
\hline 6 & - & - & 39.5 & 5 \\
\hline 7 & 11.3 & 2.5 & 23.1 & 2.5 \\
\hline 8 & 4.76 & 10 & 82.4 & 10 \\
\hline 9 & 112 & 10 & - & - \\
\hline 10 & 2.46 & 10 & 13.4 & 5 \\
\hline 11 & 49.8 & 5 & 14.1 & 10 \\
\hline 12 & 11.7 & 10 & 154.7 & 10 \\
\hline 13 & 4.37 & 5 & 81.1 & 10 \\
\hline 14 & 17.7 & 10 & 70.1 & 2.5 \\
\hline 15 & - & - & - & - \\
\hline 16 & 46.3 & 10 & - & - \\
\hline 17 & 15.9 & 10 & - & - \\
\hline 18 & - & - & 20.8 & 2.5 \\
\hline 19 & 5.03 & 5 & 21.3 & 10 \\
\hline 20 & 99.9 & 2.5 & - & - \\
\hline 21 & 4.51 & 5 & 29.6 & 5 \\
\hline 22 & 9.45 & 10 & 121 & 10 \\
\hline 23 & 24.7 & 10 & 182 & 10 \\
\hline 24 & 32.2 & 5 & 371 & 2.5 \\
\hline 25 & 22.2 & 10 & 70.4 & 10 \\
\hline 26 & 9.22 & 5 & 19.1 & 10 \\
\hline 27 & 44.6 & 5 & 18.7 & 5 \\
\hline 28 & 35.7 & 5 & 12.8 & 5 \\
\hline 29 & 83.1 & 10 & 131 & 10 \\
\hline 30 & 7.68 & 5 & - & - \\
\hline 31 & 5.98 & 10 & 274 & 10 \\
\hline 32 & 109 & 10 & - & - \\
\hline 33 & 60.7 & 10 & 6.97 & 2.5 \\
\hline 34 & 6.90 & 2.5 & 9.00 & 10 \\
\hline 35 & 167 & 10 & 233 & 10 \\
\hline 36 & 39.5 & 10 & 8.95 & 5 \\
\hline 37 & - & - & 13.0 & 10 \\
\hline 38 & - & - & - & - \\
\hline 39 & 319 & 10 & 9.28 & 2.5 \\
\hline 40 & - & - & - & - \\
\hline 41 & - & - & - & - \\
\hline 42 & - & - & - & - \\
\hline 43 & - & - & - & - \\
\hline
\end{tabular}

Co-solvent screening

The general procedure for NADH consumption substrate screening assay was followed, using varying concentrations of a range of solvents as specified below in $50 \mathrm{mM}$ Tris $\mathrm{HCl}$ buffer as the solvent system, and AcPh 1 throughout the experiment at a concentration of $10 \mathrm{mM}$. 
Results

\begin{tabular}{|c|c|c|c|c|c|c|c|}
\hline & \multicolumn{7}{|c|}{ Specific enzyme activity/ $\mathrm{nmol} \mathrm{min}^{-1} \mathrm{mg}^{-1}$} \\
\hline $\begin{array}{l}\text { Enzyme and } \\
\% \text { solvent } \mathrm{v} / \mathrm{v}\end{array}$ & DMSO & EtOAc & Hexane & $\mathrm{MeCN}$ & DCM & $\mathrm{MeOH}$ & IPA \\
\hline$(R)$-ADH $2 \%$ & 26.0 & 12.6 & 42.5 & - & 19.8 & 22.4 & - \\
\hline (R)-ADH 5\% & 57.7 & 14.7 & 26.5 & - & 43.9 & 22.6 & - \\
\hline$(\boldsymbol{R})$-ADH $10 \%$ & 46.2 & 10.2 & 43.0 & 18.3 & 21.1 & - & - \\
\hline$(R)-A D H ~ 20 \%$ & 75.3 & 42.6 & 29.4 & 4.56 & 35.2 & - & - \\
\hline$(R)-A D H 40 \%$ & 27.6 & 15.1 & 68.4 & - & 31.9 & - & - \\
\hline$(R)-A D H ~ 80 \%$ & - & - & - & - & - & - & - \\
\hline (S)-ADH 2\% & 54.9 & 47.8 & 114 & 15.1 & 90.5 & 40.6 & 12.3 \\
\hline (S)-ADH 5\% & 69.5 & 39.2 & 120 & 21.8 & 84.1 & 27.6 & - \\
\hline (S)-ADH 10\% & 55.3 & 24.0 & 82.9 & 22.1 & 94.3 & 35.1 & - \\
\hline (S)-ADH 20\% & 25.9 & 9.02 & 104 & - & 50.2 & 37.7 & - \\
\hline (S)-ADH 40\% & 4.52 & 73.6 & 169 & - & 59.3 & - & - \\
\hline (S)-ADH 80\% & 3.49 & - & 147 & - & - & - & - \\
\hline
\end{tabular}

Controls

\begin{tabular}{|c|c|c|}
\hline $\begin{array}{c}\text { Specific enzyme activity/ nmol } \\
\text { min }^{-1} \mathbf{~ m g}^{-1}\end{array}$ & Conditions & \multirow{2}{*}{ Enzyme } \\
\hline 24.7 & (R)-ADH \\
\hline 24.6 & AcPh 1, 10 mM, 2\% DMSO & \\
\hline 17.6 & AcPh 1, 10 mM, 2\% DMSO & \multirow{2}{*}{ (S)-ADH } \\
\hline 80.3 & AcPh 1, 10 mM, 2\% DMSO & \\
\hline 39.1 & AcPh 1, 10 mM, 2\% DMSO & \\
\hline 52.1 & AcPh 1, 10 mM, 2\% DMSO & \\
\hline
\end{tabular}

\begin{tabular}{|c|c|}
\hline & $\begin{array}{c}\text { Average AcPh specific enzyme } \\
\text { activity/ } \mathbf{~ m o l ~} \text { min }^{-1} \mathbf{~ m g}^{-1}\end{array}$ \\
\hline$(R)$-ADH & 23.2 \\
\hline stdev & 3.81 \\
\hline (S)-ADH & 56.6 \\
\hline stdev & 17.2 \\
\hline
\end{tabular}

Effect on specific enzyme activity determined by calculating the percentage change with respect to the average AcPh control values.

20\% hexane in Tris $\mathrm{HCl}$ buffer NADH consumption screening The general procedure for NADH consumption substrate screening assay was followed, using $20 \%$ hexane in $50 \mathrm{mM}$ Tris $\mathrm{HCl}$ buffer as the solvent system. Each compound was screened at concentrations of 2.5, 5 and $10 \mathrm{mM}$, with the SEA value reported being the highest value obtained out of the 3 concentrations. 
Results

\begin{tabular}{|c|c|c|c|c|}
\hline Compound & $\begin{array}{c}\text { Specific Enzyme } \\
\text { Activity } \\
\text { (R)-ADH/ nmol mg-1 } \\
\mathrm{min}^{-1}\end{array}$ & Concentration/ mM & $\begin{array}{c}\text { Specific Enzyme } \\
\text { Activity } \\
\text { (S)-ADH/ nmol mg-1 } \\
\text { min }^{-1}\end{array}$ & Concentration/ $\mathrm{mM}$ \\
\hline 1 & 54.1 & 10 & 99.1 & 2.5 \\
\hline 2 & 22.9 & 5 & 122.1 & 10 \\
\hline 3 & 12.2 & 5 & 142 & 10 \\
\hline 4 & 38.0 & 5 & 39.5 & 10 \\
\hline 5 & 73.1 & 10 & 158 & 5 \\
\hline 6 & - & - & 31.5 & 2.5 \\
\hline 7 & - & - & - & - \\
\hline 8 & 14.8 & 5 & 157 & 2.5 \\
\hline 9 & 10.0 & 2.5 & 27.2 & 2.5 \\
\hline 10 & - & - & 83.0 & 2.5 \\
\hline 11 & 52.9 & 10 & 64.0 & 10 \\
\hline 12 & - & - & 89.9 & 2.5 \\
\hline 13 & 19.9 & 5 & 196 & 10 \\
\hline 14 & 34.2 & 5 & 189 & 2.5 \\
\hline 15 & 42.8 & 10 & - & - \\
\hline 16 & 103 & 10 & 242 & 10 \\
\hline 17 & 57.7 & 10 & 366 & 5 \\
\hline 18 & 12.4 & 2.5 & 17.4 & 10 \\
\hline 19 & 43.9 & 2.5 & 80.4 & 5 \\
\hline 20 & 130 & 5 & 593 & 10 \\
\hline 21 & 17.4 & 5 & 57.3 & 10 \\
\hline 22 & 34.0 & 10 & 163 & 10 \\
\hline 23 & 51.0 & 10 & 137 & 10 \\
\hline 24 & 62.5 & 5 & 92.0 & 2.5 \\
\hline 25 & 35.5 & 10 & 60.3 & 10 \\
\hline 26 & 46.2 & 10 & 29.4 & 2.5 \\
\hline 27 & 89.2 & 2.5 & 337 & 10 \\
\hline 28 & 73.9 & 10 & 14.3 & 5 \\
\hline 29 & 87.1 & 2.5 & 112 & 10 \\
\hline 30 & 37.0 & 10 & 54.0 & 2.5 \\
\hline 31 & 22.2 & 5 & 239 & 2.5 \\
\hline 32 & 95.7 & 2.5 & 364 & 10 \\
\hline 33 & 67.2 & 10 & 62.1 & 10 \\
\hline 34 & - & - & 36.0 & 5 \\
\hline 35 & 52.3 & 10 & 112 & 10 \\
\hline 36 & 25.7 & 2.5 & 37.1 & 10 \\
\hline 37 & 85.3 & 2.5 & 23.4 & 2.5 \\
\hline 38 & - & - & - & - \\
\hline 39 & - & - & 15.9 & - \\
\hline 40 & - & - & - & - \\
\hline 41 & - & - & - & - \\
\hline 42 & - & - & - & - \\
\hline
\end{tabular}




\begin{tabular}{|c|c|c|c|c|}
\hline 43 & - & - & - & - \\
\hline 44 & - & - & - & - \\
\hline 45 & - & - & - & - \\
\hline 46 & - & - & - & - \\
\hline 47 & - & - & 21.7 & 2.5 \\
\hline 48 & - & - & - & - \\
\hline 49 & 80.9 & 10 & 210 & 2.5 \\
\hline 50 & 33.2 & 2.5 & 269 & 5 \\
\hline 51 & 45.2 & 10 & 50.5 & 10 \\
\hline 52 & 53.2 & 10 & 185 & 10 \\
\hline 53 & 13.7 & 5 & 229 & 10 \\
\hline 54 & - & - & - & - \\
\hline 55 & 5.62 & 10 & 20.7 & 10 \\
\hline 56 & 14.7 & 2.5 & 20.7 & 2.5 \\
\hline 57 & - & - & 203 & 2.5 \\
\hline 58 & 57.4 & 2.5 & 173 & 2.5 \\
\hline 59 & 51.3 & 10 & 117 & 2.5 \\
\hline 60 & 465 & 5 & 87.0 & 10 \\
\hline 61 & 13.8 & 2.5 & 397 & 10 \\
\hline 62 & 24.6 & 2.5 & 221 & 2.5 \\
\hline 63 & 59.8 & 2.5 & 220 & 10 \\
\hline 64 & 59.2 & 10 & 363 & 10 \\
\hline 65 & - & - & - & - \\
\hline 66 & - & - & - & - \\
\hline 67 & - & - & - & - \\
\hline 68 & - & - & 34.6 & 2.5 \\
\hline 69 & 10.2 & 2.5 & 62.2 & 10 \\
\hline 70 & 123 & 2.5 & 218 & 10 \\
\hline 71 & 82.8 & 10 & 98.2 & 2.5 \\
\hline
\end{tabular}

Background NADH consumption measurements for $\mathrm{ADH}$

Background consumption of NADH was generally consistent for each $A D H$, and was used as a control to provide confidence in the ability to compare results from different screens. Background NADH oxidation was also used as guideline threshold for treating a substrate as having any reactivity with ADH. For (R)-ADH (ADH 101), background SEA was usually below $10 \mathrm{nmol} \mathrm{mg}^{-1} \mathrm{~min}^{-1}$, whereas for (S)ADH (ADH 105), background SEA was generally around $20 \mathrm{nmol} \mathrm{mg}^{-1} \mathrm{~min}^{-1}$.

GC studies to investigate ee and functional group retention of halogenated acetophenone reductions

Reductions were performed using $(R) /(S)$-ADH on acetophenone (AcPh), 4-iodoacetophenone (IAcPh), 4-bromoacetophenone ( $\mathrm{BrAcPh}$ ) and 4-chloroacetophenone ( $\mathrm{ClAcPh}$ ) to assess whether the halogen groups in IAcPh/BrAcPh/ClAcPh were retained.

In a glove box under $\mathrm{N}_{2}$, AcPh/ClAcPh/BrAcPh/IAcPh (20 $\mu \mathrm{L}, 100 \mathrm{mM}$ in DMSO), NADH (40 $\mu \mathrm{L}, 5 \mathrm{mM}$ in Tris $\mathrm{HCl}$ buffer), $(R) /(S)$-ADH $\left(50 \mu \mathrm{L}, 10 \mathrm{mg} \mathrm{mL}^{-1}\right.$ in Tris $\mathrm{HCl}$ buffer) and Tris $\mathrm{HCl}$ Buffer (390 $\mu \mathrm{L}, 100$ $\mathrm{mM}, \mathrm{pH}$ 8.0) were added to $1 \mathrm{~mL}$ Eppendorf tubes and left on a shaker to react. After 2 and 28 
hours, $250 \mu \mathrm{L}$ of each reaction mixture was then extracted with ethyl acetate $(750 \mu \mathrm{L}$, containing 2 $\mathrm{mM}$ undecane). The organic layer was dried with $\mathrm{MgSO}_{4}$, then transferred into a $\mathrm{GC}$ vial for analysis.

Separately, in a glove box under $\mathrm{N}_{2}$, AcPh/ClAcPh/BrAcPh/IAcPh (20 $\mu \mathrm{L}, 100 \mathrm{mM}$ in DMSO), $\mathrm{NaBH}_{4}(5$ $\mathrm{mg}$ ), and Tris $\mathrm{HCl}$ buffer ( $480 \mu \mathrm{L}, 100 \mathrm{mM}, \mathrm{pH} 8.0$ ) were added to $1 \mathrm{~mL}$ Eppendorf tubes and left on a shaker to react for 2 hours. $250 \mu \mathrm{L}$ of each reaction mixture was then extracted with ethyl acetate (750 $\mu \mathrm{L}$, containing $2 \mathrm{mM}$ undecane). The organic layer was dried with $\mathrm{MgSO}_{4}$, then transferred into a GC vial for analysis.

Comparison of reaction mixtures to the racemic product standards produced chemically by $\mathrm{NaBH}_{4}$ reduction, including the standard for 1-phenylethanol (the product of reduction and dehalogenation), showed that the biocatalytic reductions did not cause dehalogenation for the $\mathrm{IAcPh}, \mathrm{BrAcPh}$ and $\mathrm{ClAcPh}$ (Supplementary Figure 2). Dehalogenation was observed for the $\mathrm{NaBH}_{4}$ reductions of $\mathrm{IAcPh}$ and $\mathrm{BrAcPh}$, with considerable deiodination and a modest amount of
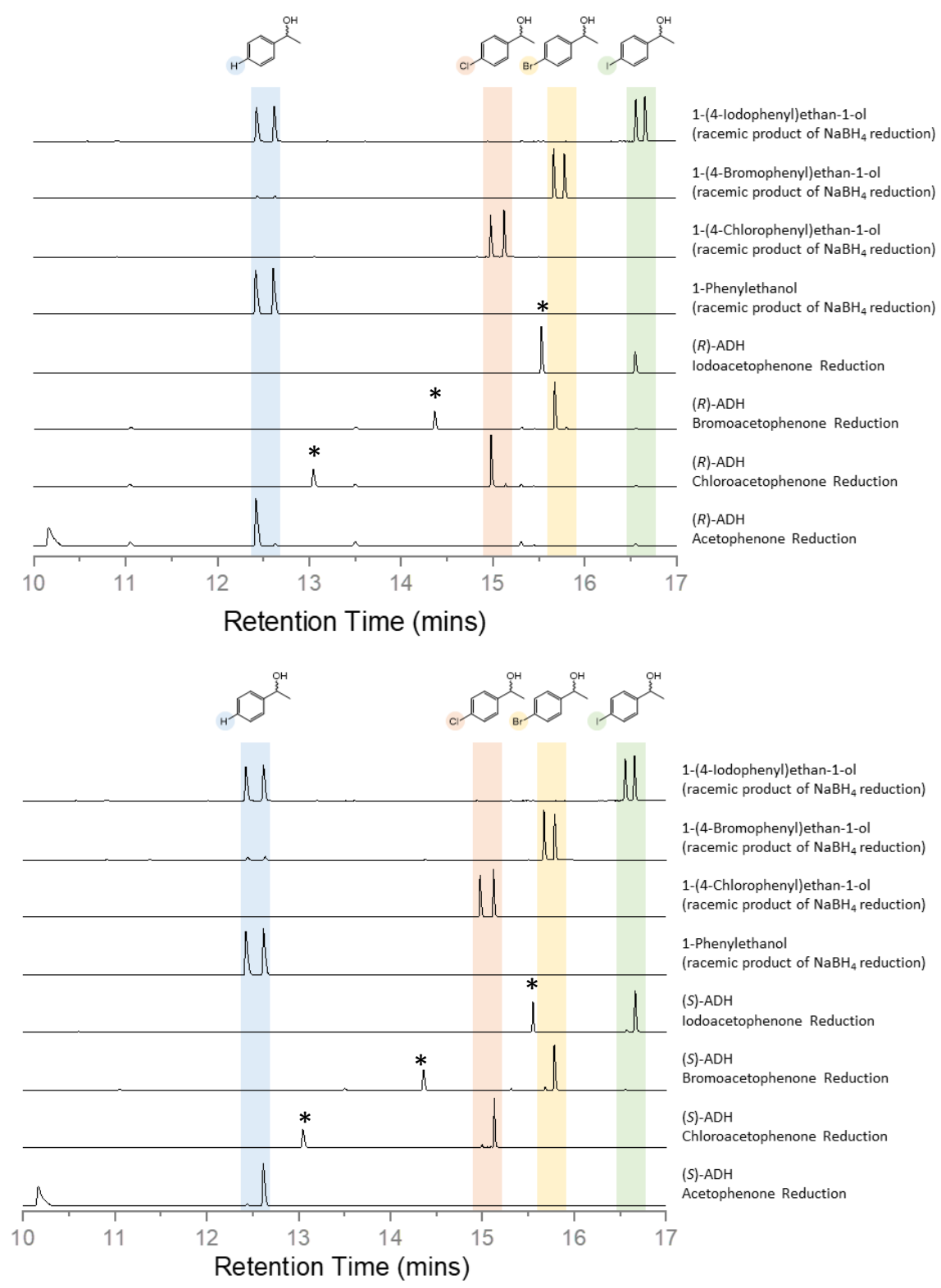

Supplementary Figure 2: Stacked GC chromatograms comparing reductions of $\mathrm{AcPh}, \mathrm{IAcPh}, \mathrm{BrAcPh}$ and $\mathrm{ClAcPh}$ by $(R) /(S)-\mathrm{ADH}$ after 28 hours and $\mathrm{NaBH}_{4}$, ${ }^{*}$ denotes unreacted substrate peak 
debromination observed. The ee values calculated for each reaction at the two time points are shown below. We observed that ee values generally decreased after 28 hours, which we believe to be due to instability of the chiral centres within the products in aqueous solution.

\begin{tabular}{|c|c|c|c|c|c|c|c|c|c|c|}
\hline Reaction & $\begin{array}{c}\text { Undeca } \\
\text { ne Peak } \\
\text { Area }\end{array}$ & $\begin{array}{l}\text { Retention } \\
\text { Time } \\
\text { Substrate } \\
\text { Peak/ min }\end{array}$ & $\begin{array}{c}\text { Area } \\
\text { Substrate } \\
\text { Peak }\end{array}$ & $\begin{array}{l}\text { Retention } \\
\text { Time } \\
R \text {-Product } \\
\text { Peak/ min }\end{array}$ & $\begin{array}{c}\text { Area } R- \\
\text { Product } \\
\text { Peak }\end{array}$ & $\begin{array}{l}\text { Retention } \\
\text { Time } \\
\text { S-Product } \\
\text { Peak/ min }\end{array}$ & $\begin{array}{c}\text { Area } S \text { - } \\
\text { Product } \\
\text { Peak }\end{array}$ & $\begin{array}{l}\text { Dehalog } \\
\text { enation }\end{array}$ & $\begin{array}{c}\text { GC } \\
\text { Conve } \\
\text { rsion }\end{array}$ & $\begin{array}{c}\text { Enantio } \\
\text { meric } \\
\text { Excess }\end{array}$ \\
\hline $\begin{array}{c}\mathrm{AcPh}+(R)- \\
\mathrm{ADH}(2 \mathrm{~h})\end{array}$ & 6.6884 & 10.167 & 1.2408 & 12.422 & 1.434 & $12.633^{a}$ & 0.0053 & $0 \%$ & $54 \%$ & $99 \%$ \\
\hline $\begin{array}{l}\text { AcPh + (R)- } \\
\text { ADH (28h) }\end{array}$ & 7.3108 & 10.163 & 1.2355 & 12.417 & 1.5381 & $12.63^{a}$ & 0.0537 & $0 \%$ & $54 \%$ & $93 \%$ \\
\hline $\begin{array}{l}\text { AcPh +(S)- } \\
\text { ADH (2h) }\end{array}$ & 3.9491 & 10.182 & 0.7368 & 12.443 & 0.0047 & $12.622^{\mathrm{a}}$ & 0.8103 & $0 \%$ & $52 \%$ & $99 \%$ \\
\hline $\begin{array}{l}\text { AcPh + (S)- } \\
\text { ADH (28h) }\end{array}$ & 6.5514 & 10.165 & 1.1978 & 12.438 & 0.0419 & $12.615^{a}$ & 1.1845 & $0 \%$ & $49 \%$ & $93 \%$ \\
\hline $\begin{array}{l}\text { ClAcPh + (R)- } \\
\text { ADH (2hrs) }\end{array}$ & 5.3995 & 13.047 & 0.7086 & 14.982 & 1.2275 & $15.137^{b}$ & 0.0054 & $0 \%$ & $63 \%$ & $99 \%$ \\
\hline $\begin{array}{c}\text { ClAcPh + (R)- } \\
\text { ADH }(28 h)\end{array}$ & 7.2288 & 13.045 & 0.7668 & 14.98 & 1.5585 & $15.137^{b}$ & 0.0703 & $0 \%$ & $65 \%$ & $91 \%$ \\
\hline $\begin{array}{c}\mathrm{ClAcPh}+(S)- \\
\text { ADH (2h) }\end{array}$ & 7.4903 & 13.043 & 1.1225 & 14.995 & 0.0119 & $15.122^{b}$ & 1.7392 & $0 \%$ & $61 \%$ & $99 \%$ \\
\hline $\begin{array}{l}\text { ClAcPh + (S)- } \\
\text { ADH }(28 h)\end{array}$ & 6.0722 & 13.043 & 0.6968 & 14.993 & 0.0552 & $15.125^{b}$ & 1.0554 & $0 \%$ & $58 \%$ & $90 \%$ \\
\hline $\begin{array}{c}\mathrm{BrAcPh}+(R)- \\
\mathrm{ADH}(2 \mathrm{~h}) \\
\end{array}$ & 5.0468 & 14.362 & 0.7005 & $15.668^{c}$ & 1.1376 & 15.798 & 0.0034 & $0 \%$ & $62 \%$ & $99 \%$ \\
\hline $\begin{array}{c}\mathrm{BrAcPh}+(R)- \\
\mathrm{ADH}(28 \mathrm{~h})\end{array}$ & 6.6892 & 14.36 & 0.7324 & $15.667^{c}$ & 1.5132 & 15.795 & 0.0563 & $0 \%$ & $66 \%$ & $93 \%$ \\
\hline $\begin{array}{c}\mathrm{BrAcPh}+(S)- \\
\mathrm{ADH}(2 \mathrm{~h})\end{array}$ & 4.8686 & 14.362 & 0.7127 & $15.682^{c}$ & 0.0109 & 15.785 & 1.1345 & $0 \%$ & $61 \%$ & $98 \%$ \\
\hline $\begin{array}{c}\text { BrAcPh + (S)- } \\
\text { ADH }(28 \mathrm{~h})\end{array}$ & 9.0587 & 14.355 & 1.0842 & $15.68^{c}$ & 0.1124 & 15.78 & 1.8713 & $0 \%$ & $61 \%$ & $89 \%$ \\
\hline $\begin{array}{c}\mathrm{IACPh}+(R)- \\
\text { ADH (2h) }\end{array}$ & 5.9736 & 15.547 & 0.411 & 16.557 & 0.9112 & 16.625 & 0.0017 & $0 \%$ & $69 \%$ & $>99 \%$ \\
\hline $\begin{array}{c}\text { IACPh + (R)- } \\
\text { ADH (28h) }\end{array}$ & 8.3244 & 15.532 & 2.6099 & 16.55 & 1.3783 & 16.667 & 0.0192 & $0 \%$ & $34 \%$ & $97 \%$ \\
\hline $\begin{array}{c}\text { IAcPh + (S)- } \\
\text { ADH (2h) }\end{array}$ & 5.4465 & 15.537 & 1.8618 & 16.568 & 0.0083 & 16.658 & 0.8038 & $0 \%$ & $30 \%$ & $98 \%$ \\
\hline $\begin{array}{l}\text { IAcPh + (S)- } \\
\text { ADH (28h) }\end{array}$ & 5.8249 & 15.543 & 0.4145 & 16.563 & 0.0366 & 16.658 & 0.7126 & $0 \%$ & $61 \%$ & $90 \%$ \\
\hline
\end{tabular}

${ }^{a}$ consistent with retention time reported for commercial product standard in previous work, $(S)$ product observed at $12.6 \mathrm{~min} .{ }^{1 \mathrm{~b}}$ consistent with retention time reported for commercial product standard in previous work, $(S)$-product observed at $15.1 \mathrm{~min} .{ }^{1}{ }^{\mathrm{c}}$ consistent with retention time reported for commercial product standard in previous work, $(R)$-product observed at $15.7 \mathrm{~min} .{ }^{1}$ 


\section{Reduction of 49 and 58 using $\mathrm{H}_{2}$-driven cofactor recycling}

Reduction of $\mathbf{4 9}$ and $\mathbf{5 8}$ was performed as described in the $\mathrm{H}_{2}$-driven cofactor recycling batch reductions general procedure, with the reaction mixtures as detailed below in Supplementary Figure 4. GC (Supplementary Figure 5) and ${ }^{1}$ H NMR (Supplementary Figure 6) was used to confirm reduction and calculate ee. We observed that the racemic product standard contained peaks roughly 0.1 min apart, with reductions of $\mathbf{4 9}$ giving an earlier peak with (R)-ADH and later peak with (S)-ADH, corresponding with those in the racemic product standard. This was consistent with our previous observations that reduction of acetophenone analogues results in a peak approximately $0.1 \mathrm{~min}$ later for the $(S)$-product and gave us confidence in our assignments.

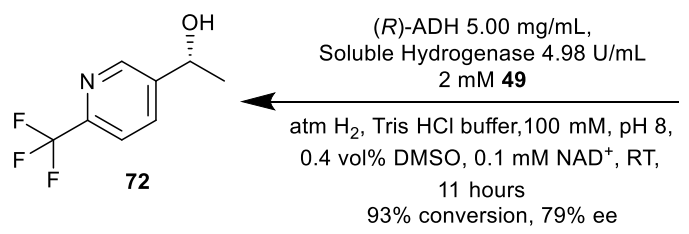<smiles>C[C@H](O)c1cccc(C#N)c1</smiles>

73
(R)-ADH $5.00 \mathrm{mg} / \mathrm{mL}$ Soluble Hydrogenase $4.98 \mathrm{U} / \mathrm{mL}$

atm $\mathrm{H}_{2}$, Tris $\mathrm{HCl}$ buffer, $50 \mathrm{mM}, \mathrm{pH} 8,0.4$ vol\% DMSO, $0.1 \mathrm{mM} \mathrm{NAD}^{+}, \mathrm{RT}$, 11 hours $71 \%$ conversion, $94 \%$ ee<smiles>CC(=O)c1ccc(C(F)(F)F)nc1</smiles>

\begin{tabular}{c} 
Soluble Hydrogenase $0.92 \mathrm{U} / \mathrm{mL}$ \\
$5 \mathrm{mM} 49$ \\
\hline atm $\mathrm{H}_{2}$, Tris $\mathrm{HCl}$ buffer, $100 \mathrm{mM}, \mathrm{pH} 8$, \\
1.0 vol\% DMSO, $0.1 \mathrm{mM} \mathrm{NAD}, \mathrm{RT}$, \\
18 hours \\
$99 \%$ conversion, $>99 \%$ ee
\end{tabular}<smiles>CC(=O)c1cccc(C#N)c1</smiles>

58
(S)-ADH $0.50 \mathrm{mg} / \mathrm{mL}$ Soluble Hydrogenase $1.38 \mathrm{U} / \mathrm{mL}$ atm $\mathrm{H}_{2}$, Tris $\mathrm{HCl}$ buffer, $50 \mathrm{mM}, \mathrm{pH} 8$, 0.4 vol\% DMSO, $0.1 \mathrm{mM} \mathrm{NAD}^{+}, \mathrm{RT}$, 7 hours

$99 \%$ conversion, $>99 \%$ ee<smiles>C[C@H](O)c1ccc(C(F)(F)F)nc1</smiles><smiles>C[C@@H](O)c1cccc(C#N)c1</smiles>

74

Supplementary Figure 4: Reaction compositions for the reduction of $\mathbf{4 9}$ and $\mathbf{5 8}$ using $\mathrm{H}_{2}$-driven cofactor recycling

\begin{tabular}{|c|c|c|c|c|c|c|c|c|c|}
\hline Reaction & $\begin{array}{c}\text { Undecan } \\
\text { e Peak } \\
\text { Area }\end{array}$ & $\begin{array}{l}\text { Retention } \\
\text { Time } \\
\text { Substrate } \\
\text { Peak/ min }\end{array}$ & $\begin{array}{c}\text { Area } \\
\text { Substrat } \\
\text { e Peak }\end{array}$ & $\begin{array}{l}\text { Retention } \\
\text { Time } \\
\text { R-Product } \\
\text { Peak/ min }\end{array}$ & $\begin{array}{l}\text { Area R- } \\
\text { Produc } \\
\text { t Peak }\end{array}$ & $\begin{array}{l}\text { Retention } \\
\text { Time } \\
\text { S-Product } \\
\text { Peak/ min }\end{array}$ & $\begin{array}{c}\text { Area S- } \\
\text { Product } \\
\text { Peak }\end{array}$ & $\begin{array}{c}\text { GC } \\
\text { Conversion }\end{array}$ & $\begin{array}{c}\text { Enantiomeric } \\
\text { Excess }\end{array}$ \\
\hline $\begin{array}{c}49+(R)-A D H \\
(11 \mathrm{~h})\end{array}$ & 6.9175 & 11.725 & 0.0812 & 15.018 & 1.0102 & 15.116 & 0.1104 & $93 \%$ & $80 \%$ \\
\hline $\begin{array}{c}49+(S)-A D H \\
(18 \mathrm{~h})\end{array}$ & 5.8377 & 11.728 & 0.0053 & - & - & 15.103 & 1.2171 & $99 \%$ & $>99 \%$ \\
\hline $\begin{array}{c}58+(R)-A D H \\
(11 \mathrm{~h})\end{array}$ & 5.9764 & 14.815 & 0.3039 & 16.475 & 0.7227 & 16.562 & 0.0205 & $71 \%$ & $94 \%$ \\
\hline $\begin{array}{c}58+(S)-A D H \\
(7 h)\end{array}$ & 6.2662 & 14.822 & 0.0040 & - & - & 16.552 & 0.9564 & $99 \%$ & $>99 \%$ \\
\hline
\end{tabular}




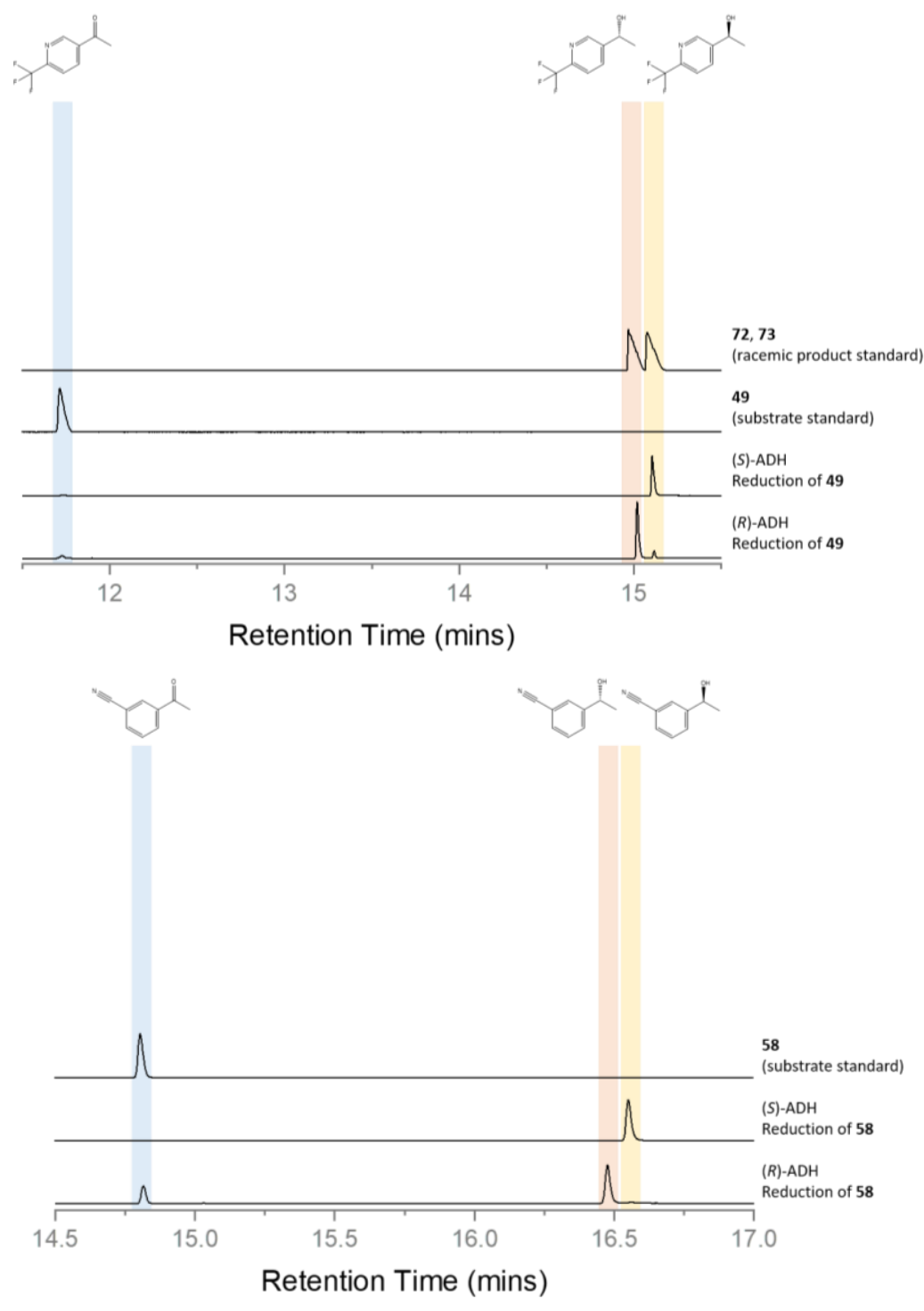

Supplementary Figure 5: Chiral GC FID data for the reduction of $\mathbf{4 9}$ and $\mathbf{5 8}$ 

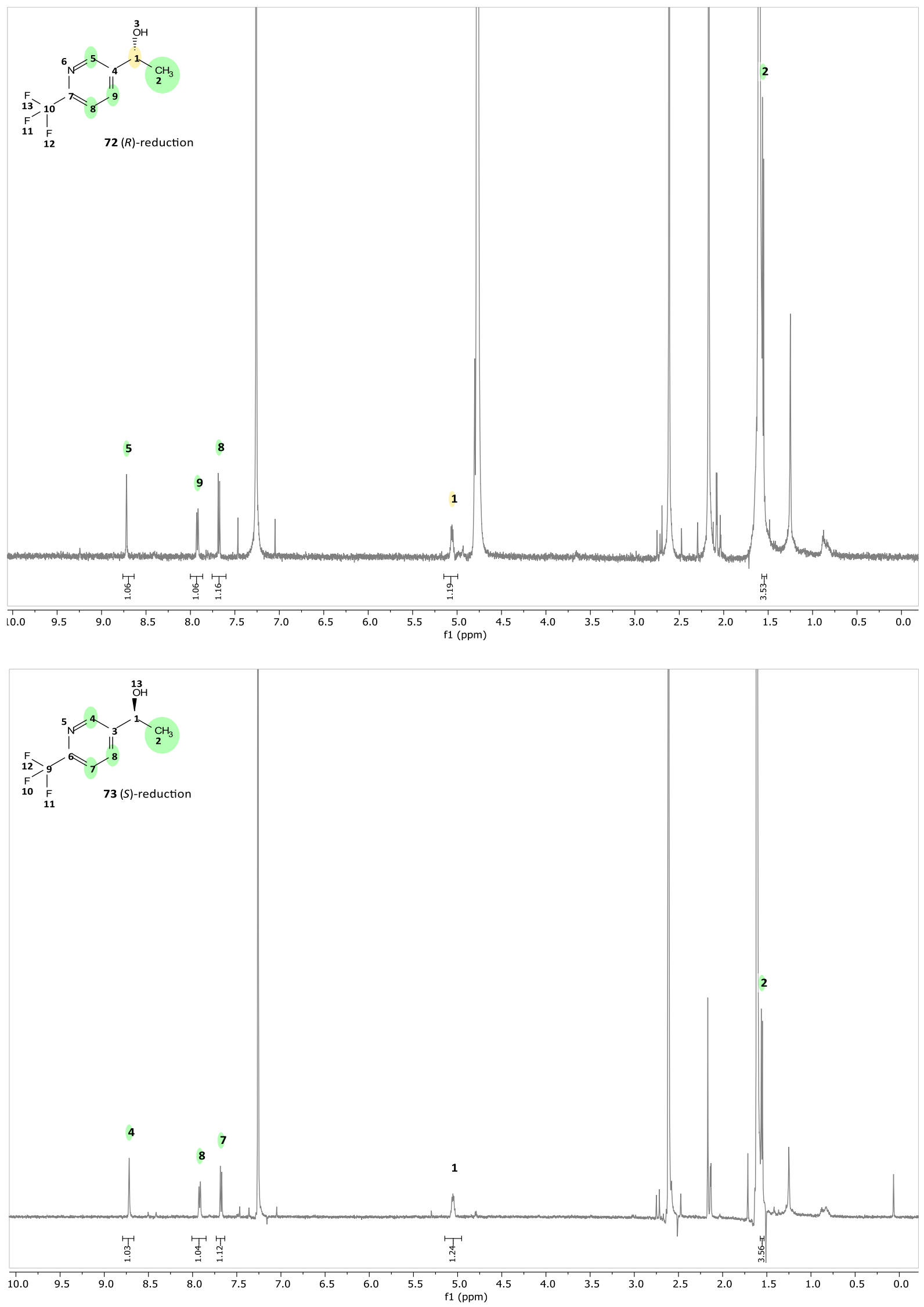

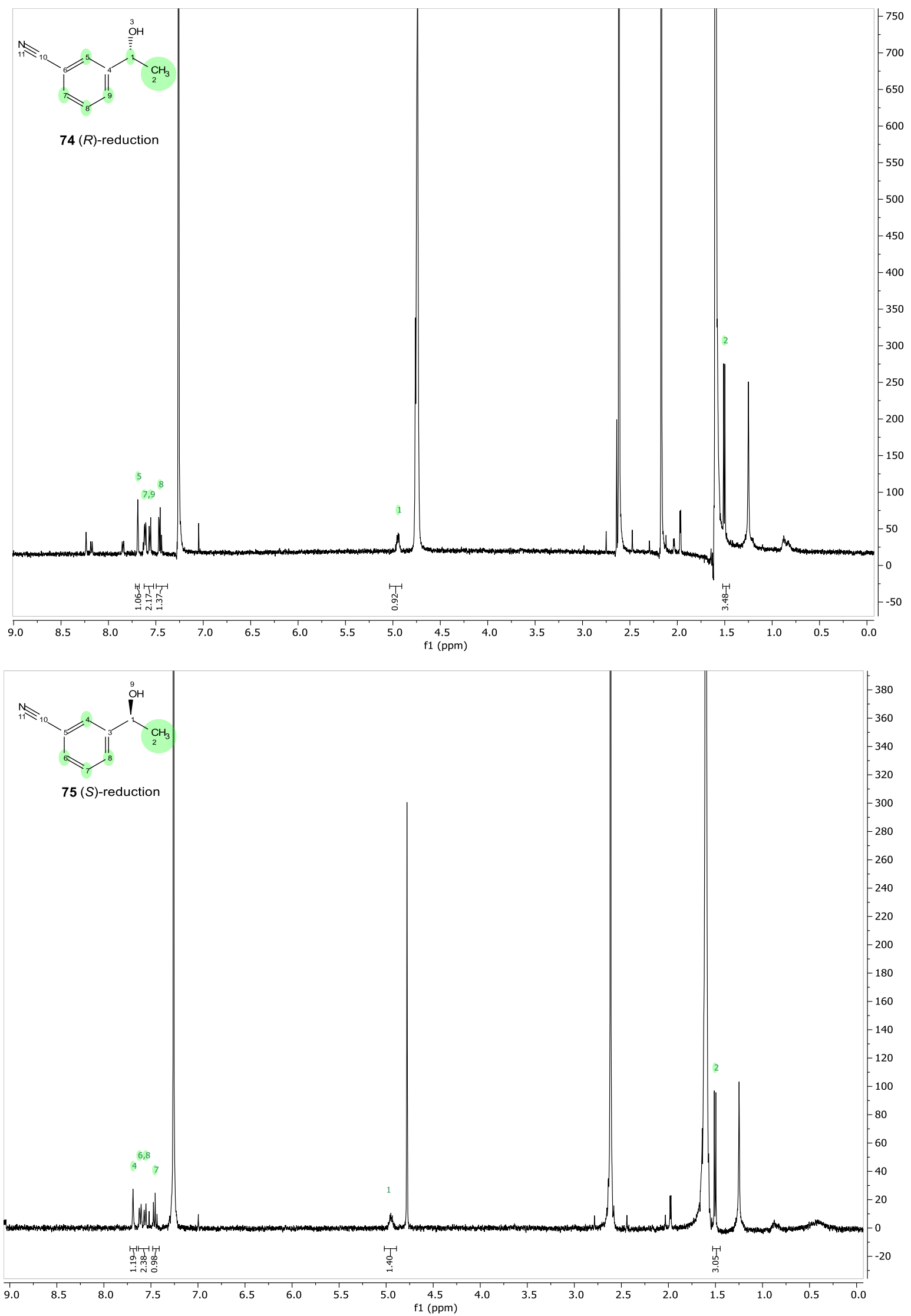

Supplementary Figure 6: ${ }^{1} \mathrm{H}$ NMR spectra for the reduction of $\mathbf{4 9}$ and $\mathbf{5 8}$ 


\section{NADPH consumption screening for new ADHs}

This screening followed the same protocol as for Tris $\mathrm{HCl}$ buffer $\mathrm{NADH}$ consumption screening, using ADHs 19, 20, 61 and 150, NADPH as the cofactor, and substrate concentrations of $10 \mathrm{mM}$ and 2.5 $\mathrm{mM}$. The reported SEA value is the higher value obtained out of the two concentrations.

\begin{tabular}{|c|c|c|c|c|c|c|c|c|}
\hline Compound & $\begin{array}{c}\text { Specific } \\
\text { Enzyme } \\
\text { Activity } \\
\text { ADH19/ nmol } \\
\mathrm{mg}^{-1} \mathrm{~min}^{-1}\end{array}$ & $\begin{array}{l}\text { Concentra } \\
\text { tion/ mM }\end{array}$ & $\begin{array}{c}\text { Specific } \\
\text { Enzyme } \\
\text { Activity } \\
\text { ADH20/ nmol } \\
\mathrm{mg}^{-1} \mathrm{~min}^{-1}\end{array}$ & $\begin{array}{l}\text { Concentra } \\
\text { tion/ mM }\end{array}$ & $\begin{array}{c}\text { Specific } \\
\text { Enzyme } \\
\text { Activity } \\
\text { ADH61/ } \\
\text { nmol mg-1 } \\
\text { min }^{-1} \\
\end{array}$ & $\begin{array}{l}\text { Concentra } \\
\text { tion/ mM }\end{array}$ & $\begin{array}{c}\text { Specific } \\
\text { Enzyme } \\
\text { Activity } \\
\text { ADH150/ } \\
\text { nmol mg } \\
\text { min }^{-1} \\
\end{array}$ & $\begin{array}{l}\text { Concentra } \\
\text { tion/ } \mathrm{mM}\end{array}$ \\
\hline 69 & 10.4 & 10 & 18.8 & 2.5 & 29.0 & 10 & 6.55 & 10 \\
\hline 18 & 6.78 & 2.5 & 67.2 & 2.5 & - & - & 38.6 & 2.5 \\
\hline 68 & 7.76 & 2.5 & 55.7 & 10 & 123 & 10 & 33.7 & 2.5 \\
\hline 34 & 14.3 & 2.5 & 31.3 & 2.5 & 56.4 & 2.5 & 7.83 & 2.5 \\
\hline 28 & - & - & 41.1 & 2.5 & - & - & 69.9 & 2.5 \\
\hline 55 & 12.8 & 2.5 & - & - & 12.7 & 2.5 & - & - \\
\hline 6 & 45.6 & 10 & - & - & 50.8 & 10 & - & - \\
\hline
\end{tabular}

\section{Screening tool development}

Rationale

With the sequence of the commercial enzymes used within this study not publically available, our approach was to build a screening tool which could predict substrate reactivity naive of the enzyme active site. To do this we applied Cresset's Forge software, which was originally developed as a drug discovery solution to allow for pharmacological modelling (modelling bioactivity naïve of the structure of the enzyme being targeted), based on the nature of the active molecules themselves in terms of electronic fields and molecule alignments. Our rationale was that the principles to model the reactivity of a substrate with a given enzyme should be analogous to those governing bioactivity of a ligand in a biologically relevant enzyme. By modelling NADH consumption activity values and conformational alignments of the substrates, we hoped to generate a model of reactivity analogous to a Quantitative Structure Activity Relationship (QSAR) and use this to generate a predictive screening tool to indicate the likely reactivity of a substrate with a specific ADH. We envisioned this would greatly help the synthetic chemist evaluate the potential utility of the ADH enzyme in question for their intended reduction.

Structures and compound identifiers

Substrates were imported in Forge as .mol files, with their lowest energy conformations generated in Chem3D. The identifiers as used in Forge for each compound were as follows:

\begin{tabular}{|c|c|}
\hline Compound & Molecule title in Forge \\
\hline $\mathbf{1}$ & Substrate $31: 1$ \\
\hline $\mathbf{2}$ & Substrate $3: 1$ \\
\hline $\mathbf{3}$ & Substrate $4: 1$ \\
\hline $\mathbf{4}$ & Substrate $39: 1$ \\
\hline $\mathbf{5}$ & Substrate $25: 1$ \\
\hline $\mathbf{6}$ & Substrate $2: 1$ \\
\hline $\mathbf{7}$ & Substrate $34: 1$ \\
\hline $\mathbf{8}$ & Substrate $1: 1$ \\
\hline $\mathbf{9}$ & Substrate $8: 1$ \\
\hline $\mathbf{1 0}$ & Substrate $10: 1$ \\
\hline $\mathbf{1 1}$ & Substrate $15: 1$ \\
\hline
\end{tabular}




\begin{tabular}{|c|c|}
\hline Compound & Molecule title in Forge \\
\hline 12 & Substrate 16:1 \\
\hline 13 & Substrate $12: 1$ \\
\hline 14 & Substrate 11:1 \\
\hline 15 & Substrate $5: 1$ \\
\hline 16 & Substrate $6: 1$ \\
\hline 17 & Substrate $7: 1$ \\
\hline 18 & Substrate $33: 1$ \\
\hline 19 & Substrate 9:1 \\
\hline 20 & Substrate $13: 1$ \\
\hline 21 & Substrate $23: 1$ \\
\hline 22 & Substrate 17:1 \\
\hline 23 & Substrate 19:1 \\
\hline 24 & Substrate $32: 1$ \\
\hline 25 & Substrate $36: 1$ \\
\hline 25 & Substrate $35: 1$ \\
\hline 26 & Substrate $22: 1$ \\
\hline 27 & Substrate $28: 1$ \\
\hline 28 & Substrate 29:1 \\
\hline 29 & Substrate $24: 1$ \\
\hline 30 & Substrate $37: 1$ \\
\hline 31 & Substrate $26: 1$ \\
\hline 32 & Substrate $27: 1$ \\
\hline 33 & Substrate G:1 \\
\hline 34 & Substrate $14: 1$ \\
\hline 36 & Substrate $30: 1$ \\
\hline 37 & Substrate F:1 \\
\hline 38 & Substrate C:1 \\
\hline 40 & Substrate D:1 \\
\hline 45 & Substrate AC:1 \\
\hline 47 & Substrate R:1 \\
\hline 48 & Substrate $\mathrm{P}: 1$ \\
\hline 49 & Substrate L:1 \\
\hline 50 & Substrate $\mathrm{AH}: 1$ \\
\hline 51 & Substrate $18: 1$ \\
\hline 52 & Substrate $20: 1$ \\
\hline 53 & Substrate J:1 \\
\hline 54 & Substrate $21: 1$ \\
\hline 55 & Substrate S:1 \\
\hline 56 & Substrate I:1 \\
\hline 57 & Substrate M:1 \\
\hline 58 & Substrate N:1 \\
\hline 59 & Substrate AJ:1 \\
\hline 60 & Substrate AG:1 \\
\hline 61 & Substrate 0:1 \\
\hline 62 & Substrate Z:1 \\
\hline 63 & Substrate AA:1 \\
\hline 64 & Substrate AB:1 \\
\hline 66 & Substrate AD:1 \\
\hline 67 & Substrate Al:1 \\
\hline 68 & Substrate $\mathrm{Y}: 1$ \\
\hline 69 & Substrate K:1 \\
\hline 70 & Substrate AF:1 \\
\hline 71 & Substrate AE:1 \\
\hline
\end{tabular}

Imported activity values

Specific Enzyme Activity values for NADH consumption were imported into Forge as a .csv file. Inactive substrates were given the SEA value 0 mUnits. 


\begin{tabular}{|c|c|}
\hline Substrate & $\begin{array}{l}\text { Specific Enzyme } \\
\text { Activity } \\
\text { (S)-ADH/ mUnits }\end{array}$ \\
\hline acetophenone:1 & 99.1 \\
\hline Substrate $2: 1$ & 31.5 \\
\hline Substrate $3: 1$ & 122.1 \\
\hline Substrate $4: 1$ & 141.6 \\
\hline Substrate $8: 1$ & 27.2 \\
\hline Substrate $13: 1$ & 593.1 \\
\hline Substrate $14: 1$ & 36 \\
\hline Substrate $16: 1$ & 89.9 \\
\hline Substrate $17: 1$ & 162.6 \\
\hline Substrate $18: 1$ & 50.5 \\
\hline Substrate 19:1 & 136.6 \\
\hline Substrate $20: 1$ & 185.1 \\
\hline Substrate $21: 1$ & 0 \\
\hline Substrate 22:1 & 29.4 \\
\hline Substrate $23: 1$ & 57.3 \\
\hline Substrate $24: 1$ & 111.7 \\
\hline Substrate $26: 1$ & 239.4 \\
\hline Substrate $27: 1$ & 364 \\
\hline Substrate $28: 1$ & 337.2 \\
\hline Substrate 29:1 & 14.3 \\
\hline Substrate $30: 1$ & 37.1 \\
\hline Substrate $31: 1$ & 99.1 \\
\hline Substrate 32:1 & 92 \\
\hline Substrate 33:1 & 17.4 \\
\hline Substrate $35: 1$ & 60.3 \\
\hline Substrate $36: 1$ & 111.6 \\
\hline Substrate $37: 1$ & 54 \\
\hline Substrate $38: 1$ & 0 \\
\hline Substrate 39:1 & 39.5 \\
\hline Substrate C:1 & 0 \\
\hline Substrate D:1 & 0 \\
\hline Substrate F:1 & 23.4 \\
\hline Substrate G:1 & 62.1 \\
\hline Substrate I:1 & 20.7 \\
\hline Substrate J:1 & 229.2 \\
\hline Substrate K:1 & 62.2 \\
\hline Substrate L:1 & 210.2 \\
\hline Substrate M:1 & 203.3 \\
\hline Substrate N:1 & 173.4 \\
\hline Substrate 0:1 & 396.7 \\
\hline Substrate R:1 & 21.7 \\
\hline Substrate S:1 & 20.7 \\
\hline Substrate $P: 1$ & 0 \\
\hline Substrate 9:1 & 80.4 \\
\hline
\end{tabular}




\begin{tabular}{|c|c|}
\hline Substrate $10: 1$ & 83 \\
\hline Substrate $11: 1$ & 188.5 \\
\hline Substrate $12: 1$ & 195.8 \\
\hline Substrate $15: 1$ & 64 \\
\hline Substrate $25: 1$ & 158.2 \\
\hline Substrate $34: 1$ & 0 \\
\hline Substrate $1: 1$ & 156.6 \\
\hline Substrate $5: 1$ & 0 \\
\hline Substrate $6: 1$ & 242.4 \\
\hline Substrate $7: 1$ & 366 \\
\hline Substrate $\mathrm{Y}: 1$ & 34.6 \\
\hline Substrate $\mathrm{Z}: 1$ & 222.1 \\
\hline Substrate AA:1 & 220 \\
\hline Substrate AB:1 & 362.6 \\
\hline Substrate AC:1 & 0 \\
\hline Substrate AD:1 & 0 \\
\hline Substrate AE:1 & 98.2 \\
\hline Substrate AF:1 & 218.3 \\
\hline Substrate AG:1 & 87 \\
\hline Substrate AH:1 & 268.7 \\
\hline Substrate AI:1 & 0 \\
\hline Substrate AJ:1 & 116.9 \\
\hline
\end{tabular}

Reference generation using FieldTemplater

Method

Molecules selected for generating a pharmacophore-based reference in FieldTemplater were selected from those displaying a high specific enzyme activity, but being as structurally different as possible. 


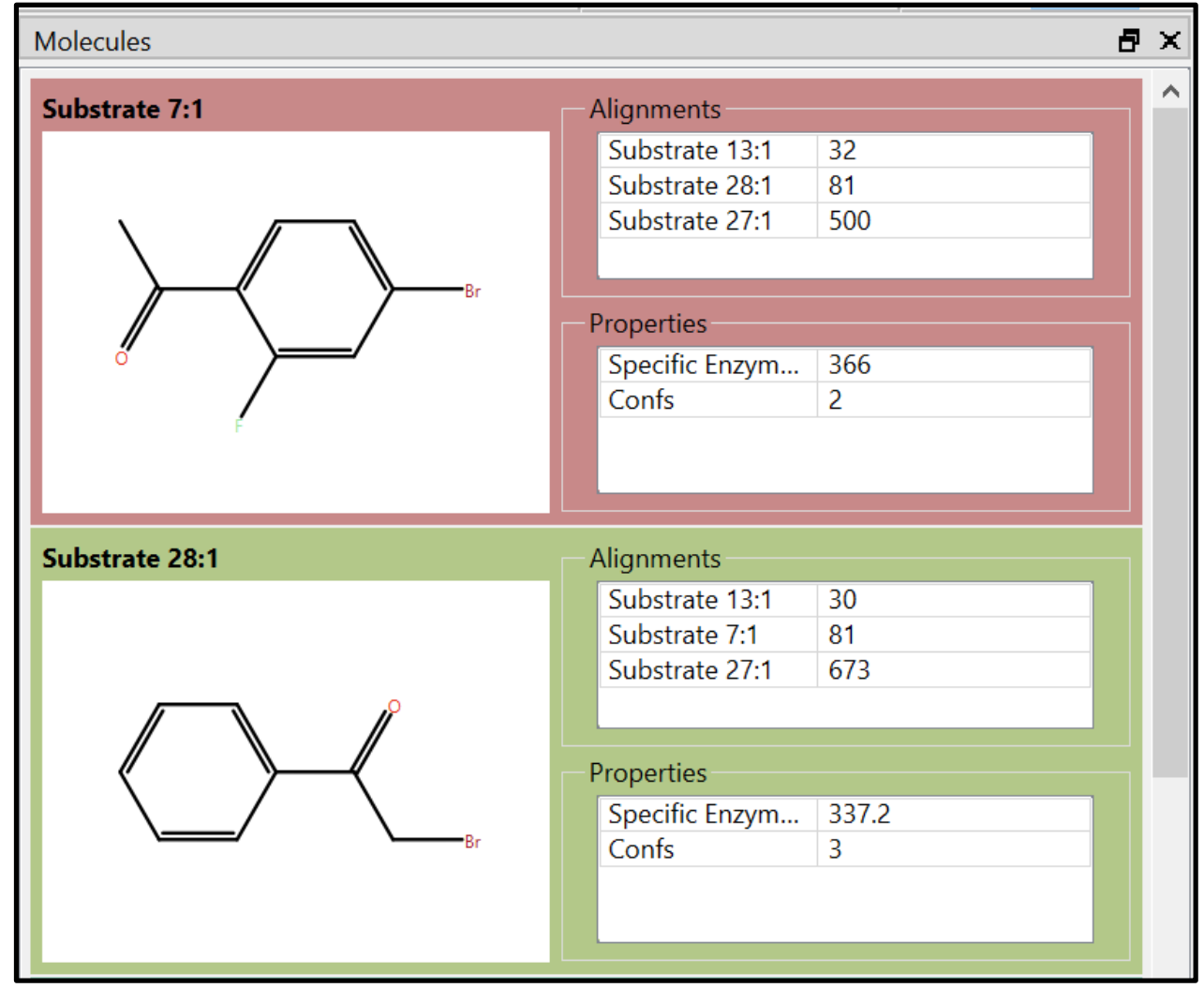

Log for molecule 'Substrate $7: 1$ '

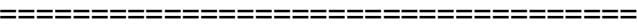

Molecule 'Substrate 7:1' read from file 'Q:/Kate/Modelling/Training set hexane tris water/Substrate 7.mol'

New conformation hunt process started at Sun Mar 29 14:07:06 2020

Conformation hunt settings for molecule 'Substrate 7:1'

Process config '[Custom]'

Acyclic secondary amide handling: Force trans

Add field points to conformations: true

Bypass RMS filter on rotatable bond twist of: 90

Dielectric: 2

Filter duplicate conformers at RMS: 0.5

Generate conformational enantiomers: true

Gradient cutoff for conformer minimization: 0.1

Keep conformations within an energy window of: 3

Maximum no. of chiral centres to enumerate: 4

Maximum number of conformations: 200

No. of high-T dynamics runs for flexible rings: 5

Number of bond randomisations: 300

Perform the conformation hunt: true

Perform the conformation hunt using an external tool: false

Process proto-confs in random order: true

Remove conformations containing boat and twistboat rings: false

Turn off Coulombic and attractive vdW forces: true

Use ring conformation library: true

A total of 2 confs were generated.

Conformation energies:

12.2313 .05

Aligning to molecule Substrate 13:1 using settings 'Normal'.

Aligning to molecule Substrate 28:1 using settings 'Normal'.

Aligning to molecule Substrate 27:1 using settings 'Normal'. 
Log for molecule 'Substrate 28:1'

Molecule 'Substrate 28:1' read from file 'Q:/Kate/Modelling/Training set hexane tris water/Substrate 28.mol'

New conformation hunt process started at Sun Mar 29 14:07:06 2020

Conformation hunt settings for molecule 'Substrate 28:1'

$==================+$
Process config '[Custom]'

Acyclic secondary amide handling: Force trans

Add field points to conformations: true

Bypass RMS filter on rotatable bond twist of: 90

Dielectric: 2

Filter duplicate conformers at RMS: 0.5

Generate conformational enantiomers: true

Gradient cutoff for conformer minimization: 0.1

Keep conformations within an energy window of: 3

Maximum no. of chiral centres to enumerate: 4

Maximum number of conformations: 200

No. of high-T dynamics runs for flexible rings: 5

Number of bond randomisations: 300

Perform the conformation hunt: true

Perform the conformation hunt using an external tool: false

Process proto-confs in random order: true

Remove conformations containing boat and twistboat rings: false

Turn off Coulombic and attractive vdW forces: true

Use ring conformation library: true

A total of 3 confs were generated.

Conformation energies:

11.4311 .4312 .19

Aligning to molecule Substrate 7:1 using settings 'Normal'.

Aligning to molecule Substrate 13:1 using settings 'Normal'.

Aligning to molecule Substrate 27:1 using settings 'Normal'. 


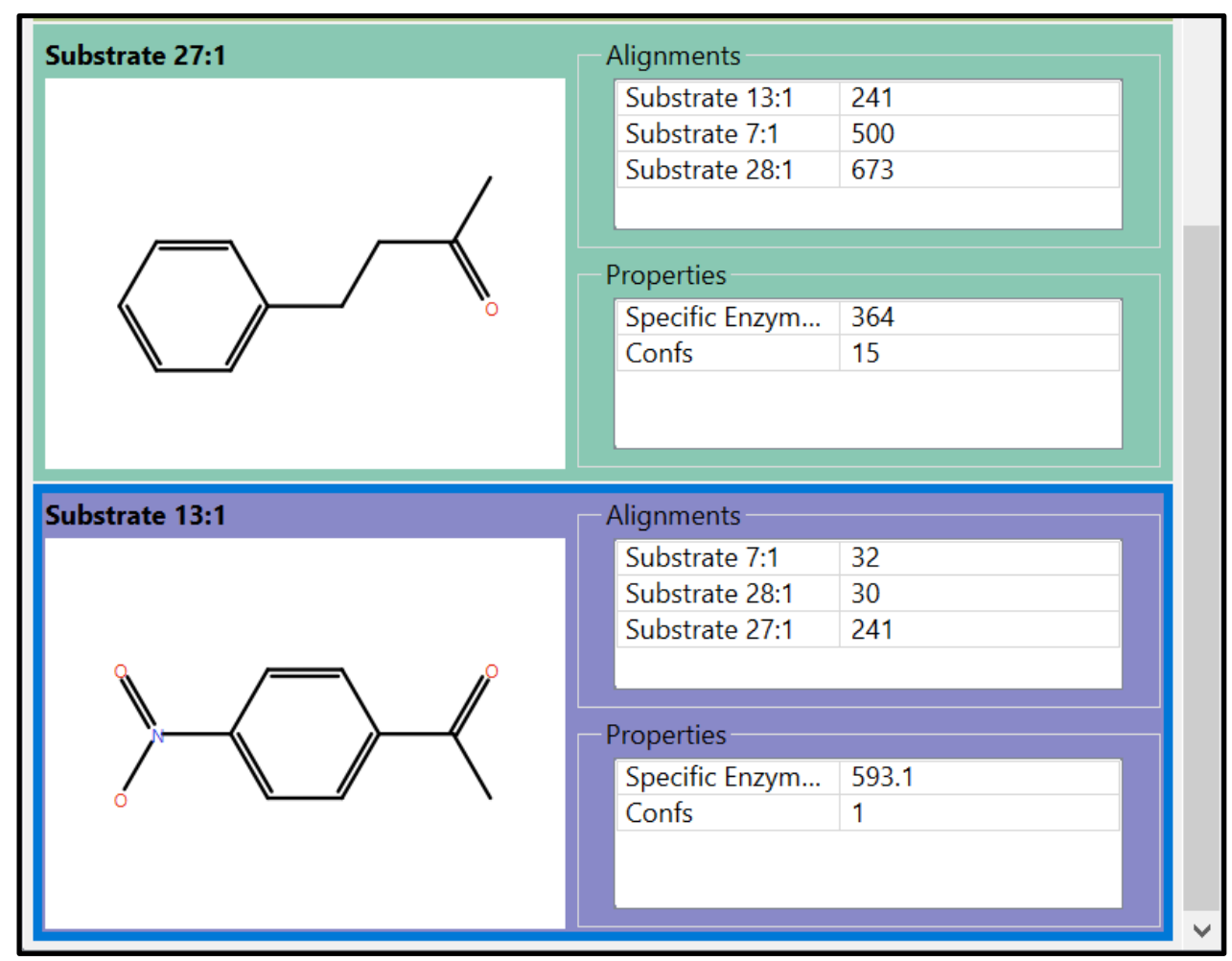

Log for molecule 'Substrate 27:1'

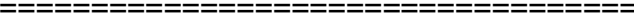

Molecule 'Substrate 27:1' read from file 'Q:/Kate/Modelling/Training set hexane tris water/Substrate 27.mol'

New conformation hunt process started at Sun Mar 29 14:07:06 2020

Conformation hunt settings for molecule 'Substrate 27:1'

Process config '[Custom]'

Acyclic secondary amide handling: Force trans

Add field points to conformations: true

Bypass RMS filter on rotatable bond twist of: 90

Dielectric: 2

Filter duplicate conformers at RMS: 0.5

Generate conformational enantiomers: true

Gradient cutoff for conformer minimization: 0.1

Keep conformations within an energy window of: 3

Maximum no. of chiral centres to enumerate: 4

Maximum number of conformations: 200

No. of high-T dynamics runs for flexible rings: 5

Number of bond randomisations: 300

Perform the conformation hunt: true

Perform the conformation hunt using an external tool: false

Process proto-confs in random order: true

Remove conformations containing boat and twistboat rings: false

Turn off Coulombic and attractive vdW forces: true

Use ring conformation library: true

A total of 15 confs were generated.

Conformation energies:

10.6010 .8910 .8911 .0911 .0911 .8611 .8612 .62

12.6212 .8112 .8113 .0113 .0113 .7313 .73

Aligning to molecule Substrate 7:1 using settings 'Normal'.

Aligning to molecule Substrate $28: 1$ using settings 'Normal'.

Aligning to molecule Substrate 13:1 using settings 'Normal'.

Log for molecule 'Substrate 13:1'

$==============================$ 
Molecule 'Substrate 13:1' read from file 'Q:/Kate/Modelling/Training set hexane tris water/Substrate 13.mol'

New conformation hunt process started at Sun Mar 29 14:07:06 2020

Conformation hunt settings for molecule 'Substrate 13:1'

Process config '[Custom]'

Acyclic secondary amide handling: Force trans

Add field points to conformations: true

Bypass RMS filter on rotatable bond twist of: 90

Dielectric: 2

Filter duplicate conformers at RMS: 0.5

Generate conformational enantiomers: true

Gradient cutoff for conformer minimization: 0.1

Keep conformations within an energy window of: 3

Maximum no. of chiral centres to enumerate: 4

Maximum number of conformations: 200

No. of high-T dynamics runs for flexible rings: 5

Number of bond randomisations: 300

Perform the conformation hunt: true

Perform the conformation hunt using an external tool: false

Process proto-confs in random order: true

Remove conformations containing boat and twistboat rings: false

Turn off Coulombic and attractive vdW forces: true

Use ring conformation library: true

A total of 1 confs were generated.

Conformation energies:

31.67

Aligning to molecule Substrate 7:1 using settings 'Normal'.

Aligning to molecule Substrate $28: 1$ using settings 'Normal'.

Aligning to molecule Substrate 27:1 using settings 'Normal'. 
Results
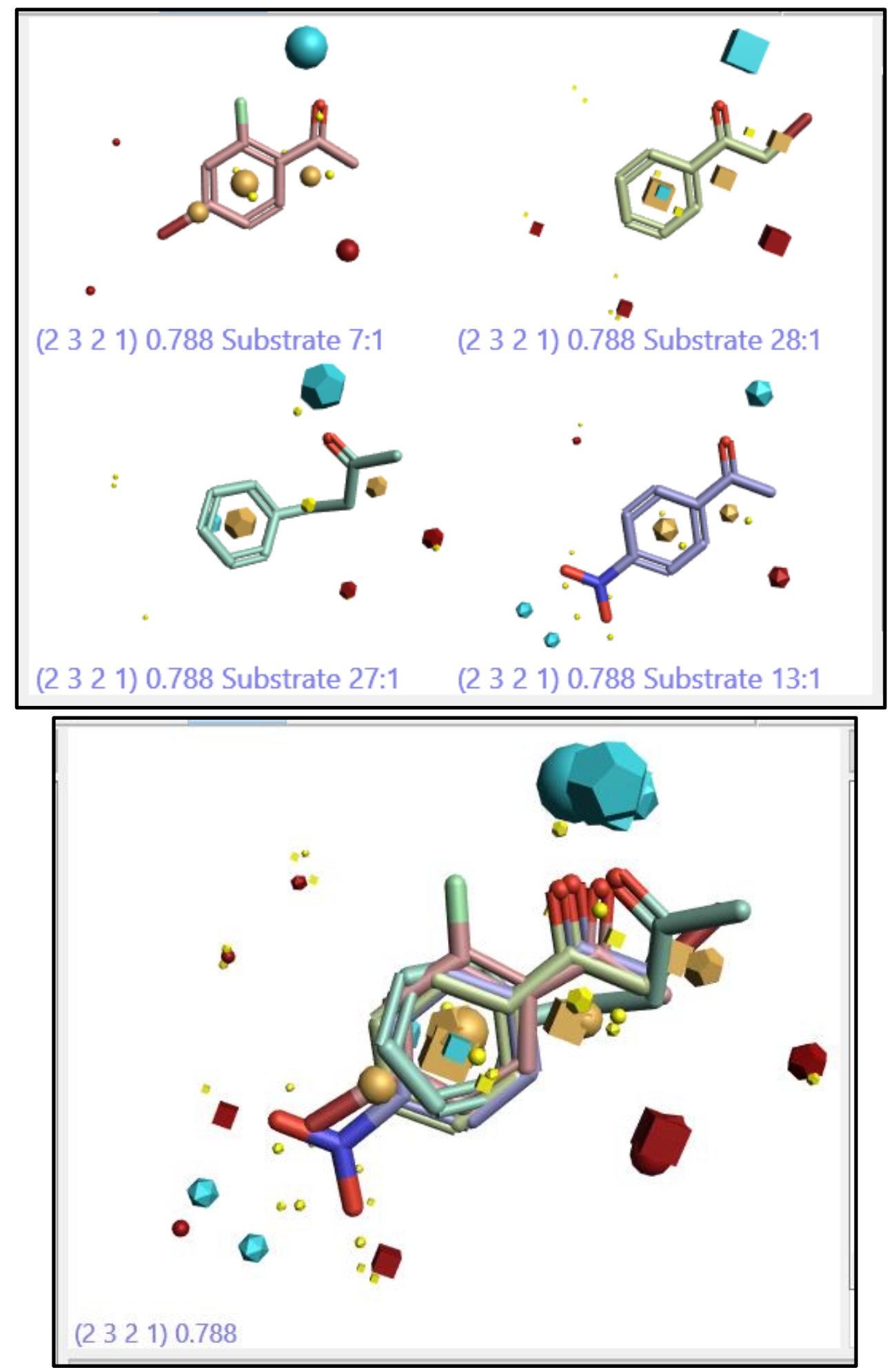


\begin{tabular}{|c|c|c|c|c|c|c|c|c|c|c|c|c|c|c|c|c|c|c|c|c|c|c|c|}
\hline $\begin{array}{c}\text { Templ } \\
\text { ate }\end{array}$ & $\begin{array}{c}\text { Isomer } \\
\text { Substra } \\
\text { te } 7: 1\end{array}$ & $\begin{array}{c}\text { Conf } \\
\text { Substra } \\
\text { te } 7: 1\end{array}$ & $\begin{array}{l}\text { Isomer } \\
\text { Substra } \\
\text { te 28:1 }\end{array}$ & \begin{tabular}{|c|} 
Conf \\
Substra \\
te $28: 1$
\end{tabular} & \begin{tabular}{|c|} 
Isomer \\
Substrat \\
e 27:1
\end{tabular} & \begin{tabular}{c|} 
Conf \\
Substra \\
te $27: 1$
\end{tabular} & \begin{tabular}{|l|} 
Isomer \\
Substra \\
te 13:1
\end{tabular} & \begin{tabular}{|c|} 
Conf \\
Substra \\
te $13: 1$
\end{tabular} & \begin{tabular}{|c|} 
Similarit \\
$y$
\end{tabular} & \begin{tabular}{|c|} 
Field \\
Similarit \\
$y$
\end{tabular} & $\begin{array}{l}\text { Raw } \\
\text { Field } \\
\text { Score }\end{array}$ & \begin{tabular}{|c|} 
Penalis \\
ed Field \\
Score
\end{tabular} & \begin{tabular}{|c|} 
Shape \\
Similarit \\
$y$
\end{tabular} & \begin{tabular}{|c|} 
Raw \\
Shape \\
Score
\end{tabular} & $\begin{array}{c}\text { Penali } \\
\text { sed } \\
\text { Shape } \\
\text { Score }\end{array}$ & \begin{tabular}{|c|} 
Tot \\
al \\
Pen \\
alty
\end{tabular} & \begin{tabular}{|c|} 
Exclud \\
ed \\
Volum \\
e \\
Clash \\
Penalt \\
y \\
\end{tabular} & \begin{tabular}{|c|} 
Atom \\
Distanc \\
e \\
Constrai \\
nt \\
Penalty \\
\end{tabular} & \begin{tabular}{|c|} 
Field \\
Value \\
Penalt \\
y \\
\end{tabular} & \begin{tabular}{|c|} 
Templat \\
e \\
Pairwis \\
e RMS \\
Similarit \\
y
\end{tabular} & $\begin{array}{c}\text { Templat } \\
\text { e RMS } \\
\text { Angle } \\
\text { Deviatio } \\
n\end{array}$ & \begin{tabular}{|c|} 
Templat \\
e RMS \\
Distanc \\
e \\
Deviatio \\
n
\end{tabular} & \begin{tabular}{|c|} 
Te \\
mpl \\
ate \\
Den \\
sity
\end{tabular} \\
\hline 1 & 1 & 2 & 1 & 3 & 1 & 2 & 1 & 1 & \begin{tabular}{|c|}
0.78770 \\
2
\end{tabular} & \begin{tabular}{|c|}
0.76679 \\
5 \\
\end{tabular} & $\begin{array}{c}- \\
40.4434 \\
\end{array}$ & $\begin{array}{c}- \\
40.4434 \\
\end{array}$ & $\begin{array}{c}0.80860 \\
9\end{array}$ & $\begin{array}{c}83.477 \\
4\end{array}$ & \begin{tabular}{|c|}
83.47 \\
74 \\
\end{tabular} & 0 & 0 & 0 & 0 & \begin{tabular}{|c|}
0.79102 \\
9
\end{tabular} & 3.73037 & \begin{tabular}{|c|}
0.11474 \\
4
\end{tabular} & 1 \\
\hline 2 & 1 & 2 & 1 & 3 & 1 & 4 & 1 & 1 & 0.78606 & \begin{tabular}{|c|}
0.75755 \\
1 \\
\end{tabular} & $\begin{array}{c}- \\
42.9015 \\
\end{array}$ & $\begin{array}{c}- \\
42.9015 \\
\end{array}$ & $\begin{array}{c}0.81456 \\
9\end{array}$ & $\begin{array}{c}84.091 \\
3\end{array}$ & $\begin{array}{c}84.09 \\
13 \\
\end{array}$ & 0 & 0 & 0 & 0 & $\begin{array}{c}0.78987 \\
6\end{array}$ & 3.1746 & 0.12006 & 1 \\
\hline 3 & 1 & 2 & 1 & 3 & 1 & 3 & 1 & 1 & \begin{tabular}{|c|}
0.78600 \\
6 \\
\end{tabular} & \begin{tabular}{|c|}
0.76234 \\
6 \\
\end{tabular} & \begin{tabular}{c|}
- \\
40.1652 \\
\end{tabular} & $\begin{array}{c}- \\
40.1652 \\
\end{array}$ & \begin{tabular}{|c|}
0.80966 \\
7 \\
\end{tabular} & $\begin{array}{c}83.587 \\
6 \\
\end{array}$ & \begin{tabular}{|c|}
83.58 \\
76 \\
\end{tabular} & 0 & 0 & 0 & 0 & \begin{tabular}{|c|}
0.78835 \\
6 \\
\end{tabular} & 3.73055 & \begin{tabular}{|c|}
0.11903 \\
2 \\
\end{tabular} & 1 \\
\hline 4 & 1 & 2 & 1 & 3 & 1 & 5 & 1 & 1 & \begin{tabular}{|c|}
0.78567 \\
9 \\
\end{tabular} & \begin{tabular}{|c|}
0.75797 \\
6 \\
\end{tabular} & $\begin{array}{c}- \\
42.7453 \\
\end{array}$ & $\begin{array}{c}- \\
42.7453 \\
\end{array}$ & $\begin{array}{c}0.81338 \\
1\end{array}$ & $\begin{array}{c}83.976 \\
9 \\
\end{array}$ & \begin{tabular}{|c|}
83.97 \\
69 \\
\end{tabular} & 0 & 0 & 0 & 0 & \begin{tabular}{|c|}
0.78866 \\
4
\end{tabular} & 3.87503 & $\begin{array}{c}0.13459 \\
6\end{array}$ & 1 \\
\hline 5 & 1 & 2 & 1 & 1 & 1 & 2 & 1 & 1 & \begin{tabular}{|c|}
0.78032 \\
2 \\
\end{tabular} & \begin{tabular}{|c|}
0.75385 \\
2 \\
\end{tabular} & \begin{tabular}{c|}
- \\
41.3972 \\
\end{tabular} & $\begin{array}{c}- \\
41.3972 \\
\end{array}$ & $\begin{array}{c}0.80679 \\
1 \\
\end{array}$ & $\begin{array}{c}83.294 \\
1 \\
\end{array}$ & \begin{tabular}{|c|}
83.29 \\
41 \\
\end{tabular} & 0 & 0 & 0 & 0 & \begin{tabular}{|c|}
0.78072 \\
5 \\
\end{tabular} & 4.58577 & $\begin{array}{c}0.10555 \\
6 \\
\end{array}$ & 1 \\
\hline 6 & 1 & 2 & 1 & 2 & 1 & 3 & 1 & 1 & \begin{tabular}{|c|}
0.77918 \\
1 \\
\end{tabular} & \begin{tabular}{|c|}
0.74934 \\
7 \\
\end{tabular} & $\begin{array}{c}- \\
40.5138 \\
\end{array}$ & $\begin{array}{c}- \\
40.5138 \\
\end{array}$ & \begin{tabular}{|c|}
0.80901 \\
5 \\
\end{tabular} & $\begin{array}{c}83.524 \\
6 \\
\end{array}$ & \begin{tabular}{|c|}
83.52 \\
46 \\
\end{tabular} & 0 & 0 & 0 & 0 & \begin{tabular}{|c|}
0.77655 \\
2 \\
\end{tabular} & 2.4159 & \begin{tabular}{|c|}
0.06324 \\
9
\end{tabular} & 1 \\
\hline 7 & 1 & 2 & 1 & 2 & 1 & 4 & 1 & 1 & \begin{tabular}{|c|}
0.77765 \\
3 \\
\end{tabular} & 0.74665 & \begin{tabular}{c|}
- \\
43.4127 \\
\end{tabular} & $\begin{array}{c}- \\
43.4127 \\
\end{array}$ & $\begin{array}{c}0.80865 \\
6 \\
\end{array}$ & \begin{tabular}{|c|}
83.491 \\
2 \\
\end{tabular} & \begin{tabular}{|c|}
83.49 \\
12 \\
\end{tabular} & 0 & 0 & 0 & 0 & \begin{tabular}{|c|}
0.77847 \\
3 \\
\end{tabular} & 3.34259 & \begin{tabular}{|c|}
0.10082 \\
2 \\
\end{tabular} & 1 \\
\hline 8 & 1 & 2 & 1 & 1 & 1 & 5 & 1 & 1 & \begin{tabular}{|c|}
0.77600 \\
7 \\
\end{tabular} & \begin{tabular}{|c|}
0.74136 \\
4
\end{tabular} & $\begin{array}{c}- \\
43.5073 \\
\end{array}$ & \begin{tabular}{|c|}
- \\
43.5073 \\
\end{tabular} & $\begin{array}{c}0.81065 \\
1 \\
\end{array}$ & $\begin{array}{c}83.694 \\
1\end{array}$ & \begin{tabular}{|c|}
83.69 \\
41
\end{tabular} & 0 & 0 & 0 & 0 & \begin{tabular}{|c|}
0.77910 \\
6
\end{tabular} & 4.37173 & $\begin{array}{c}0.14875 \\
6 \\
\end{array}$ & 1 \\
\hline 9 & 1 & 2 & 1 & 2 & 1 & 2 & 1 & 1 & \begin{tabular}{|c|}
0.77472 \\
7 \\
\end{tabular} & \begin{tabular}{|c|}
0.74379 \\
2 \\
\end{tabular} & \begin{tabular}{|l|}
-40.232 \\
\end{tabular} & \begin{tabular}{|l|}
-40.232 \\
\end{tabular} & \begin{tabular}{|c|}
0.80566 \\
3 \\
\end{tabular} & $\begin{array}{c}83.176 \\
1 \\
\end{array}$ & \begin{tabular}{|c|}
83.17 \\
61 \\
\end{tabular} & 0 & 0 & 0 & 0 & 0.77611 & 8.24494 & \begin{tabular}{|c|}
0.21722 \\
7 \\
\end{tabular} & 1 \\
\hline 10 & 1 & 1 & 1 & 3 & 1 & 3 & 1 & 1 & 0.77203 & \begin{tabular}{|c|}
0.72963 \\
9
\end{tabular} & \begin{tabular}{|c|}
- \\
38.7034 \\
\end{tabular} & $\begin{array}{c}- \\
38.7034 \\
\end{array}$ & $\begin{array}{c}0.81441 \\
9\end{array}$ & $\begin{array}{c}84.093 \\
1\end{array}$ & \begin{tabular}{|c|}
84.09 \\
31 \\
\end{tabular} & 0 & 0 & 0 & 0 & 0.77582 & 2.78238 & $\begin{array}{c}0.16252 \\
4\end{array}$ & 1 \\
\hline 11 & 1 & 2 & 1 & 1 & 1 & 3 & 1 & 1 & \begin{tabular}{|c|}
0.77152 \\
8 \\
\end{tabular} & \begin{tabular}{|c|}
0.73721 \\
3 \\
\end{tabular} & $\begin{array}{c}- \\
40.3883 \\
\end{array}$ & $\begin{array}{c}- \\
40.3883 \\
\end{array}$ & \begin{tabular}{|c|}
0.80584 \\
3 \\
\end{tabular} & $\begin{array}{c}83.187 \\
3 \\
\end{array}$ & \begin{tabular}{|c|}
83.18 \\
73 \\
\end{tabular} & 0 & 0 & 0 & 0 & \begin{tabular}{|c|}
0.77436 \\
9 \\
\end{tabular} & 6.80866 & \begin{tabular}{|c|}
0.18082 \\
3
\end{tabular} & 1 \\
\hline 12 & 1 & 1 & 1 & 3 & 1 & 2 & 1 & 1 & \begin{tabular}{|c|}
0.77058 \\
9 \\
\end{tabular} & \begin{tabular}{|c|}
0.72399 \\
6 \\
\end{tabular} & \begin{tabular}{|c|}
- \\
38.4557 \\
\end{tabular} & \begin{tabular}{|c|}
- \\
38.4557 \\
\end{tabular} & \begin{tabular}{|c|}
0.81718 \\
2 \\
\end{tabular} & $\begin{array}{c}84.372 \\
8 \\
\end{array}$ & \begin{tabular}{|c|}
84.37 \\
28 \\
\end{tabular} & 0 & 0 & 0 & 0 & \begin{tabular}{|c|}
0.77181 \\
4
\end{tabular} & 3.33889 & $\begin{array}{c}0.15238 \\
9 \\
\end{array}$ & 1 \\
\hline 13 & 1 & 1 & 1 & 3 & 1 & 4 & 1 & 1 & \begin{tabular}{|c|}
0.77050 \\
3 \\
\end{tabular} & 0.71951 & $\begin{array}{c}- \\
41.0275 \\
\end{array}$ & $\begin{array}{c}- \\
41.0275 \\
\end{array}$ & $\begin{array}{c}0.82149 \\
6\end{array}$ & $\begin{array}{c}84.825 \\
8\end{array}$ & \begin{tabular}{|c|}
84.82 \\
58 \\
\end{tabular} & 0 & 0 & 0 & 0 & \begin{tabular}{|c|}
0.77319 \\
1
\end{tabular} & 2.99743 & $\begin{array}{c}0.17165 \\
3\end{array}$ & 1 \\
\hline 14 & 1 & 1 & 1 & 3 & 1 & 5 & 1 & 1 & \begin{tabular}{|c|}
0.76985 \\
9 \\
\end{tabular} & \begin{tabular}{|c|}
0.71974 \\
4 \\
\end{tabular} & -40.863 & -40.863 & \begin{tabular}{|c|}
0.81997 \\
5 \\
\end{tabular} & $\begin{array}{c}84.668 \\
3 \\
\end{array}$ & \begin{tabular}{|c|}
84.66 \\
83 \\
\end{tabular} & 0 & 0 & 0 & 0 & \begin{tabular}{|c|}
0.77308 \\
4 \\
\end{tabular} & \begin{tabular}{|l|}
1.76724 \\
\end{tabular} & \begin{tabular}{|c|}
0.10413 \\
9
\end{tabular} & 1 \\
\hline 15 & 1 & 2 & 1 & 1 & 1 & 4 & 1 & 1 & \begin{tabular}{|c|}
0.76869 \\
5 \\
\end{tabular} & \begin{tabular}{|c|}
0.72582 \\
2 \\
\end{tabular} & \begin{tabular}{c|}
- \\
42.6498 \\
\end{tabular} & $\begin{array}{c}- \\
42.6498 \\
\end{array}$ & $\begin{array}{c}0.81156 \\
8 \\
\end{array}$ & $\begin{array}{c}83.792 \\
2 \\
\end{array}$ & \begin{tabular}{|c|}
83.79 \\
22 \\
\end{tabular} & 0 & 0 & 0 & 0 & \begin{tabular}{|c|}
0.77301 \\
5 \\
\end{tabular} & 6.89815 & \begin{tabular}{|c|}
0.13925 \\
2 \\
\end{tabular} & 1 \\
\hline 16 & 1 & 2 & 1 & 2 & 1 & 5 & 1 & 1 & \begin{tabular}{|c|}
0.76509 \\
8 \\
\end{tabular} & \begin{tabular}{|c|}
0.72148 \\
4 \\
\end{tabular} & \begin{tabular}{|c|}
- \\
41.6589 \\
\end{tabular} & $\begin{array}{c}- \\
41.6589 \\
\end{array}$ & \begin{tabular}{|c|}
0.80871 \\
2 \\
\end{tabular} & $\begin{array}{c}83.503 \\
3 \\
\end{array}$ & \begin{tabular}{|c|}
83.50 \\
33 \\
\end{tabular} & 0 & 0 & 0 & 0 & \begin{tabular}{|c|}
0.76983 \\
2 \\
\end{tabular} & 6.86491 & \begin{tabular}{|c|}
0.16441 \\
6 \\
\end{tabular} & 1 \\
\hline 17 & 1 & 2 & 1 & 3 & 1 & 8 & 1 & 1 & \begin{tabular}{|c|}
0.75639 \\
9 \\
\end{tabular} & \begin{tabular}{|c|}
0.70267 \\
3 \\
\end{tabular} & $\begin{array}{c}- \\
40.8484 \\
\end{array}$ & $\begin{array}{c}- \\
40.8484 \\
\end{array}$ & \begin{tabular}{|c|}
0.81012 \\
5 \\
\end{tabular} & $\begin{array}{c}83.619 \\
6 \\
\end{array}$ & \begin{tabular}{|c|}
83.61 \\
96 \\
\end{tabular} & 0 & 0 & 0 & 0 & \begin{tabular}{|c|}
0.78601 \\
4
\end{tabular} & 4.57015 & \begin{tabular}{|c|}
0.43354 \\
8 \\
\end{tabular} & 1 \\
\hline 18 & 1 & 2 & 1 & 2 & 1 & 7 & 1 & 1 & \begin{tabular}{|c|}
0.75515 \\
2 \\
\end{tabular} & \begin{tabular}{|c|}
0.67890 \\
4 \\
\end{tabular} & \begin{tabular}{|c|}
- \\
39.3827 \\
\end{tabular} & \begin{tabular}{|c|}
- \\
39.3827 \\
\end{tabular} & 0.8314 & $\begin{array}{c}85.823 \\
6\end{array}$ & \begin{tabular}{|c|}
85.82 \\
36 \\
\end{tabular} & 0 & 0 & 0 & 0 & \begin{tabular}{|c|}
0.75651 \\
3 \\
\end{tabular} & 2.72599 & \begin{tabular}{|c|}
0.06685 \\
2
\end{tabular} & 1 \\
\hline 19 & 1 & 2 & 1 & 3 & 1 & 9 & 1 & 1 & \begin{tabular}{|c|}
0.75392 \\
2 \\
\end{tabular} & \begin{tabular}{|c|}
0.69432 \\
9
\end{tabular} & \begin{tabular}{|c|}
- \\
39.9285 \\
\end{tabular} & $\begin{array}{c}- \\
39.9285 \\
\end{array}$ & \begin{tabular}{|c}
0.81351 \\
5 \\
\end{tabular} & $\begin{array}{c}83.976 \\
9\end{array}$ & \begin{tabular}{|c|}
83.97 \\
69
\end{tabular} & 0 & 0 & 0 & 0 & \begin{tabular}{|c|}
0.78124 \\
6
\end{tabular} & 8.67767 & \begin{tabular}{|c|}
0.44899 \\
2
\end{tabular} & 1 \\
\hline
\end{tabular}




\begin{tabular}{|c|c|c|c|c|c|c|c|c|c|c|c|c|c|c|c|c|c|c|c|c|c|c|c|}
\hline \begin{tabular}{|c|} 
Templ \\
ate
\end{tabular} & $\begin{array}{c}\text { Isomer } \\
\text { Substra } \\
\text { te } 7: 1\end{array}$ & $\begin{array}{c}\text { Conf } \\
\text { Substra } \\
\text { te } 7: 1\end{array}$ & $\begin{array}{l}\text { Isomer } \\
\text { Substra } \\
\text { te 28:1 }\end{array}$ & \begin{tabular}{|c|} 
Conf \\
Substra \\
te 28:1
\end{tabular} & \begin{tabular}{c|} 
Isomer \\
Substrat \\
e 27:1
\end{tabular} & \begin{tabular}{|c|} 
Conf \\
Substra \\
te 27:1
\end{tabular} & \begin{tabular}{|l|} 
Isomer \\
Substra \\
te 13:1
\end{tabular} & $\begin{array}{l}\text { Conf } \\
\text { Substra } \\
\text { te 13:1 }\end{array}$ & $\begin{array}{c}\text { Similarit } \\
y\end{array}$ & \begin{tabular}{|c} 
Field \\
Similarit \\
$y$
\end{tabular} & $\begin{array}{l}\text { Raw } \\
\text { Field } \\
\text { Score }\end{array}$ & \begin{tabular}{|c} 
Penalis \\
ed Field \\
Score
\end{tabular} & $\begin{array}{c}\text { Shape } \\
\text { Similarit } \\
y\end{array}$ & \begin{tabular}{|c|} 
Raw \\
Shape \\
Score \\
\end{tabular} & $\begin{array}{c}\text { Penali } \\
\text { sed } \\
\text { Shape } \\
\text { Score }\end{array}$ & \begin{tabular}{|c|} 
Tot \\
al \\
Pen \\
alty \\
\end{tabular} & \begin{tabular}{|c|} 
Exclud \\
ed \\
Volum \\
e \\
Clash \\
Penalt \\
y
\end{tabular} & \begin{tabular}{|c|} 
Atom \\
Distanc \\
e \\
Constrai \\
nt \\
Penalty \\
\end{tabular} & $\begin{array}{c}\text { Field } \\
\text { Value } \\
\text { Penalt } \\
y\end{array}$ & \begin{tabular}{|c|} 
Templat \\
e \\
Pairwis \\
e RMS \\
Similarit \\
y
\end{tabular} & \begin{tabular}{|c} 
Templat \\
e RMS \\
Angle \\
Deviatio \\
$\mathrm{n}$
\end{tabular} & \begin{tabular}{|c} 
Templat \\
e RMS \\
Distanc \\
e \\
Deviatio \\
$n$
\end{tabular} & \begin{tabular}{|l|} 
Te \\
mpl \\
ate \\
Den \\
sity
\end{tabular} \\
\hline 20 & 1 & 2 & 1 & 3 & 1 & 7 & 1 & 1 & $\begin{array}{c}0.74788 \\
5\end{array}$ & $\begin{array}{c}0.68253 \\
9\end{array}$ & $\begin{array}{c}- \\
38.5503\end{array}$ & $\begin{array}{c}- \\
38.5503 \\
\end{array}$ & \begin{tabular}{|c}
0.81323 \\
2
\end{tabular} & $\begin{array}{c}83.970 \\
5\end{array}$ & \begin{tabular}{|c|}
83.97 \\
05
\end{tabular} & 0 & 0 & 0 & 0 & \begin{tabular}{|c|}
0.69311 \\
1
\end{tabular} & \begin{tabular}{|l|l|}
4.04981 \\
\end{tabular} & $\begin{array}{c}0.10074 \\
4\end{array}$ & \begin{tabular}{|c|}
0.8 \\
333 \\
33
\end{tabular} \\
\hline 21 & 1 & 2 & 1 & 3 & 1 & 2 & 1 & 1 & $\begin{array}{c}0.74696 \\
1\end{array}$ & $\begin{array}{c}0.74738 \\
1\end{array}$ & $\begin{array}{c}- \\
39.3684\end{array}$ & $\begin{array}{c}- \\
39.3684\end{array}$ & $\begin{array}{c}0.74654 \\
2\end{array}$ & $\begin{array}{c}77.144 \\
3\end{array}$ & $\begin{array}{c}77.14 \\
43\end{array}$ & 0 & 0 & 0 & 0 & \begin{tabular}{|c|}
0.70009 \\
2
\end{tabular} & \begin{tabular}{|l}
5.88437 \\
\end{tabular} & $\begin{array}{c}0.19425 \\
8\end{array}$ & \begin{tabular}{|c|}
0.8 \\
333 \\
33
\end{tabular} \\
\hline 22 & 1 & 2 & 1 & 1 & 1 & 6 & 1 & 1 & $\begin{array}{c}0.74675 \\
5\end{array}$ & $\begin{array}{c}0.66188 \\
5\end{array}$ & $\begin{array}{c}- \\
39.1366\end{array}$ & \begin{tabular}{c|}
- \\
39.1366 \\
\end{tabular} & $\begin{array}{c}0.83162 \\
5\end{array}$ & $\begin{array}{c}85.850 \\
1\end{array}$ & $\begin{array}{c}85.85 \\
01\end{array}$ & 0 & 0 & 0 & 0 & \begin{tabular}{|c|}
0.64928 \\
7
\end{tabular} & 8.86666 & $\begin{array}{c}0.23069 \\
8\end{array}$ & $\begin{array}{c}0.6 \\
666 \\
67\end{array}$ \\
\hline 23 & 1 & 2 & 1 & 2 & 1 & 8 & 1 & 1 & $\begin{array}{c}0.74652 \\
5\end{array}$ & $\begin{array}{c}0.69633 \\
5\end{array}$ & $\begin{array}{c}- \\
41.4304\end{array}$ & $\begin{array}{c}- \\
41.4304\end{array}$ & $\begin{array}{c}0.79671 \\
4\end{array}$ & $\begin{array}{c}82.288 \\
8\end{array}$ & $\begin{array}{c}82.28 \\
88\end{array}$ & 0 & 0 & 0 & 0 & \begin{tabular}{|c|}
0.69784 \\
9
\end{tabular} & 5.09696 & $\begin{array}{c}0.39795 \\
6\end{array}$ & $\begin{array}{c}0.8 \\
333 \\
33\end{array}$ \\
\hline 24 & 1 & 2 & 1 & 1 & 1 & 9 & 1 & 1 & $\begin{array}{c}0.74578 \\
8\end{array}$ & $\begin{array}{c}0.68825 \\
2\end{array}$ & $\begin{array}{c}- \\
41.0681\end{array}$ & \begin{tabular}{c|}
- \\
41.0681
\end{tabular} & $\begin{array}{c}0.80332 \\
3\end{array}$ & $\begin{array}{c}82.941 \\
2\end{array}$ & \begin{tabular}{|c|}
82.94 \\
12
\end{tabular} & 0 & 0 & 0 & 0 & \begin{tabular}{|c|}
0.69437 \\
2
\end{tabular} & 5.3758 & $\begin{array}{c}0.31941 \\
5\end{array}$ & \begin{tabular}{|c|}
0.8 \\
333 \\
33 \\
\end{tabular} \\
\hline 25 & 1 & 2 & 1 & 3 & 1 & 6 & 1 & 1 & $\begin{array}{c}0.74478 \\
9\end{array}$ & $\begin{array}{c}0.67674 \\
2\end{array}$ & $\begin{array}{c}- \\
38.3892\end{array}$ & $\begin{array}{c}- \\
38.3892 \\
\end{array}$ & $\begin{array}{c}0.81283 \\
6\end{array}$ & $\begin{array}{c}83.929 \\
6\end{array}$ & \begin{tabular}{|c|}
83.92 \\
96
\end{tabular} & 0 & 0 & 0 & 0 & \begin{tabular}{|c|}
0.64701 \\
9
\end{tabular} & 5.08475 & $\begin{array}{c}0.21601 \\
3\end{array}$ & \begin{tabular}{|c}
0.6 \\
666 \\
67
\end{tabular} \\
\hline 26 & 1 & 2 & 1 & 3 & 1 & 4 & 1 & 1 & $\begin{array}{c}0.74338 \\
1\end{array}$ & 0.73322 & $\begin{array}{c}- \\
41.4942\end{array}$ & \begin{tabular}{c|}
- \\
41.4942
\end{tabular} & $\begin{array}{c}0.75354 \\
3\end{array}$ & $\begin{array}{c}77.866 \\
7\end{array}$ & $\begin{array}{c}77.86 \\
67\end{array}$ & 0 & 0 & 0 & 0 & \begin{tabular}{|c|}
0.69693 \\
7
\end{tabular} & 5.47889 & 0.07335 & \begin{tabular}{|c|}
0.8 \\
333 \\
33
\end{tabular} \\
\hline 27 & 1 & 1 & 1 & 3 & 1 & 8 & 1 & 1 & $\begin{array}{c}0.74329 \\
4\end{array}$ & $\begin{array}{c}0.66652 \\
9\end{array}$ & -38.943 & \begin{tabular}{|l|}
-38.943 \\
\end{tabular} & 0.82006 & $\begin{array}{c}84.679 \\
8\end{array}$ & $\begin{array}{c}84.67 \\
98\end{array}$ & 0 & 0 & 0 & 0 & 0.77688 & 4.01849 & $\begin{array}{c}0.53343 \\
8\end{array}$ & 1 \\
\hline 28 & 1 & 1 & 1 & 3 & 1 & 9 & 1 & 1 & 0.74294 & $\begin{array}{c}0.65775 \\
5\end{array}$ & $\begin{array}{c}- \\
38.0789\end{array}$ & $\begin{array}{c}- \\
38.0789 \\
\end{array}$ & \begin{tabular}{|c|}
0.82812 \\
5
\end{tabular} & $\begin{array}{c}85.504 \\
2\end{array}$ & $\begin{array}{c}85.50 \\
42\end{array}$ & 0 & 0 & 0 & 0 & \begin{tabular}{|c|}
0.76867 \\
8
\end{tabular} & \begin{tabular}{|l}
5.50698 \\
\end{tabular} & 0.47804 & 1 \\
\hline 29 & 1 & 2 & 1 & 3 & 1 & 3 & 1 & 1 & $\begin{array}{c}0.74280 \\
8\end{array}$ & $\begin{array}{c}0.73887 \\
1\end{array}$ & $\begin{array}{c}- \\
38.8697\end{array}$ & $\begin{array}{c}- \\
38.8697\end{array}$ & \begin{tabular}{|c|}
0.74674 \\
4
\end{tabular} & $\begin{array}{c}77.166 \\
4\end{array}$ & $\begin{array}{c}77.16 \\
64\end{array}$ & 0 & 0 & 0 & 0 & \begin{tabular}{|c|}
0.69664 \\
3
\end{tabular} & 8.46004 & $\begin{array}{c}0.18225 \\
2\end{array}$ & $\begin{array}{c}0.8 \\
333 \\
33\end{array}$ \\
\hline 30 & 1 & 2 & 1 & 3 & 1 & 1 & 1 & 1 & $\begin{array}{c}0.74164 \\
1\end{array}$ & $\begin{array}{c}0.67019 \\
2\end{array}$ & $\begin{array}{c}- \\
39.5989\end{array}$ & $\begin{array}{c}- \\
39.5989\end{array}$ & \begin{tabular}{|c|}
0.81309 \\
1
\end{tabular} & $\begin{array}{c}83.927 \\
1\end{array}$ & $\begin{array}{c}83.92 \\
71\end{array}$ & 0 & 0 & 0 & 0 & \begin{tabular}{|c|}
0.64976 \\
2
\end{tabular} & \begin{tabular}{|l|l|}
8.77954 \\
\end{tabular} & $\begin{array}{c}0.18578 \\
7\end{array}$ & \begin{tabular}{|c|}
0.6 \\
666 \\
67
\end{tabular} \\
\hline 31 & 1 & 2 & 1 & 2 & 1 & 9 & 1 & 1 & $\begin{array}{c}0.73790 \\
2\end{array}$ & $\begin{array}{c}0.67617 \\
5\end{array}$ & $\begin{array}{c}- \\
39.7979\end{array}$ & $\begin{array}{c}- \\
39.7979 \\
\end{array}$ & $\begin{array}{c}0.79962 \\
8\end{array}$ & $\begin{array}{c}82.566 \\
2\end{array}$ & $\begin{array}{c}82.56 \\
62\end{array}$ & 0 & 0 & 0 & 0 & \begin{tabular}{|c|}
0.69307 \\
1
\end{tabular} & 5.64458 & $\begin{array}{c}0.32569 \\
1\end{array}$ & \begin{tabular}{|c|}
0.8 \\
333 \\
33
\end{tabular} \\
\hline 32 & 1 & 2 & 1 & 1 & 1 & 8 & 1 & 1 & $\begin{array}{c}0.73788 \\
5\end{array}$ & $\begin{array}{c}0.69204 \\
2\end{array}$ & $\begin{array}{c}- \\
41.7454\end{array}$ & $\begin{array}{c}- \\
41.7454\end{array}$ & \begin{tabular}{|c|}
0.78372 \\
7
\end{tabular} & $\begin{array}{c}80.940 \\
5\end{array}$ & \begin{tabular}{|c|}
80.94 \\
05
\end{tabular} & 0 & 0 & 0 & 0 & \begin{tabular}{|c|}
0.69914 \\
1
\end{tabular} & 5.08048 & $\begin{array}{c}0.41352 \\
1\end{array}$ & \begin{tabular}{|c|}
0.8 \\
333 \\
33
\end{tabular} \\
\hline
\end{tabular}




\begin{tabular}{|c|c|c|c|c|c|c|c|c|c|c|c|c|c|c|c|c|c|c|c|c|c|c|c|}
\hline \begin{tabular}{|c|}
$\begin{array}{c}\text { Templ } \\
\text { ate }\end{array}$ \\
\end{tabular} & \begin{tabular}{|c|} 
Isomer \\
Substra \\
te 7:1
\end{tabular} & \begin{tabular}{|c|} 
Conf \\
Substra \\
te 7:1
\end{tabular} & \begin{tabular}{|l|} 
Isomer \\
Substra \\
te 28:1
\end{tabular} & \begin{tabular}{|c|} 
Conf \\
Substra \\
te 28:1
\end{tabular} & \begin{tabular}{|c|} 
Isomer \\
Substrat \\
e 27:1
\end{tabular} & \begin{tabular}{|c|} 
Conf \\
Substra \\
te 27:1
\end{tabular} & \begin{tabular}{|l|} 
Isomer \\
Substra \\
te 13:1
\end{tabular} & \begin{tabular}{|c|} 
Conf \\
Substra \\
te 13:1
\end{tabular} & $\begin{array}{c}\text { Similarit } \\
\mathrm{y}\end{array}$ & $\begin{array}{c}\text { Field } \\
\text { Similarit } \\
y\end{array}$ & $\begin{array}{l}\text { Raw } \\
\text { Field } \\
\text { Score }\end{array}$ & \begin{tabular}{|c|} 
Penalis \\
ed Field \\
Score
\end{tabular} & \begin{tabular}{|c|} 
Shape \\
Similarit \\
$y$
\end{tabular} & \begin{tabular}{|c|} 
Raw \\
Shape \\
Score \\
\end{tabular} & \begin{tabular}{|c|} 
Penali \\
sed \\
Shape \\
Score
\end{tabular} & \begin{tabular}{|c|} 
Tot \\
al \\
Pen \\
alty
\end{tabular} & \begin{tabular}{|c|} 
Exclud \\
ed \\
Volum \\
e \\
Clash \\
Penalt \\
y \\
\end{tabular} & \begin{tabular}{|c|} 
Atom \\
Distanc \\
e \\
Constrai \\
nt \\
Penalty \\
\end{tabular} & \begin{tabular}{|c|} 
Field \\
Value \\
Penalt \\
$y$
\end{tabular} & \begin{tabular}{|c|} 
Templat \\
e \\
Pairwis \\
e RMS \\
Similarit \\
y \\
\end{tabular} & \begin{tabular}{|c|} 
Templat \\
e RMS \\
Angle \\
Deviatio \\
$n$
\end{tabular} & \begin{tabular}{|c|} 
Templat \\
e RMS \\
Distanc \\
e \\
Deviatio \\
$n$
\end{tabular} & \begin{tabular}{|c|} 
Te \\
mpl \\
ate \\
Den \\
sity
\end{tabular} \\
\hline 33 & 1 & 1 & 1 & 3 & 1 & 9 & 1 & 1 & \begin{tabular}{|c|}
0.73738 \\
1
\end{tabular} & $\begin{array}{c}0.66507 \\
7\end{array}$ & \begin{tabular}{|c|}
- \\
38.4272 \\
\end{tabular} & $\begin{array}{c}- \\
38.4272 \\
\end{array}$ & $\begin{array}{c}0.80968 \\
4\end{array}$ & $\begin{array}{c}83.620 \\
2\end{array}$ & $\begin{array}{c}83.62 \\
02\end{array}$ & 0 & 0 & 0 & 0 & \begin{tabular}{|c|}
0.67237 \\
6
\end{tabular} & \begin{tabular}{|l|}
6.65704 \\
\end{tabular} & $\begin{array}{c}0.14793 \\
9\end{array}$ & \begin{tabular}{|c|}
0.8 \\
333 \\
33
\end{tabular} \\
\hline 34 & 1 & 2 & 1 & 2 & 1 & 11 & 1 & 1 & $\begin{array}{c}0.73353 \\
2\end{array}$ & 0.66379 & \begin{tabular}{|c|}
- \\
38.4331 \\
\end{tabular} & $\begin{array}{c}- \\
38.4331\end{array}$ & $\begin{array}{c}0.80327 \\
5\end{array}$ & $\begin{array}{c}82.938 \\
4\end{array}$ & \begin{tabular}{|c|}
82.93 \\
84
\end{tabular} & 0 & 0 & 0 & 0 & \begin{tabular}{|c|}
0.63293 \\
6
\end{tabular} & 8.19721 & $\begin{array}{c}0.17056 \\
7\end{array}$ & \begin{tabular}{|c|}
0.6 \\
666 \\
67 \\
\end{tabular} \\
\hline 35 & 1 & 2 & 1 & 1 & 1 & 2 & 1 & 1 & \begin{tabular}{|c|}
0.73349 \\
8
\end{tabular} & $\begin{array}{c}0.72987 \\
4\end{array}$ & \begin{tabular}{|c|}
- \\
39.9509 \\
\end{tabular} & $\begin{array}{c}- \\
39.9509 \\
\end{array}$ & \begin{tabular}{|c|}
0.73712 \\
2
\end{tabular} & $\begin{array}{c}76.195 \\
5\end{array}$ & $\begin{array}{c}76.19 \\
55\end{array}$ & 0 & 0 & 0 & 0 & 0.69178 & 6.00942 & \begin{tabular}{|c|}
0.21442 \\
5
\end{tabular} & \begin{tabular}{|c|}
0.8 \\
333 \\
33 \\
\end{tabular} \\
\hline 36 & 1 & 2 & 1 & 2 & 1 & 3 & 1 & 1 & \begin{tabular}{|c|}
0.73275 \\
7
\end{tabular} & $\begin{array}{c}0.72944 \\
9\end{array}$ & \begin{tabular}{|l|}
-39.34 \\
\end{tabular} & -39.34 & \begin{tabular}{|c|}
0.73606 \\
5
\end{tabular} & $\begin{array}{c}76.080 \\
5\end{array}$ & \begin{tabular}{|c|}
76.08 \\
05
\end{tabular} & 0 & 0 & 0 & 0 & \begin{tabular}{|c|}
0.68686 \\
1
\end{tabular} & 7.31339 & \begin{tabular}{|c|}
0.16916 \\
8
\end{tabular} & \begin{tabular}{|c|}
0.8 \\
333 \\
33
\end{tabular} \\
\hline 37 & 1 & 2 & 1 & 3 & 1 & 8 & 1 & 1 & $\begin{array}{c}0.73273 \\
4\end{array}$ & $\begin{array}{c}0.66778 \\
3\end{array}$ & \begin{tabular}{|c|}
- \\
38.5424 \\
\end{tabular} & $\begin{array}{c}- \\
38.5424\end{array}$ & \begin{tabular}{|c|}
0.79768 \\
4
\end{tabular} & 82.389 & \begin{tabular}{|c|}
82.38 \\
9
\end{tabular} & 0 & 0 & 0 & 0 & \begin{tabular}{|c|}
0.69207 \\
3
\end{tabular} & \begin{tabular}{|l|}
6.4797 \\
\end{tabular} & \begin{tabular}{|c|}
0.22289 \\
2
\end{tabular} & \begin{tabular}{|c|}
0.8 \\
333 \\
33 \\
\end{tabular} \\
\hline 38 & 1 & 2 & 1 & 2 & 1 & 4 & 1 & 1 & \begin{tabular}{|c|}
0.73178 \\
9
\end{tabular} & $\begin{array}{c}0.71771 \\
8\end{array}$ & \begin{tabular}{|c|}
- \\
41.6909 \\
\end{tabular} & $\begin{array}{c}- \\
1.6909\end{array}$ & \begin{tabular}{|c|}
0.74586 \\
1
\end{tabular} & $\begin{array}{c}77.093 \\
2\end{array}$ & \begin{tabular}{|c|}
77.09 \\
32
\end{tabular} & 0 & 0 & 0 & 0 & \begin{tabular}{|c|}
0.68758 \\
7
\end{tabular} & 5.96852 & \begin{tabular}{|c|}
0.08401 \\
2
\end{tabular} & \begin{tabular}{|c|}
0.8 \\
333 \\
33 \\
\end{tabular} \\
\hline 39 & 1 & 1 & 1 & 3 & 1 & 1 & 1 & 1 & \begin{tabular}{|c|}
0.73103 \\
2
\end{tabular} & 0.64852 & \begin{tabular}{|c|}
- \\
38.5293 \\
\end{tabular} & $\begin{array}{c}- \\
38.5293 \\
\end{array}$ & \begin{tabular}{|c|}
0.81354 \\
5 \\
\end{tabular} & $\begin{array}{c}83.995 \\
3\end{array}$ & \begin{tabular}{|c|}
83.99 \\
53 \\
\end{tabular} & 0 & 0 & 0 & 0 & \begin{tabular}{|c|}
0.75347 \\
2
\end{tabular} & 7.52728 & $\begin{array}{c}0.53288 \\
6\end{array}$ & 1 \\
\hline 40 & 1 & 2 & 1 & 2 & 1 & 1 & 1 & 1 & 0.73047 & $\begin{array}{c}0.66190 \\
7\end{array}$ & \begin{tabular}{c|}
- \\
39.9814 \\
\end{tabular} & $\begin{array}{c}- \\
39.9814\end{array}$ & $\begin{array}{c}0.79903 \\
3\end{array}$ & $\begin{array}{c}82.524 \\
2\end{array}$ & $\begin{array}{c}82.52 \\
42\end{array}$ & 0 & 0 & 0 & 0 & \begin{tabular}{|c|}
0.68931 \\
5
\end{tabular} & 3.4342 & \begin{tabular}{|c|}
0.09115 \\
1
\end{tabular} & \begin{tabular}{|c|}
0.8 \\
333 \\
33 \\
\end{tabular} \\
\hline 41 & 1 & 2 & 1 & 3 & 1 & 9 & 1 & 1 & \begin{tabular}{|c|}
0.73042 \\
2
\end{tabular} & $\begin{array}{c}0.64941 \\
2\end{array}$ & -37.453 & \begin{tabular}{|l|}
-37.453 \\
\end{tabular} & \begin{tabular}{|c|}
0.81143 \\
3
\end{tabular} & $\begin{array}{c}83.778 \\
6\end{array}$ & \begin{tabular}{|c|}
83.77 \\
86
\end{tabular} & 0 & 0 & 0 & 0 & \begin{tabular}{|c|}
0.70773 \\
1
\end{tabular} & 9.05332 & $\begin{array}{c}0.45514 \\
4\end{array}$ & \begin{tabular}{|c|}
0.8 \\
333 \\
33
\end{tabular} \\
\hline 42 & 1 & 2 & 1 & 3 & 1 & 14 & 1 & 1 & \begin{tabular}{|c|}
0.72990 \\
6
\end{tabular} & $\begin{array}{c}0.67339 \\
7\end{array}$ & \begin{tabular}{|c|}
- \\
37.9049 \\
\end{tabular} & $\begin{array}{c}- \\
37.9049 \\
\end{array}$ & \begin{tabular}{|c|}
0.78641 \\
4
\end{tabular} & $\begin{array}{c}81.203 \\
6\end{array}$ & \begin{tabular}{|c|}
81.20 \\
36
\end{tabular} & 0 & 0 & 0 & 0 & \begin{tabular}{|c|}
0.75676 \\
2
\end{tabular} & 8.95202 & $\begin{array}{c}0.32313 \\
6\end{array}$ & 1 \\
\hline 43 & 1 & 2 & 1 & 1 & 1 & 7 & 1 & 1 & \begin{tabular}{|c|}
0.72963 \\
4
\end{tabular} & $\begin{array}{c}0.66057 \\
9\end{array}$ & \begin{tabular}{|c|}
- \\
38.7287 \\
\end{tabular} & $\begin{array}{c}- \\
38.7287\end{array}$ & \begin{tabular}{|c|}
0.79868 \\
9
\end{tabular} & $\begin{array}{c}82.475 \\
9\end{array}$ & \begin{tabular}{|c|}
82.47 \\
59
\end{tabular} & 0 & 0 & 0 & 0 & \begin{tabular}{|c|}
0.68267 \\
3
\end{tabular} & 3.56574 & \begin{tabular}{|c|}
0.04791 \\
8
\end{tabular} & \begin{tabular}{|c|}
0.8 \\
333 \\
33
\end{tabular} \\
\hline 44 & 1 & 2 & 1 & 1 & 1 & 1 & 1 & 1 & 0.72943 & $\begin{array}{c}0.65662 \\
8\end{array}$ & $\begin{array}{c}- \\
40.1452\end{array}$ & $\begin{array}{c}- \\
40.1452\end{array}$ & \begin{tabular}{|c|}
0.80223 \\
2
\end{tabular} & $\begin{array}{c}82.853 \\
4\end{array}$ & \begin{tabular}{|c|}
82.85 \\
34
\end{tabular} & 0 & 0 & 0 & 0 & \begin{tabular}{|c|}
0.69062 \\
3
\end{tabular} & 3.45638 & \begin{tabular}{|c|}
0.08205 \\
2
\end{tabular} & \begin{tabular}{|c|}
0.8 \\
333 \\
33
\end{tabular} \\
\hline 45 & 1 & 2 & 1 & 3 & 1 & 8 & 1 & 1 & \begin{tabular}{|c|}
0.72839 \\
9
\end{tabular} & $\begin{array}{c}0.65001 \\
6\end{array}$ & \begin{tabular}{|c|}
- \\
37.8897
\end{tabular} & \begin{tabular}{|c|}
- \\
37.8897
\end{tabular} & \begin{tabular}{|c|}
0.80678 \\
1
\end{tabular} & $\begin{array}{c}83.288 \\
2\end{array}$ & \begin{tabular}{|c|}
83.28 \\
82
\end{tabular} & 0 & 0 & 0 & 0 & \begin{tabular}{|c|}
0.71169 \\
4
\end{tabular} & 4.23746 & $\begin{array}{c}0.41973 \\
6\end{array}$ & \begin{tabular}{|c|}
0.8 \\
333 \\
33 \\
\end{tabular} \\
\hline
\end{tabular}




\begin{tabular}{|c|c|c|c|c|c|c|c|c|c|c|c|c|c|c|c|c|c|c|c|c|c|c|c|}
\hline \begin{tabular}{|c|} 
Templ \\
ate
\end{tabular} & $\begin{array}{c}\text { Isomer } \\
\text { Substra } \\
\text { te 7:1 }\end{array}$ & \begin{tabular}{|c|} 
Conf \\
Substra \\
te $7: 1$
\end{tabular} & \begin{tabular}{|l|} 
Isomer \\
Substra \\
te 28:1
\end{tabular} & \begin{tabular}{|c|} 
Conf \\
Substra \\
te 28:1
\end{tabular} & \begin{tabular}{|c|} 
Isomer \\
Substrat \\
e 27:1
\end{tabular} & \begin{tabular}{|c|} 
Conf \\
Substra \\
te 27:1
\end{tabular} & \begin{tabular}{|l|} 
Isomer \\
Substra \\
te 13:1
\end{tabular} & \begin{tabular}{|c|} 
Conf \\
Substra \\
te 13:1
\end{tabular} & $\begin{array}{c}\text { Similarit } \\
y\end{array}$ & \begin{tabular}{|c} 
Field \\
Similarit \\
$y$
\end{tabular} & $\begin{array}{l}\text { Raw } \\
\text { Field } \\
\text { Score }\end{array}$ & \begin{tabular}{|c|} 
Penalis \\
ed Field \\
Score
\end{tabular} & \begin{tabular}{|c|} 
Shape \\
Similarit \\
$y$
\end{tabular} & \begin{tabular}{|c|} 
Raw \\
Shape \\
Score
\end{tabular} & \begin{tabular}{|c} 
Penali \\
sed \\
Shape \\
Score
\end{tabular} & \begin{tabular}{|c|} 
Tot \\
al \\
Pen \\
alty \\
\end{tabular} & \begin{tabular}{|c|} 
Exclud \\
ed \\
Volum \\
e \\
Clash \\
Penalt \\
y
\end{tabular} & \begin{tabular}{|c|} 
Atom \\
Distanc \\
e \\
Constrai \\
nt \\
Penalty
\end{tabular} & \begin{tabular}{|c|} 
Field \\
Value \\
Penalt \\
$y$
\end{tabular} & \begin{tabular}{|c|} 
Templat \\
e \\
Pairwis \\
e RMS \\
Similarit \\
y
\end{tabular} & \begin{tabular}{|c} 
Templat \\
e RMS \\
Angle \\
Deviatio \\
$n$
\end{tabular} & \begin{tabular}{|c} 
Templat \\
e RMS \\
Distanc \\
e \\
Deviatio \\
$n$
\end{tabular} & \begin{tabular}{|c|} 
Te \\
$\mathrm{mpl}$ \\
ate \\
Den \\
sity
\end{tabular} \\
\hline 46 & 1 & 1 & 1 & 3 & 1 & 6 & 1 & 1 & $\begin{array}{c}0.72757 \\
2\end{array}$ & 0.62936 & $\begin{array}{c}- \\
35.9123\end{array}$ & $\begin{array}{c}- \\
35.9123\end{array}$ & \begin{tabular}{|c}
0.82578 \\
3
\end{tabular} & $\begin{array}{c}85.276 \\
3\end{array}$ & $\begin{array}{c}85.27 \\
63\end{array}$ & 0 & 0 & 0 & 0 & $\begin{array}{c}0.63990 \\
7\end{array}$ & 4.77606 & $\begin{array}{c}0.24752 \\
2\end{array}$ & $\begin{array}{c}0.6 \\
666 \\
67\end{array}$ \\
\hline 47 & 1 & 2 & 1 & 2 & 1 & 2 & 1 & 1 & $\begin{array}{c}0.72702 \\
7\end{array}$ & $\begin{array}{c}0.71570 \\
7\end{array}$ & -38.607 & \begin{tabular}{|l|}
-38.607 \\
\end{tabular} & $\begin{array}{c}0.73834 \\
8\end{array}$ & $\begin{array}{c}76.317 \\
3\end{array}$ & \begin{tabular}{|c|}
76.31 \\
73
\end{tabular} & 0 & 0 & 0 & 0 & $\begin{array}{c}0.68679 \\
5\end{array}$ & 8.34881 & $\begin{array}{c}0.25329 \\
4\end{array}$ & $\begin{array}{c}0.8 \\
333 \\
33 \\
\end{array}$ \\
\hline 48 & 1 & 1 & 1 & 3 & 1 & 4 & 1 & 1 & $\begin{array}{c}0.72671 \\
7\end{array}$ & $\begin{array}{c}0.69454 \\
3\end{array}$ & 39.5651 & 39.5651 & 0.75889 & $\begin{array}{c}78.431 \\
2\end{array}$ & \begin{tabular}{|c|}
78.43 \\
12
\end{tabular} & 0 & 0 & 0 & 0 & $\begin{array}{c}0.68516 \\
8\end{array}$ & 8.99329 & $\begin{array}{c}0.22721 \\
1\end{array}$ & \begin{tabular}{|c|}
0.8 \\
333 \\
33
\end{tabular} \\
\hline 49 & 1 & 2 & 1 & 3 & 1 & 1 & 1 & 1 & $\begin{array}{c}0.72668 \\
3 \\
\end{array}$ & \begin{tabular}{|c}
0.65858 \\
3 \\
\end{tabular} & -38.751 & -38.751 & \begin{tabular}{|c}
0.79478 \\
4
\end{tabular} & $\begin{array}{c}82.080 \\
2 \\
\end{array}$ & \begin{tabular}{|c|}
82.08 \\
02
\end{tabular} & 0 & 0 & 0 & 0 & $\begin{array}{c}0.76381 \\
1 \\
\end{array}$ & 4.12981 & \begin{tabular}{|c}
0.47736 \\
3 \\
\end{tabular} & 1 \\
\hline 50 & 1 & 1 & 1 & 3 & 1 & 14 & 1 & 1 & $\begin{array}{c}0.72530 \\
3 \\
\end{array}$ & \begin{tabular}{|c}
0.65798 \\
3 \\
\end{tabular} & $\begin{array}{c}- \\
37.2999 \\
\end{array}$ & $\begin{array}{c}- \\
37.2999 \\
\end{array}$ & \begin{tabular}{|c}
0.79262 \\
2 \\
\end{tabular} & $\begin{array}{c}81.870 \\
6 \\
\end{array}$ & \begin{tabular}{|c|}
81.87 \\
06
\end{tabular} & 0 & 0 & 0 & 0 & \begin{tabular}{|c}
0.74565 \\
7 \\
\end{tabular} & $\mid 6.80884$ & \begin{tabular}{|c}
0.40488 \\
9 \\
\end{tabular} & 1 \\
\hline 51 & 1 & 2 & 1 & 1 & 1 & 3 & 1 & 1 & $\begin{array}{c}0.72525 \\
5\end{array}$ & $\begin{array}{c}0.70979 \\
8\end{array}$ & $\begin{array}{c}- \\
38.7825\end{array}$ & $\begin{array}{c}- \\
38.7825\end{array}$ & $\begin{array}{c}0.74071 \\
1\end{array}$ & $\begin{array}{c}76.557 \\
4\end{array}$ & $\begin{array}{c}76.55 \\
74\end{array}$ & 0 & 0 & 0 & 0 & \begin{tabular}{|c}
0.68416 \\
3
\end{tabular} & 8.41145 & $\begin{array}{c}0.23602 \\
4\end{array}$ & \begin{tabular}{|c|}
0.8 \\
333 \\
33
\end{tabular} \\
\hline 52 & 1 & 2 & 1 & 1 & 1 & 14 & 1 & 1 & $\begin{array}{c}0.72441 \\
9\end{array}$ & $\begin{array}{c}0.68210 \\
3\end{array}$ & $\begin{array}{c}- \\
39.8898\end{array}$ & $\begin{array}{c}- \\
39.8898 \\
\end{array}$ & $\begin{array}{c}0.76673 \\
6\end{array}$ & $\begin{array}{c}79.210 \\
1\end{array}$ & \begin{tabular}{|c|}
79.21 \\
01
\end{tabular} & 0 & 0 & 0 & 0 & \begin{tabular}{|c}
0.68337 \\
3
\end{tabular} & 7.54781 & $\begin{array}{c}0.14904 \\
5\end{array}$ & $\begin{array}{c}0.8 \\
333 \\
33 \\
\end{array}$ \\
\hline 53 & 1 & 1 & 1 & 3 & 1 & 8 & 1 & 1 & $\begin{array}{c}0.72228 \\
4\end{array}$ & 0.64315 & $\begin{array}{c}- \\
37.3771\end{array}$ & $\begin{array}{c}- \\
37.3771\end{array}$ & $\begin{array}{c}0.80141 \\
9\end{array}$ & $\begin{array}{c}82.786 \\
3\end{array}$ & $\begin{array}{c}82.78 \\
63\end{array}$ & 0 & 0 & 0 & 0 & $\begin{array}{c}0.68728 \\
3\end{array}$ & 4.03096 & $\begin{array}{c}0.15714 \\
7\end{array}$ & \begin{tabular}{|c|}
0.8 \\
333 \\
33
\end{tabular} \\
\hline 54 & 1 & 2 & 1 & 1 & 1 & 4 & 1 & 1 & 0.72216 & $\begin{array}{c}0.70234 \\
8\end{array}$ & $\begin{array}{c}- \\
41.2095\end{array}$ & $\begin{array}{c}- \\
41.2095\end{array}$ & $\begin{array}{c}0.74197 \\
1\end{array}$ & $\begin{array}{c}76.692 \\
7\end{array}$ & $\begin{array}{c}76.69 \\
27\end{array}$ & 0 & 0 & 0 & 0 & $\begin{array}{c}0.68117 \\
2\end{array}$ & 7.46824 & $\begin{array}{c}0.13410 \\
1\end{array}$ & \begin{tabular}{|c|}
0.8 \\
333 \\
33 \\
\end{tabular} \\
\hline 55 & 1 & 2 & 1 & 1 & 1 & 10 & 1 & 1 & $\begin{array}{c}0.72031 \\
5\end{array}$ & $\begin{array}{c}0.65262 \\
7\end{array}$ & $\begin{array}{c}- \\
38.4087\end{array}$ & $\begin{array}{c}- \\
38.4087\end{array}$ & $\begin{array}{c}0.78800 \\
3\end{array}$ & $\begin{array}{c}81.369 \\
2\end{array}$ & \begin{tabular}{|c|}
81.36 \\
92
\end{tabular} & 0 & 0 & 0 & 0 & \begin{tabular}{|c|}
0.63738 \\
2
\end{tabular} & 9.16799 & $\begin{array}{c}0.23501 \\
3\end{array}$ & \begin{tabular}{|c|}
0.6 \\
666 \\
67 \\
\end{tabular} \\
\hline 56 & 1 & 2 & 1 & 1 & 1 & 13 & 1 & 1 & $\begin{array}{c}0.71962 \\
8\end{array}$ & $\begin{array}{c}0.64641 \\
8\end{array}$ & $\begin{array}{c}- \\
38.3293\end{array}$ & $\begin{array}{c}- \\
38.3293\end{array}$ & $\begin{array}{c}0.79283 \\
7\end{array}$ & $\begin{array}{c}81.875 \\
8\end{array}$ & \begin{tabular}{|c|}
81.87 \\
58
\end{tabular} & 0 & 0 & 0 & 0 & 0.63771 & 9.94777 & $\begin{array}{c}0.27347 \\
7\end{array}$ & $\begin{array}{c}0.6 \\
666 \\
67\end{array}$ \\
\hline 57 & 1 & 2 & 1 & 2 & 1 & 14 & 1 & 1 & $\begin{array}{c}0.71887 \\
8\end{array}$ & 0.67708 & $\begin{array}{c}- \\
39.0814\end{array}$ & $\begin{array}{c}- \\
39.0814\end{array}$ & $\begin{array}{c}0.76067 \\
7\end{array}$ & $\begin{array}{c}78.578 \\
6\end{array}$ & $\begin{array}{c}78.57 \\
86\end{array}$ & 0 & 0 & 0 & 0 & $\begin{array}{c}0.68205 \\
1\end{array}$ & 8.0946 & 0.16225 & $\begin{array}{c}0.8 \\
333 \\
33 \\
\end{array}$ \\
\hline 58 & 1 & 2 & 1 & 3 & 1 & 8 & 1 & 1 & $\begin{array}{c}0.71696 \\
2\end{array}$ & \begin{tabular}{|c}
0.65844 \\
1
\end{tabular} & $\begin{array}{c}- \\
38.4283\end{array}$ & $\begin{array}{c}- \\
38.4283 \\
\end{array}$ & \begin{tabular}{|c}
0.77548 \\
3
\end{tabular} & $\begin{array}{c}80.091 \\
2\end{array}$ & $\begin{array}{c}80.09 \\
12\end{array}$ & 0 & 0 & 0 & 0 & \begin{tabular}{|c|}
0.68218 \\
8
\end{tabular} & 8.11201 & $\begin{array}{c}0.51645 \\
9\end{array}$ & $\begin{array}{c}0.8 \\
333 \\
33 \\
\end{array}$ \\
\hline
\end{tabular}




\begin{tabular}{|c|c|c|c|c|c|c|c|c|c|c|c|c|c|c|c|c|c|c|c|c|c|c|c|}
\hline \begin{tabular}{|c|}
$\begin{array}{c}\text { Templ } \\
\text { ate }\end{array}$ \\
\end{tabular} & $\begin{array}{c}\text { Isomer } \\
\text { Substra } \\
\text { te 7:1 }\end{array}$ & $\begin{array}{c}\text { Conf } \\
\text { Substra } \\
\text { te } 7: 1\end{array}$ & $\begin{array}{l}\text { Isomer } \\
\text { Substra } \\
\text { te 28:1 }\end{array}$ & $\begin{array}{l}\text { Conf } \\
\text { Substra } \\
\text { te 28:1 }\end{array}$ & \begin{tabular}{|c|} 
Isomer \\
Substrat \\
e 27:1
\end{tabular} & \begin{tabular}{c|} 
Conf \\
Substra \\
te 27:1
\end{tabular} & \begin{tabular}{|l|} 
Isomer \\
Substra \\
te 13:1
\end{tabular} & \begin{tabular}{|c|} 
Conf \\
Substra \\
te 13:1
\end{tabular} & \begin{tabular}{|c|} 
Similarit \\
$y$
\end{tabular} & \begin{tabular}{|c|} 
Field \\
Similarit \\
$y$
\end{tabular} & $\begin{array}{l}\text { Raw } \\
\text { Field } \\
\text { Score }\end{array}$ & \begin{tabular}{|c|} 
Penalis \\
ed Field \\
Score
\end{tabular} & \begin{tabular}{|c|} 
Shape \\
Similarit \\
$y$
\end{tabular} & \begin{tabular}{|c|} 
Raw \\
Shape \\
Score \\
\end{tabular} & \begin{tabular}{|c|} 
Penali \\
sed \\
Shape \\
Score
\end{tabular} & \begin{tabular}{|c|} 
Tot \\
al \\
Pen \\
alty \\
\\
\end{tabular} & \begin{tabular}{|c|} 
Exclud \\
ed \\
Volum \\
e \\
Clash \\
Penalt \\
$y$ \\
\end{tabular} & \begin{tabular}{|c|} 
Atom \\
Distanc \\
e \\
Constrai \\
nt \\
Penalty \\
\end{tabular} & \begin{tabular}{|c|} 
Field \\
Value \\
Penalt \\
$y$
\end{tabular} & \begin{tabular}{|c|} 
Templat \\
e \\
Pairwis \\
e RMS \\
Similarit \\
y \\
\end{tabular} & \begin{tabular}{|c|} 
Templat \\
e RMS \\
Angle \\
Deviatio \\
$n$
\end{tabular} & \begin{tabular}{|c|} 
Templat \\
e RMS \\
Distanc \\
e \\
Deviatio \\
n
\end{tabular} & \begin{tabular}{|l|} 
Te \\
mpl \\
ate \\
Den \\
sity
\end{tabular} \\
\hline 59 & 1 & 2 & 1 & 3 & 1 & 14 & 1 & 1 & \begin{tabular}{|c|}
0.71324 \\
8
\end{tabular} & \begin{tabular}{|c|}
0.65694 \\
7
\end{tabular} & $\begin{array}{c}- \\
37.0565 \\
\end{array}$ & \begin{tabular}{c|}
- \\
37.0565 \\
\end{tabular} & 0.76955 & $\begin{array}{c}79.481 \\
1\end{array}$ & \begin{tabular}{|c|}
79.48 \\
11
\end{tabular} & 0 & 0 & 0 & 0 & \begin{tabular}{|c|}
0.67843 \\
4
\end{tabular} & 7.97792 & $\begin{array}{c}0.27048 \\
6\end{array}$ & \begin{tabular}{|c|}
0.8 \\
333 \\
33
\end{tabular} \\
\hline 60 & 1 & 1 & 1 & 3 & 1 & 8 & 1 & 1 & \begin{tabular}{|c|}
0.70896 \\
5
\end{tabular} & \begin{tabular}{|c|}
0.61536 \\
7
\end{tabular} & $\begin{array}{c}- \\
36.1443 \\
\end{array}$ & $\begin{array}{c}- \\
36.1443\end{array}$ & $\begin{array}{c}0.80256 \\
3\end{array}$ & 82.891 & $\begin{array}{c}82.89 \\
1\end{array}$ & 0 & 0 & 0 & 0 & \begin{tabular}{|c|}
0.70389 \\
8
\end{tabular} & 4.34522 & $\begin{array}{c}0.58733 \\
5\end{array}$ & \begin{tabular}{|c|}
0.8 \\
333 \\
33 \\
\end{tabular} \\
\hline 61 & 1 & 2 & 1 & 3 & 1 & 1 & 1 & 1 & \begin{tabular}{|c|}
0.70894 \\
7
\end{tabular} & \begin{tabular}{|c|}
0.62973 \\
3
\end{tabular} & $\begin{array}{c}- \\
37.3424 \\
\end{array}$ & $\begin{array}{c}- \\
37.3424 \\
\end{array}$ & 0.78816 & $\begin{array}{c}81.408 \\
7\end{array}$ & \begin{tabular}{|l|}
81.40 \\
87
\end{tabular} & 0 & 0 & 0 & 0 & $\begin{array}{c}0.68098 \\
3\end{array}$ & 3.45218 & $\begin{array}{c}0.43576 \\
8\end{array}$ & \begin{tabular}{|c|}
0.8 \\
333 \\
33 \\
\end{tabular} \\
\hline 62 & 1 & 1 & 1 & 3 & 1 & 9 & 1 & 1 & 0.70046 & 0.60183 & $\begin{array}{c}- \\
35.0049 \\
\end{array}$ & \begin{tabular}{c|}
- \\
35.0049
\end{tabular} & $\begin{array}{c}0.79908 \\
9\end{array}$ & $\begin{array}{c}82.533 \\
4\end{array}$ & \begin{tabular}{|c|}
82.53 \\
34
\end{tabular} & 0 & 0 & 0 & 0 & $\begin{array}{c}0.69616 \\
3\end{array}$ & 3.78372 & $\begin{array}{c}0.55973 \\
6\end{array}$ & \begin{tabular}{|c|}
0.8 \\
333 \\
33 \\
\end{tabular} \\
\hline 63 & 1 & 1 & 1 & 3 & 1 & 1 & 1 & 1 & \begin{tabular}{|c|}
0.69991 \\
9
\end{tabular} & \begin{tabular}{|c|}
0.62413 \\
9
\end{tabular} & \begin{tabular}{c|}
- \\
37.2087 \\
\end{tabular} & \begin{tabular}{|c|}
- \\
37.2087 \\
\end{tabular} & 0.7757 & $\begin{array}{c}80.126 \\
5\end{array}$ & $\begin{array}{c}80.12 \\
65\end{array}$ & 0 & 0 & 0 & 0 & \begin{tabular}{|c|}
0.68226 \\
1
\end{tabular} & 8.84066 & \begin{tabular}{|c|}
0.59707 \\
7
\end{tabular} & \begin{tabular}{|c|}
0.8 \\
333 \\
33 \\
\end{tabular} \\
\hline 64 & 1 & 1 & 1 & 3 & 1 & 7 & 1 & 1 & \begin{tabular}{|c|}
0.69866 \\
3
\end{tabular} & \begin{tabular}{|c|}
0.60653 \\
8
\end{tabular} & $\begin{array}{c}- \\
34.2882 \\
\end{array}$ & \begin{tabular}{|c|}
- \\
34.2882 \\
\end{tabular} & $\begin{array}{c}0.79078 \\
8\end{array}$ & $\begin{array}{c}81.693 \\
5\end{array}$ & \begin{tabular}{|c|}
81.69 \\
35
\end{tabular} & 0 & 0 & 0 & 0 & $\begin{array}{c}0.67149 \\
6\end{array}$ & 9.94607 & $\begin{array}{c}0.51512 \\
6\end{array}$ & \begin{tabular}{|c|}
0.8 \\
333 \\
33 \\
\end{tabular} \\
\hline 65 & 1 & 1 & 1 & 3 & 1 & 14 & 1 & 1 & \begin{tabular}{|c|}
0.68849 \\
6
\end{tabular} & \begin{tabular}{|c|}
0.61285 \\
1
\end{tabular} & $\begin{array}{c}- \\
34.8175 \\
\end{array}$ & \begin{tabular}{|c|}
- \\
34.8175
\end{tabular} & $\begin{array}{c}0.76414 \\
1\end{array}$ & $\begin{array}{c}78.926 \\
7\end{array}$ & \begin{tabular}{|c|}
78.92 \\
67
\end{tabular} & 0 & 0 & 0 & 0 & \begin{tabular}{|c|}
0.67167 \\
7
\end{tabular} & 9.23378 & \begin{tabular}{|c|}
0.48649 \\
2
\end{tabular} & \begin{tabular}{|c|}
0.8 \\
333 \\
33
\end{tabular} \\
\hline 66 & 1 & 1 & 1 & 3 & 1 & 1 & 1 & 1 & \begin{tabular}{|c|}
0.67987 \\
7
\end{tabular} & \begin{tabular}{|c|}
0.58410 \\
1
\end{tabular} & $\begin{array}{c}- \\
34.8305\end{array}$ & \begin{tabular}{c|}
- \\
34.8305
\end{tabular} & $\begin{array}{c}0.77565 \\
3\end{array}$ & $\begin{array}{c}80.131 \\
1\end{array}$ & $\begin{array}{c}80.13 \\
11\end{array}$ & 0 & 0 & 0 & 0 & $\begin{array}{c}0.67158 \\
3\end{array}$ & 2.76069 & $\begin{array}{c}0.59471 \\
4\end{array}$ & \begin{tabular}{|c|}
0.8 \\
333 \\
33 \\
\end{tabular} \\
\hline 67 & 1 & 2 & 1 & 3 & 1 & 2 & & & \begin{tabular}{|c|}
0.81111 \\
3 \\
\end{tabular} & \begin{tabular}{|c|}
0.83606 \\
2 \\
\end{tabular} & \begin{tabular}{c|}
- \\
43.5187 \\
\end{tabular} & \begin{tabular}{|c|}
- \\
43.5187 \\
\end{tabular} & \begin{tabular}{|c|}
0.78616 \\
3 \\
\end{tabular} & $\begin{array}{c}82.145 \\
3 \\
\end{array}$ & \begin{tabular}{|c|}
82.14 \\
53 \\
\end{tabular} & 0 & 0 & 0 & 0 & \begin{tabular}{|c|}
0.81412 \\
2 \\
\end{tabular} & 2.33513 & \begin{tabular}{|c|}
0.07900 \\
2 \\
\end{tabular} & 1 \\
\hline 68 & 1 & 2 & 1 & 3 & 1 & 5 & & & \begin{tabular}{|c|}
0.81049 \\
3 \\
\end{tabular} & \begin{tabular}{|c|}
0.82886 \\
3 \\
\end{tabular} & \begin{tabular}{|c|}
- \\
47.1211 \\
\end{tabular} & \begin{tabular}{|c|}
- \\
47.1211 \\
\end{tabular} & \begin{tabular}{|c|}
0.79212 \\
2 \\
\end{tabular} & \begin{tabular}{|c|}
82.768 \\
5 \\
\end{tabular} & \begin{tabular}{|c|}
82.76 \\
85 \\
\end{tabular} & 0 & 0 & 0 & 0 & \begin{tabular}{|c|}
0.81256 \\
7 \\
\end{tabular} & 3.32677 & \begin{tabular}{|c|}
0.10660 \\
7 \\
\end{tabular} & 1 \\
\hline 69 & 1 & 2 & 1 & 3 & 1 & 4 & & & \begin{tabular}{|c|}
0.80945 \\
3
\end{tabular} & \begin{tabular}{|c|}
0.82625 \\
9
\end{tabular} & $\begin{array}{c}- \\
47.2329 \\
\end{array}$ & \begin{tabular}{|c|}
- \\
47.2329 \\
\end{tabular} & $\begin{array}{c}0.79264 \\
8\end{array}$ & $\begin{array}{c}82.829 \\
5\end{array}$ & \begin{tabular}{|c|}
82.82 \\
95 \\
\end{tabular} & 0 & 0 & 0 & 0 & \begin{tabular}{|c|}
0.81320 \\
9
\end{tabular} & 2.93106 & \begin{tabular}{|c|}
0.07875 \\
6 \\
\end{tabular} & 1 \\
\hline 70 & 1 & 2 & 1 & 3 & 1 & 3 & & & \begin{tabular}{|c|}
0.80704 \\
7 \\
\end{tabular} & \begin{tabular}{|c|}
0.82828 \\
7 \\
\end{tabular} & $\begin{array}{c}- \\
43.0644 \\
\end{array}$ & \begin{tabular}{|c|}
- \\
43.0644 \\
\end{tabular} & \begin{tabular}{|c|}
0.78580 \\
8 \\
\end{tabular} & $\begin{array}{c}82.114 \\
6 \\
\end{array}$ & \begin{tabular}{|c|}
82.11 \\
46 \\
\end{tabular} & 0 & 0 & 0 & 0 & \begin{tabular}{|c|}
0.81068 \\
7 \\
\end{tabular} & 3.63525 & \begin{tabular}{|c|}
0.07944 \\
5 \\
\end{tabular} & 1 \\
\hline 71 & 1 & 2 & 1 & 2 & 1 & 4 & & & 0.80003 & \begin{tabular}{|c|}
0.81580 \\
1 \\
\end{tabular} & \begin{tabular}{|c|}
- \\
48.2449 \\
\end{tabular} & \begin{tabular}{|c|}
- \\
48.2449 \\
\end{tabular} & $\begin{array}{c}0.78425 \\
9 \\
\end{array}$ & \begin{tabular}{|c|}
81.981 \\
5 \\
\end{tabular} & \begin{tabular}{|c|}
81.98 \\
15 \\
\end{tabular} & 0 & 0 & 0 & 0 & \begin{tabular}{|c|}
0.79713 \\
2 \\
\end{tabular} & 2.97648 & \begin{tabular}{|c|}
0.07991 \\
2 \\
\end{tabular} & 1 \\
\hline 72 & 1 & 2 & 1 & 1 & 1 & 5 & & & \begin{tabular}{|c|}
0.79961 \\
7 \\
\end{tabular} & \begin{tabular}{|c|}
0.82062 \\
1 \\
\end{tabular} & \begin{tabular}{|c|}
- \\
49.0783 \\
\end{tabular} & \begin{tabular}{|c|}
- \\
49.0783 \\
\end{tabular} & \begin{tabular}{|c|}
0.77861 \\
3
\end{tabular} & 81.387 & \begin{tabular}{|c|}
81.38 \\
7
\end{tabular} & 0 & 0 & 0 & 0 & \begin{tabular}{|c|}
0.79971 \\
6 \\
\end{tabular} & 4.23137 & \begin{tabular}{|c|}
0.16901 \\
3
\end{tabular} & 1 \\
\hline 73 & 1 & 2 & 1 & 1 & 1 & 2 & & & 0.79729 & \begin{tabular}{|c|}
0.81415 \\
1
\end{tabular} & \begin{tabular}{|c|}
- \\
44.5889 \\
\end{tabular} & \begin{tabular}{|c|}
- \\
44.5889 \\
\end{tabular} & \begin{tabular}{|c|}
0.78042 \\
9
\end{tabular} & \begin{tabular}{|c|}
81.567 \\
8
\end{tabular} & $\begin{array}{c}81.56 \\
78 \\
\end{array}$ & 0 & 0 & 0 & 0 & \begin{tabular}{|c|}
0.79978 \\
5 \\
\end{tabular} & 2.74327 & \begin{tabular}{|c|}
0.10954 \\
9
\end{tabular} & 1 \\
\hline
\end{tabular}




\begin{tabular}{|c|c|c|c|c|c|c|c|c|c|c|c|c|c|c|c|c|c|c|c|c|c|c|c|}
\hline $\begin{array}{c}\text { Templ } \\
\text { ate }\end{array}$ & $\begin{array}{c}\text { Isomer } \\
\text { Substra } \\
\text { te } 7: 1\end{array}$ & $\begin{array}{c}\text { Conf } \\
\text { Substra } \\
\text { te } 7: 1\end{array}$ & $\begin{array}{l}\text { Isomer } \\
\text { Substra } \\
\text { te 28:1 }\end{array}$ & \begin{tabular}{|c|} 
Conf \\
Substra \\
te $28: 1$
\end{tabular} & \begin{tabular}{|c|} 
Isomer \\
Substrat \\
e 27:1
\end{tabular} & \begin{tabular}{|c|} 
Conf \\
Substra \\
te $27: 1$
\end{tabular} & \begin{tabular}{|l|} 
Isomer \\
Substra \\
te 13:1
\end{tabular} & \begin{tabular}{|c|} 
Conf \\
Substra \\
te 13:1
\end{tabular} & \begin{tabular}{|c|} 
Similarit \\
$y$
\end{tabular} & \begin{tabular}{|c|} 
Field \\
Similarit \\
$y$
\end{tabular} & $\begin{array}{l}\text { Raw } \\
\text { Field } \\
\text { Score }\end{array}$ & \begin{tabular}{|c|} 
Penalis \\
ed Field \\
Score
\end{tabular} & \begin{tabular}{|c|} 
Shape \\
Similarit \\
$y$
\end{tabular} & \begin{tabular}{|c|} 
Raw \\
Shape \\
Score \\
\end{tabular} & \begin{tabular}{|c} 
Penali \\
sed \\
Shape \\
Score
\end{tabular} & \begin{tabular}{|c|} 
Tot \\
al \\
Pen \\
alty
\end{tabular} & \begin{tabular}{|c|} 
Exclud \\
ed \\
Volum \\
e \\
Clash \\
Penalt \\
y \\
\end{tabular} & \begin{tabular}{|c|} 
Atom \\
Distanc \\
e \\
Constrai \\
nt \\
Penalty \\
\end{tabular} & \begin{tabular}{|c|} 
Field \\
Value \\
Penalt \\
$y$
\end{tabular} & \begin{tabular}{|c} 
Templat \\
e \\
Pairwis \\
e RMS \\
Similarit \\
$y$
\end{tabular} & $\begin{array}{c}\text { Templat } \\
\text { e RMS } \\
\text { Angle } \\
\text { Deviatio } \\
n\end{array}$ & \begin{tabular}{|c|} 
Templat \\
e RMS \\
Distanc \\
e \\
Deviatio \\
n \\
\end{tabular} & \begin{tabular}{|c|} 
Te \\
mpl \\
ate \\
Den \\
sity
\end{tabular} \\
\hline 74 & 1 & 2 & 1 & 2 & 1 & 3 & & & \begin{tabular}{|c|}
0.79520 \\
2 \\
\end{tabular} & \begin{tabular}{|c|}
0.81053 \\
5 \\
\end{tabular} & -43.555 & -43.555 & \begin{tabular}{|c|}
0.77986 \\
9
\end{tabular} & \begin{tabular}{|c|}
81.512 \\
8
\end{tabular} & \begin{tabular}{|c|}
81.51 \\
28
\end{tabular} & 0 & 0 & 0 & 0 & $\begin{array}{c}0.79381 \\
7\end{array}$ & 1.93182 & 0.04804 & 1 \\
\hline 75 & 1 & 2 & 1 & 3 & 1 & 8 & & & \begin{tabular}{|c|}
0.79018 \\
5 \\
\end{tabular} & \begin{tabular}{|c|}
0.76655 \\
6 \\
\end{tabular} & $\begin{array}{c}- \\
45.4255 \\
\end{array}$ & $\begin{array}{c}- \\
45.4255 \\
\end{array}$ & \begin{tabular}{|c|}
0.81381 \\
3
\end{tabular} & $\begin{array}{c}85.008 \\
3\end{array}$ & $\begin{array}{c}85.00 \\
83\end{array}$ & 0 & 0 & 0 & 0 & $\begin{array}{c}0.81884 \\
9\end{array}$ & 2.80693 & 0.46356 & 1 \\
\hline 76 & 1 & 2 & 1 & 2 & 1 & 2 & & & \begin{tabular}{|c|}
0.78620 \\
5 \\
\end{tabular} & \begin{tabular}{|c|}
0.78835 \\
6 \\
\end{tabular} & $\begin{array}{c}- \\
42.3482 \\
\end{array}$ & $\begin{array}{c}- \\
42.3482 \\
\end{array}$ & \begin{tabular}{|c|}
0.78405 \\
3 \\
\end{tabular} & \begin{tabular}{|c|}
81.939 \\
2 \\
\end{tabular} & \begin{tabular}{|c|}
81.93 \\
92
\end{tabular} & 0 & 0 & 0 & 0 & $\begin{array}{c}0.79114 \\
7 \\
\end{array}$ & 7.79474 & \begin{tabular}{|c|}
0.21038 \\
1 \\
\end{tabular} & 1 \\
\hline 77 & 1 & 2 & 1 & 3 & 1 & 9 & & & \begin{tabular}{|c|}
0.78384 \\
1 \\
\end{tabular} & \begin{tabular}{|c|}
0.75484 \\
5 \\
\end{tabular} & $\begin{array}{c}- \\
44.1232 \\
\end{array}$ & $\begin{array}{c}- \\
44.1232 \\
\end{array}$ & \begin{tabular}{|c|}
0.81283 \\
8 \\
\end{tabular} & \begin{tabular}{|c|}
84.904 \\
5 \\
\end{tabular} & \begin{tabular}{|c|}
84.90 \\
45
\end{tabular} & 0 & 0 & 0 & 0 & \begin{tabular}{|c|}
0.81525 \\
2
\end{tabular} & 9.78308 & \begin{tabular}{|c|}
0.51552 \\
5 \\
\end{tabular} & 1 \\
\hline 78 & 1 & 2 & 1 & 1 & 1 & 3 & & & \begin{tabular}{|c|}
0.78311 \\
1 \\
\end{tabular} & \begin{tabular}{|c|}
0.78308 \\
6
\end{tabular} & -42.818 & -42.818 & \begin{tabular}{|c|}
0.78313 \\
6
\end{tabular} & \begin{tabular}{|c|}
81.822 \\
2 \\
\end{tabular} & \begin{tabular}{|c|}
81.82 \\
22 \\
\end{tabular} & 0 & 0 & 0 & 0 & \begin{tabular}{|c|}
0.78914 \\
4
\end{tabular} & 7.86352 & \begin{tabular}{|c|}
0.20162 \\
4
\end{tabular} & 1 \\
\hline 79 & 1 & 1 & 1 & 3 & 1 & 3 & & & \begin{tabular}{|c|}
0.77930 \\
6 \\
\end{tabular} & \begin{tabular}{|c|}
0.76720 \\
1 \\
\end{tabular} & $\begin{array}{c}- \\
40.2044 \\
\end{array}$ & $\begin{array}{c}- \\
40.2044 \\
\end{array}$ & \begin{tabular}{|c|}
0.79141 \\
2 \\
\end{tabular} & 82.695 & \begin{tabular}{|c|}
82.69 \\
5 \\
\end{tabular} & 0 & 0 & 0 & 0 & \begin{tabular}{|c|}
0.78609 \\
5 \\
\end{tabular} & 1.093 & \begin{tabular}{|c|}
0.18761 \\
3 \\
\end{tabular} & 1 \\
\hline 80 & 1 & 2 & 1 & 1 & 1 & 4 & & & \begin{tabular}{|c|}
0.77836 \\
8 \\
\end{tabular} & \begin{tabular}{|c|}
0.77029 \\
3 \\
\end{tabular} & \begin{tabular}{|l|}
-46.098 \\
\end{tabular} & -46.098 & \begin{tabular}{|c|}
0.78644 \\
4 \\
\end{tabular} & \begin{tabular}{|c|}
82.199 \\
8 \\
\end{tabular} & \begin{tabular}{|c|}
82.19 \\
98 \\
\end{tabular} & 0 & 0 & 0 & 0 & 0.78604 & 8.15452 & \begin{tabular}{|c|}
0.15351 \\
2 \\
\end{tabular} & 1 \\
\hline 81 & 1 & 1 & 1 & 3 & 1 & 4 & & & \begin{tabular}{|c|}
0.77796 \\
9 \\
\end{tabular} & \begin{tabular}{|c|}
0.75781 \\
1 \\
\end{tabular} & $\begin{array}{c}- \\
43.7144 \\
\end{array}$ & $\begin{array}{c}- \\
43.7144 \\
\end{array}$ & \begin{tabular}{|c|}
0.79812 \\
7
\end{tabular} & 83.401 & $\begin{array}{c}83.40 \\
1\end{array}$ & 0 & 0 & 0 & 0 & 0.78045 & 3.02921 & \begin{tabular}{|c|}
0.22055 \\
1 \\
\end{tabular} & 1 \\
\hline 82 & 1 & 1 & 1 & 3 & 1 & 5 & & & \begin{tabular}{|c|}
0.77765 \\
6 \\
\end{tabular} & \begin{tabular}{|c|}
0.76225 \\
5 \\
\end{tabular} & \begin{tabular}{c|}
- \\
43.7193 \\
\end{tabular} & $\begin{array}{c}- \\
43.7193 \\
\end{array}$ & \begin{tabular}{|c|}
0.79305 \\
6 \\
\end{tabular} & \begin{tabular}{|c|}
82.869 \\
5 \\
\end{tabular} & \begin{tabular}{|c|}
82.86 \\
95 \\
\end{tabular} & 0 & 0 & 0 & 0 & \begin{tabular}{|c|}
0.78201 \\
7
\end{tabular} & 1.37306 & \begin{tabular}{|c|}
0.11338 \\
1 \\
\end{tabular} & 1 \\
\hline 83 & 1 & 2 & 1 & 2 & 1 & 5 & & & \begin{tabular}{|c|}
0.77711 \\
2 \\
\end{tabular} & \begin{tabular}{|c|}
0.77197 \\
8 \\
\end{tabular} & \begin{tabular}{|c|}
- \\
45.2453 \\
\end{tabular} & $\begin{array}{c}- \\
45.2453 \\
\end{array}$ & \begin{tabular}{|c|}
0.78224 \\
5 \\
\end{tabular} & \begin{tabular}{|c|}
81.762 \\
3 \\
\end{tabular} & $\begin{array}{c}81.76 \\
23 \\
\end{array}$ & 0 & 0 & 0 & 0 & \begin{tabular}{|c|}
0.78194 \\
8
\end{tabular} & 5.50333 & \begin{tabular}{|c|}
0.10019 \\
6
\end{tabular} & 1 \\
\hline 84 & 1 & 1 & 1 & 3 & 1 & 2 & & & \begin{tabular}{|c|}
0.77675 \\
1 \\
\end{tabular} & \begin{tabular}{|c|}
0.76188 \\
4 \\
\end{tabular} & \begin{tabular}{c|}
- \\
40.0177 \\
\end{tabular} & $\begin{array}{c}- \\
40.0177 \\
\end{array}$ & \begin{tabular}{|c|}
0.79161 \\
9 \\
\end{tabular} & \begin{tabular}{|c|}
82.719 \\
1 \\
\end{tabular} & \begin{tabular}{|c|}
82.71 \\
91
\end{tabular} & 0 & 0 & 0 & 0 & \begin{tabular}{|c|}
0.77632 \\
9
\end{tabular} & 3.73515 & \begin{tabular}{|c|}
0.19523 \\
8 \\
\end{tabular} & 1 \\
\hline 85 & 1 & 2 & 1 & 2 & 1 & 7 & & & 0.76214 & \begin{tabular}{|c|}
0.69802 \\
7 \\
\end{tabular} & $\begin{array}{c}- \\
41.2516 \\
\end{array}$ & $\begin{array}{c}- \\
41.2516 \\
\end{array}$ & \begin{tabular}{|c|}
0.82625 \\
2 \\
\end{tabular} & \begin{tabular}{|c|}
86.281 \\
8 \\
\end{tabular} & \begin{tabular}{|c|}
86.28 \\
18 \\
\end{tabular} & 0 & 0 & 0 & 0 & \begin{tabular}{|c|}
0.76728 \\
9 \\
\end{tabular} & 2.18931 & \begin{tabular}{|c|}
0.05721 \\
3 \\
\end{tabular} & 1 \\
\hline 86 & 1 & 2 & 1 & 3 & 1 & 1 & & & \begin{tabular}{|c|}
0.75499 \\
6 \\
\end{tabular} & \begin{tabular}{|c|}
0.72348 \\
9 \\
\end{tabular} & -43.825 & -43.825 & \begin{tabular}{|c|}
0.78650 \\
2 \\
\end{tabular} & \begin{tabular}{|c|}
82.214 \\
6 \\
\end{tabular} & $\begin{array}{c}82.21 \\
46\end{array}$ & 0 & 0 & 0 & 0 & \begin{tabular}{|c|}
0.77767 \\
4
\end{tabular} & 2.98114 & \begin{tabular}{|c|}
0.51201 \\
3
\end{tabular} & 1 \\
\hline 87 & 1 & 2 & 1 & 3 & 1 & 14 & & & \begin{tabular}{|l|}
0.7548 \\
\end{tabular} & \begin{tabular}{|c|}
0.74790 \\
5 \\
\end{tabular} & -42.54 & -42.54 & \begin{tabular}{|c|}
0.76169 \\
5 \\
\end{tabular} & \begin{tabular}{|c|}
79.623 \\
8 \\
\end{tabular} & $\begin{array}{c}79.62 \\
38 \\
\end{array}$ & 0 & 0 & 0 & 0 & 0.76495 & 6.39223 & \begin{tabular}{|c|}
$\begin{array}{c}0.31202 \\
4\end{array}$ \\
\end{tabular} & 1 \\
\hline 88 & 1 & 1 & 1 & 3 & 1 & 9 & & & \begin{tabular}{|c|}
0.74971 \\
4 \\
\end{tabular} & 0.68816 & $\begin{array}{c}- \\
40.6816 \\
\end{array}$ & $\begin{array}{c}- \\
40.6816 \\
\end{array}$ & \begin{tabular}{|c|}
0.81126 \\
9
\end{tabular} & \begin{tabular}{|c|}
84.750 \\
4 \\
\end{tabular} & \begin{tabular}{|c|}
84.75 \\
04 \\
\end{tabular} & 0 & 0 & 0 & 0 & \begin{tabular}{|c|}
0.79096 \\
6
\end{tabular} & 2.22825 & \begin{tabular}{|c|}
0.61620 \\
5 \\
\end{tabular} & 1 \\
\hline 89 & 1 & 1 & 1 & 3 & 1 & 8 & & & \begin{tabular}{|c|}
0.74672 \\
7 \\
\end{tabular} & \begin{tabular}{|c|}
0.68368 \\
9 \\
\end{tabular} & \begin{tabular}{c|}
- \\
40.9207 \\
\end{tabular} & \begin{tabular}{c|}
- \\
40.9207 \\
\end{tabular} & \begin{tabular}{|c|}
0.80976 \\
4 \\
\end{tabular} & \begin{tabular}{|c|}
84.613 \\
3 \\
\end{tabular} & \begin{tabular}{|c|}
84.61 \\
33
\end{tabular} & 0 & 0 & 0 & 0 & \begin{tabular}{|c|}
0.80119 \\
5 \\
\end{tabular} & 2.85338 & \begin{tabular}{|c|}
0.64777 \\
8 \\
\end{tabular} & 1 \\
\hline 90 & 1 & 1 & 1 & 3 & 1 & 14 & & & 0.72364 & \begin{tabular}{|c|}
0.69382 \\
9 \\
\end{tabular} & $\mid-39.821$ & $\mid-39.821$ & \begin{tabular}{|c|}
0.75345 \\
2 \\
\end{tabular} & \begin{tabular}{|c|}
78.815 \\
3 \\
\end{tabular} & \begin{tabular}{|c|}
78.81 \\
53 \\
\end{tabular} & 0 & 0 & 0 & 0 & \begin{tabular}{|c|}
0.74858 \\
4 \\
\end{tabular} & 8.07904 & \begin{tabular}{|c|}
0.56018 \\
3
\end{tabular} & 1 \\
\hline 91 & 1 & 1 & 1 & 3 & 1 & 1 & & & \begin{tabular}{|c|}
0.72117 \\
9 \\
\end{tabular} & \begin{tabular}{|c|}
0.64577 \\
2 \\
\end{tabular} & \begin{tabular}{|c|}
- \\
39.4903 \\
\end{tabular} & \begin{tabular}{|c|}
- \\
39.4903 \\
\end{tabular} & \begin{tabular}{|c|}
0.79658 \\
6 \\
\end{tabular} & \begin{tabular}{|c|}
83.232 \\
3 \\
\end{tabular} & $\begin{array}{c}83.23 \\
23\end{array}$ & 0 & 0 & 0 & 0 & \begin{tabular}{|c|}
0.76379 \\
9 \\
\end{tabular} & 7.69629 & \begin{tabular}{|c|}
0.69705 \\
2 \\
\end{tabular} & 1 \\
\hline 92 & 1 & 2 & 1 & 3 & & & 1 & 1 & \begin{tabular}{|c|}
0.80988 \\
3 \\
\end{tabular} & \begin{tabular}{|c|}
0.78007 \\
3
\end{tabular} & $\begin{array}{c}- \\
42.2796 \\
\end{array}$ & $\begin{array}{c}- \\
42.2796 \\
\end{array}$ & \begin{tabular}{|c|}
0.83969 \\
3 \\
\end{tabular} & \begin{tabular}{|c|}
87.144 \\
9
\end{tabular} & \begin{tabular}{|c|}
87.14 \\
49
\end{tabular} & 0 & 0 & 0 & 0 & \begin{tabular}{|c|}
0.80965 \\
3
\end{tabular} & 3.02744 & \begin{tabular}{|c|}
0.10971 \\
9
\end{tabular} & 1 \\
\hline
\end{tabular}




\begin{tabular}{|c|c|c|c|c|c|c|c|c|c|c|c|c|c|c|c|c|c|c|c|c|c|c|c|}
\hline \begin{tabular}{|c} 
Templ \\
ate
\end{tabular} & $\begin{array}{c}\text { Isomer } \\
\text { Substra } \\
\text { te 7:1 }\end{array}$ & $\begin{array}{c}\text { Conf } \\
\text { Substra } \\
\text { te 7:1 }\end{array}$ & $\begin{array}{l}\text { Isomer } \\
\text { Substra } \\
\text { te 28:1 }\end{array}$ & \begin{tabular}{|c|} 
Conf \\
Substra \\
te 28:1
\end{tabular} & \begin{tabular}{|c|} 
Isomer \\
Substrat \\
e 27:1
\end{tabular} & \begin{tabular}{|c|} 
Conf \\
Substra \\
te $27: 1$
\end{tabular} & \begin{tabular}{|l|} 
Isomer \\
Substra \\
te 13:1
\end{tabular} & \begin{tabular}{|c|} 
Conf \\
Substra \\
te 13:1
\end{tabular} & \begin{tabular}{|c|} 
Similarit \\
$y$
\end{tabular} & \begin{tabular}{|c|} 
Field \\
Similarit \\
$y$
\end{tabular} & $\begin{array}{l}\text { Raw } \\
\text { Field } \\
\text { Score }\end{array}$ & $\begin{array}{c}\text { Penalis } \\
\text { ed Field } \\
\text { Score }\end{array}$ & \begin{tabular}{|c|} 
Shape \\
Similarit \\
$y$
\end{tabular} & \begin{tabular}{|c|} 
Raw \\
Shape \\
Score
\end{tabular} & $\begin{array}{c}\text { Penali } \\
\text { sed } \\
\text { Shape } \\
\text { Score }\end{array}$ & \begin{tabular}{|c|} 
Tot \\
al \\
Pen \\
alty
\end{tabular} & \begin{tabular}{|c|} 
Exclud \\
ed \\
Volum \\
e \\
Clash \\
Penalt \\
$y$ \\
\end{tabular} & \begin{tabular}{|c|} 
Atom \\
Distanc \\
e \\
Constrai \\
nt \\
Penalty
\end{tabular} & \begin{tabular}{|c|} 
Field \\
Value \\
Penalt \\
$y$
\end{tabular} & \begin{tabular}{|c|} 
Templat \\
e \\
Pairwis \\
e RMS \\
Similarit \\
y
\end{tabular} & \begin{tabular}{|c|} 
Templat \\
e RMS \\
Angle \\
Deviatio \\
$n$
\end{tabular} & \begin{tabular}{|c|} 
Templat \\
e RMS \\
Distanc \\
e \\
Deviatio \\
$n$
\end{tabular} & $\begin{array}{l}\text { Te } \\
\mathrm{mpl} \\
\text { ate } \\
\text { Den } \\
\text { sity }\end{array}$ \\
\hline 93 & 1 & 1 & 1 & 3 & & & 1 & 1 & \begin{tabular}{|c|}
0.79678 \\
6
\end{tabular} & \begin{tabular}{|c|}
0.74091 \\
5 \\
\end{tabular} & $\begin{array}{c}- \\
40.5027 \\
\end{array}$ & $\begin{array}{c}- \\
40.5027 \\
\end{array}$ & \begin{tabular}{|c|}
0.85265 \\
6
\end{tabular} & $\begin{array}{c}88.522 \\
8\end{array}$ & $\begin{array}{c}88.52 \\
28\end{array}$ & 0 & 0 & 0 & 0 & \begin{tabular}{|c|}
0.79826 \\
9
\end{tabular} & \begin{tabular}{|l|}
1.29187 \\
\end{tabular} & \begin{tabular}{|c|}
0.07096 \\
2
\end{tabular} & 1 \\
\hline 94 & 1 & 2 & 1 & 1 & & & 1 & 1 & 0.79464 & 0.74669 & $\begin{array}{c}- \\
42.6158 \\
\end{array}$ & $\begin{array}{c}- \\
42.6158 \\
\end{array}$ & \begin{tabular}{|c|}
0.84258 \\
9
\end{tabular} & $\begin{array}{c}87.462 \\
2\end{array}$ & $\begin{array}{c}87.46 \\
22\end{array}$ & 0 & 0 & 0 & 0 & \begin{tabular}{|c|}
0.79171 \\
9
\end{tabular} & 2.49893 & \begin{tabular}{|c|}
0.03571 \\
6 \\
\end{tabular} & 1 \\
\hline 95 & 1 & 2 & 1 & 2 & & & 1 & 1 & $\mid 0.79442$ & \begin{tabular}{|c|}
0.74594 \\
7
\end{tabular} & \begin{tabular}{|c|}
- \\
41.8048 \\
\end{tabular} & $\begin{array}{c}- \\
41.8048 \\
\end{array}$ & \begin{tabular}{|c|}
0.84289 \\
4
\end{tabular} & $\begin{array}{c}87.500 \\
5 \\
\end{array}$ & \begin{tabular}{|c|}
87.50 \\
05
\end{tabular} & 0 & 0 & 0 & 0 & \begin{tabular}{|c|}
0.78943 \\
6
\end{tabular} & 2.01151 & 0.05933 & 1 \\
\hline
\end{tabular}


Conformation hunting and molecule alignment

Conformations and alignments were then calculated and compared to the pharmacophore reference generated.

\begin{tabular}{|c|c|c|c|c|c|c|}
\hline \multicolumn{7}{|l|}{ Forge Processing } \\
\hline Conformation Hunt & Alignment & \multicolumn{2}{|c|}{ Build Model } & & & \\
\hline Calculation Method: & \multicolumn{3}{|c|}{ Accurate but Slow } & Save As... & Delete & Q \\
\hline \multicolumn{7}{|c|}{$\square$ Delete existing conformations } \\
\hline \multicolumn{7}{|c|}{$\checkmark$ Perform Conformation Hunt } \\
\hline \multicolumn{3}{|c|}{ Maximum number of conformations } & \multicolumn{2}{|l|}{200} & & 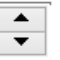 \\
\hline \multicolumn{3}{|c|}{ No. of high-T dynamics runs for flexible rings } & \multicolumn{2}{|l|}{10} & & 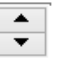 \\
\hline \multicolumn{3}{|c|}{ Gradient cutoff for conformer minimization } & \multicolumn{2}{|l|}{$0.100 \mathrm{kcal} / \mathrm{mol} / \mathrm{A}$} & & $\vec{\nabla}$ \\
\hline \multicolumn{3}{|c|}{ Filter duplicate conformers at RMS } & \multicolumn{2}{|l|}{$0.50 \mathrm{~A}$} & & 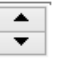 \\
\hline \multicolumn{3}{|l|}{ Energy window } & \multicolumn{2}{|l|}{$3.00 \mathrm{kcal} / \mathrm{mol}$} & & 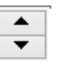 \\
\hline \multicolumn{3}{|c|}{ Acyclic secondary amide handling } & \multicolumn{2}{|l|}{ Force amides trans } & & $\boldsymbol{r}$ \\
\hline \multicolumn{3}{|c|}{ Remove boats and twist-boats } & $\square$ & & & \\
\hline \multicolumn{3}{|c|}{ Turn off Coulombic and attractive vdW forces } & $\square$ & & & \\
\hline \multicolumn{3}{|c|}{ Use external tool for conformation generation $\square$} & $\square$ & & & \\
\hline
\end{tabular}

All 64 molecules selected for conformation hunt and alignment. 
Forge Processing

Conformation Hunt Alignment Build Model

\begin{tabular}{l||l||l||} 
Calculation Method: Normal & Save As... & Delete
\end{tabular}

Delete existing alignments

$\checkmark$ Perform Alignment

Invert achiral imported confs $\square$

$\square$ Maximum-common-substructure conformers and alignment

Matching rules

Normal (element + hybridisation)

Require full ring matches

Substructure match SMARTS

Allow conformations to move

\section{Perform Scoring}

Take shortcuts in alignments

Score method for multiple references

Weighted Average

Reference weights

Reference 1

2

3

4

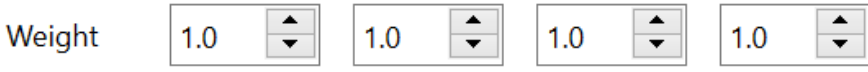

$\begin{array}{llll}\text { Weight } \% & 25.0 \% & 25.0 \% & 25.0 \%\end{array}$

Fraction of score from shape similarity

\begin{tabular}{|l|l|}
\hline 0.50 & $\vdots$ \\
\hline 0.50 & \\
\hline
\end{tabular}

Reference into $\mathrm{db}$ fieldpoints weight

0.50

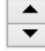

All 64 molecules selected for conformation hunt and alignment. 


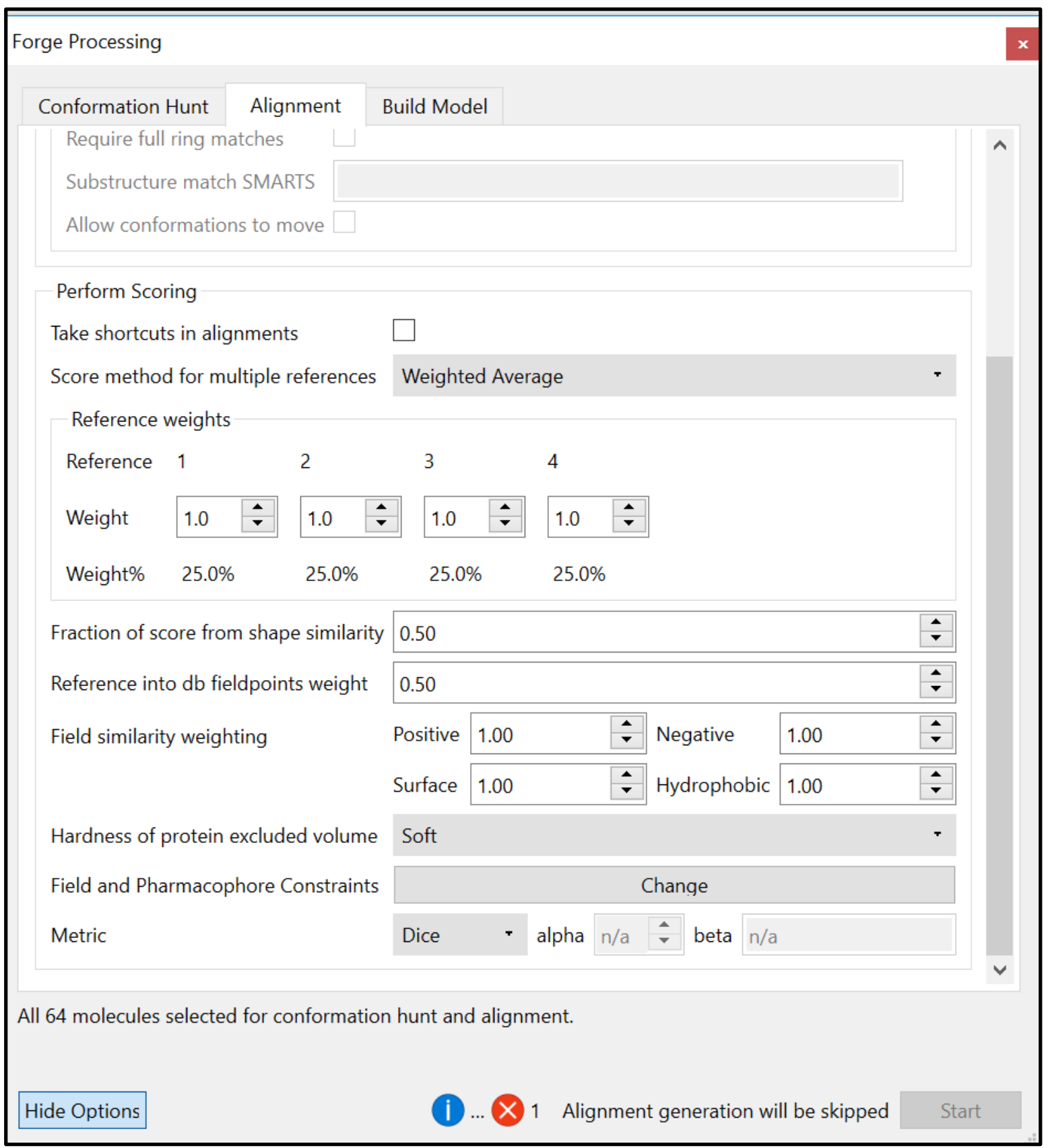

The following pharmacophore constraint was applied to ensure alignments scored highest if they overlapped the carbonyl with the reference pharmacophore, acceptor 10.0 strength. 


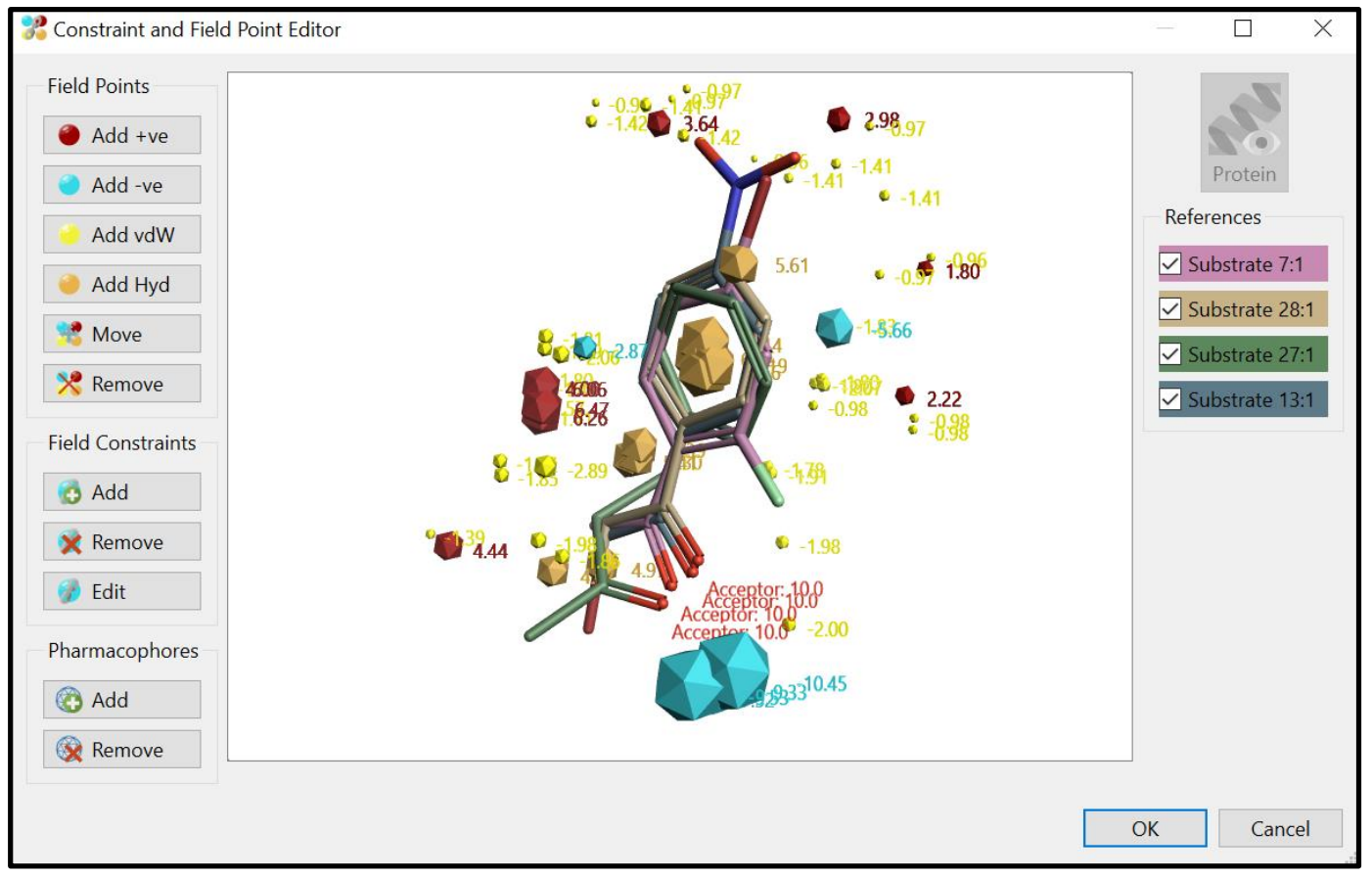

All alignments were manually checked and adjusted in the Edit Molecule tool if necessary

Categorising activity

Method

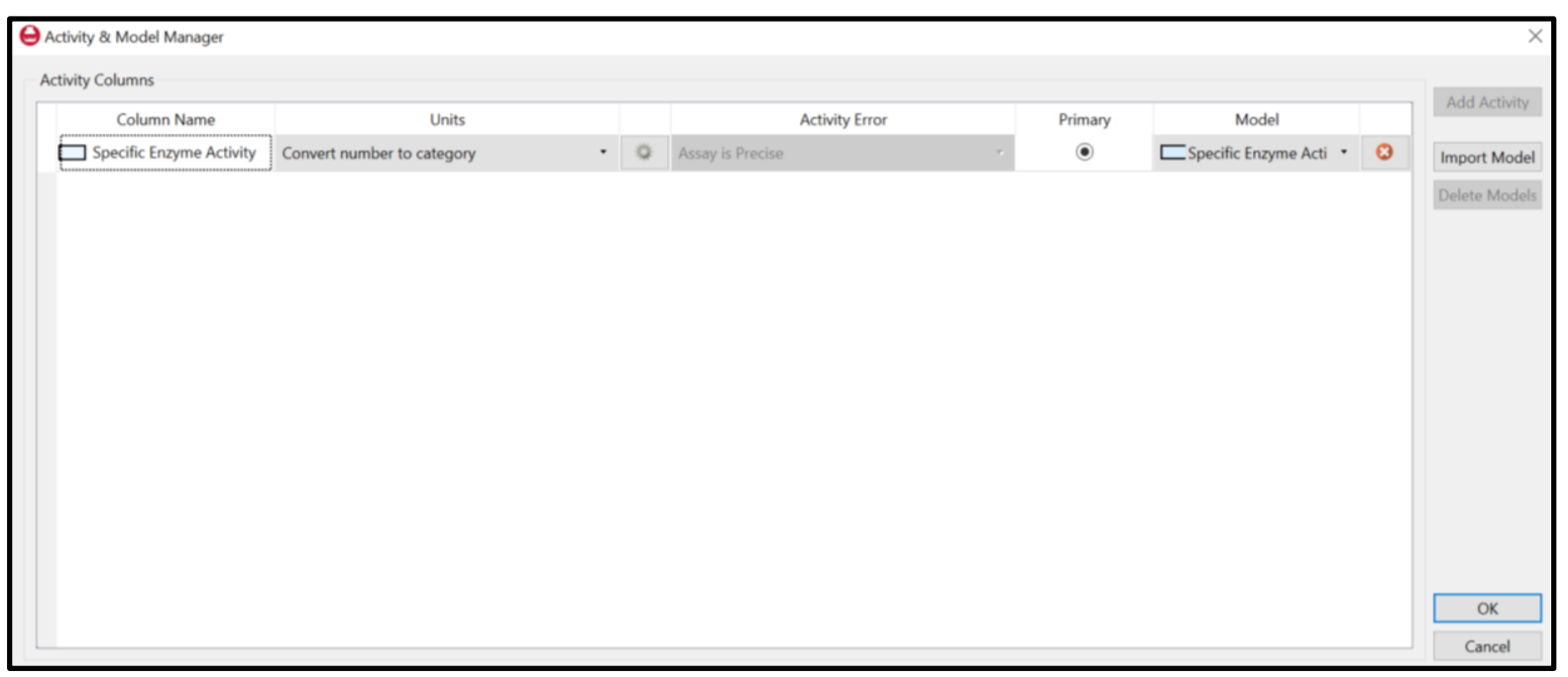

Data set partitioned (activity stratified) and specific enzyme activity categorised as below

Results

\begin{tabular}{|c|c|c|}
\hline Category & Specific Enzyme Activity range/ mUnits & Number of molecules \\
\hline 1 & $<30$ & 14 \\
\hline 2 & $30<x<90$ & 12 \\
\hline 3 & $>90$ & 25 \\
\hline
\end{tabular}

51 molecules in training set

13 molecules in test set 
Model building

Method

Forge's automatic model building settings were used to find the best fit initially, with small adjustments made to test set size, number of folds for cross-validation and global optimisation time limit in order to find the best fit model, with the best fit model detailed in the logs below.

Results

\section{Model log}

Building model at Thu Apr 16 13:08:09 2020

Building sample point list from 51 training set molecules

Pre-cluster: 884 points

Post-cluster: 140 points

Process config 'SVM Classification'

Sample point minimum distance threshold: 1

Type of machine learning model: Support Vector Machine (SVM) Classification

Use electrostatic fields in model building: true

Use hydrophobic (bulk grease) field in model building: false

Use references in generating field samples: false

Use steric (vdW) field in model building: false

Use volume indicator field in model building: true

Weighting: weight molecules according to their similarity: false

Cache size (MB): 200

Global optimization - maximum C: 1000

Global optimization - maximum gamma: 0.1

Global optimization - maximum number of iterations: 50

Global optimization - minimum C: 0.1

Global optimization - minimum gamma: 1e-5

Global optimization - time limit (s): 3600

Number of folds for cross-validation: 5

Perform parameter optimization: true

Finished building model at Thu Apr 16 13:08:10 2020

Support Vector Machine (SVM) classification model (radial basis function kernel) parameters:

Gamma: 6.14060e-3 


\section{C: $7.14352 \mathrm{e}+1$}

Number of basis vectors for 1-2 classifier: 26

Number of basis vectors for 1-3 classifier: 30

Number of basis vectors for 2-3 classifier: 35

Statistics for predictions from full model on 51 compds:

Confusion matrix:

Predicted

123

Actual 11400

20120

30025

Informedness (Bookmaker's): 1.000

F1 statistic: 1.000

Mean precision: 1.000

Mean recall: 1.000

Precision Recall Youden's J

Class 11.0001 .0001 .000

Class 21.0001 .0001 .000

Class 31.0001 .0001 .000

Statistics for predictions from cross-validation on 51 compds:

Confusion matrix:

Predicted

123

Actual 1613

2334

31321

Informedness (Bookmaker's): 0.442 
F1 statistic: 0.586

Mean precision: 0.593

Mean recall: 0.580

Precision Recall Youden's J

Class 10.6000 .6000 .486

Class 20.4290 .3000 .186

Class 30.7500 .8400 .490

Note that the sum of the elements of the confusion matrix from k-fold cross-validation may be less than the number of training molecules if the number of molecules in a class is not an even multiple of the number of folds

Statistics for test set predictions from full model on 13 compds:

Confusion matrix:

Predicted

123

Actual 1210

2220

3015

Informedness (Bookmaker's): 0.550

F1 statistic: 0.667

Mean precision: 0.667

Mean recall: 0.667

Precision Recall Youden's J

Class 10.5000 .6670 .467

Class 20.5000 .5000 .278

Class 31.0000 .8330 .833

Molecule list for creation of QSAR descriptor matrix uses training set molecules:

Molecule 'Substrate 9:1' activity 2 similarity 0.768662 
Molecule 'Substrate 28:1 (1)' activity 3 similarity 0.802714

Molecule 'Substrate 24:1' activity 3 similarity 0.775898

Molecule 'Substrate R:1' activity 1 similarity 0.505279

Molecule 'Substrate 3:1' activity 3 similarity 0.804482

Molecule 'Substrate 36:1' activity 3 similarity 0.713799

Molecule 'Substrate 30:1' activity 2 similarity 0.667505

Molecule 'Substrate 13:1 (1)' activity 3 similarity 0.774402

Molecule 'Substrate Z:1' activity 3 similarity 0.773946

Molecule 'Substrate 21:1' activity 1 similarity 0.692405

Molecule 'Substrate $15: 1$ ' activity 2 similarity 0.718686

Molecule 'Substrate M:1' activity 3 similarity 0.709612

Molecule 'Substrate 33:1' activity 1 similarity 0.718807

Molecule 'Substrate 27:1 (1)' activity 3 similarity 0.764832

Molecule 'Substrate AD:1' activity 1 similarity 0.733445

Molecule 'Substrate 34:1' activity 1 similarity 0.76425

Molecule 'Substrate 22:1' activity 1 similarity 0.761697

Molecule 'Substrate 16:1' activity 2 similarity 0.672556

Molecule 'Substrate AA:1' activity 3 similarity 0.716728

Molecule 'Substrate L:1' activity 3 similarity 0.733287

Molecule 'Substrate 2:1' activity 2 similarity 0.774585

Molecule 'Substrate 20:1' activity 3 similarity 0.700799

Molecule 'Substrate AF:1' activity 3 similarity 0.708141

Molecule 'Substrate D:1' activity 1 similarity 0.56784

Molecule 'Substrate K:1' activity 2 similarity 0.524355

Molecule 'Substrate S:1' activity 1 similarity 0.654308

Molecule 'Substrate 5:1' activity 1 similarity 0.755082

Molecule 'Substrate 35:1' activity 2 similarity 0.71247

Molecule 'Substrate Al:1' activity 1 similarity 0.722646

Molecule 'Substrate AJ:1' activity 3 similarity 0.783419

Molecule 'Substrate 19:1' activity 3 similarity 0.772806

Molecule 'Substrate 31:1' activity 3 similarity 0.800635 
Molecule 'Substrate AB:1' activity 3 similarity 0.679284

Molecule 'Substrate 11:1' activity 3 similarity 0.75562

Molecule 'Substrate 4:1' activity 3 similarity 0.768086

Molecule 'Substrate AG:1' activity 2 similarity 0.595191

Molecule 'Substrate I:1' activity 1 similarity 0.431222

Molecule 'Substrate $18: 1$ ' activity 2 similarity 0.706099

Molecule 'Substrate 1:1' activity 3 similarity 0.751198

Molecule 'Substrate 6:1' activity 3 similarity 0.770132

Molecule 'Substrate G:1' activity 2 similarity 0.683298

Molecule 'Substrate J:1' activity 3 similarity 0.724922

Molecule 'Substrate 12:1' activity 3 similarity 0.748498

Molecule 'Substrate P:1' activity 1 similarity 0.663946

Molecule 'Substrate $14: 1$ ' activity 2 similarity 0.725131

Molecule 'Substrate AE:1' activity 3 similarity 0.597768

Molecule 'Substrate 0:1' activity 3 similarity 0.738688

Molecule 'Substrate C:1' activity 1 similarity 0.694372

Molecule 'Substrate 26:1' activity 3 similarity 0.648241

Molecule 'Substrate 8:1' activity 1 similarity 0.785681

Molecule 'Substrate 37:1' activity 2 similarity 0.740522 


\section{Data export from Forge}

\section{Molecule data export}

\begin{tabular}{|c|c|c|c|c|c|c|c|c|c|c|c|c|c|c|c|c|c|c|c|c|c|c|c|c|c|}
\hline Title & $\begin{array}{c}\text { Radial } \\
\text { Plot }\end{array}$ & $\begin{array}{l}\text { Activity } \\
\text { (Specific } \\
\text { Enzyme } \\
\text { Activity) }\end{array}$ & $\begin{array}{l}\text { Support Vector Machine } \\
\text { Classification (Specific } \\
\text { Enzyme Activity) }\end{array}$ & $\begin{array}{c}\text { Alignment } \\
\text { Chosen }\end{array}$ & Sim & FSim & FScore & FScore+P & SSim & SScore & SScore+P & $\begin{array}{l}\text { Excl } \\
\text { Vol } \\
\text { Pen }\end{array}$ & $\begin{array}{c}\text { Field } \\
\text { Pen }\end{array}$ & Confs & Conf\# & Alns & $\mathrm{MW}$ & $\begin{array}{c}\text { \#Ato } \\
\text { ms }\end{array}$ & 2D Sim & SlogP & TPSA & $\begin{array}{c}\text { Flexibi } \\
\text { lity }\end{array}$ & \#RB & Rof5 & $\begin{array}{c}\text { Exp. } \\
\text { Specific } \\
\text { Enzyme } \\
\text { Activity }\end{array}$ \\
\hline $\begin{array}{c}\text { Substrate } \\
7: 1\end{array}$ & 0.482 & 3 & & $n / a$ & 0 & 0 & 0 & 0 & 0 & 0 & 0 & 0 & 0 & 0 & $n / a$ & 0 & 217 & 11 & 0.422 & 3.1 & 17.1 & 0.3 & 1 & 0 & 366 \\
\hline $\begin{array}{c}\text { Substrate } \\
28: 1\end{array}$ & 0.495 & 3 & & $\mathrm{n} / \mathrm{a}$ & 0 & 0 & 0 & 0 & 0 & 0 & 0 & 0 & 0 & 0 & $\mathrm{n} / \mathrm{a}$ & 0 & 199 & 10 & 0.455 & 2.3 & 17.1 & 1.3 & 2 & 0 & 337.2 \\
\hline $\begin{array}{c}\text { Substrate } \\
27: 1\end{array}$ & 0.495 & 3 & & $\mathrm{n} / \mathrm{a}$ & 0 & 0 & 0 & 0 & 0 & 0 & 0 & 0 & 0 & 0 & $\mathrm{n} / \mathrm{a}$ & 0 & 148.2 & 11 & 0.404 & 2.2 & 17.1 & 3 & 3 & 0 & 364 \\
\hline $\begin{array}{c}\text { Substrate } \\
13: 1 \\
\end{array}$ & 0.744 & 3 & & $\mathrm{n} / \mathrm{a}$ & 0 & 0 & 0 & 0 & 0 & 0 & 0 & 0 & 0 & 0 & $\mathrm{n} / \mathrm{a}$ & 0 & 165.1 & 12 & 0.426 & 1.7 & 62.9 & 0.5 & 2 & 0 & 593.1 \\
\hline $\begin{array}{c}\text { Substrate } \\
28: 1 \text { (1) }\end{array}$ & 0.687 & 3 & 3 & 1 & 0.803 & 0.813 & -47.096 & $\mid-45.017$ & 0.792 & 87.724 & 81.488 & 0 & 0 & 2 & 1 & 2 & 199 & 10 & 0.455 & 2.3 & 17.1 & 1.3 & 2 & 0 & 337.2 \\
\hline $\begin{array}{c}\text { Substrate } \\
24: 1\end{array}$ & 0.652 & 3 & 3 & 1 & 0.776 & 0.755 & -40.977 & -38.923 & 0.797 & 91.71 & 85.548 & 0 & 0 & 2 & 2 & 2 & 190.6 & 12 & 0.244 & 2.9 & 17.1 & 1.3 & 2 & 0 & 111.7 \\
\hline $\begin{array}{c}\text { Substrate } \\
36: 1\end{array}$ & 0.576 & 3 & 3 & 1 & 0.714 & 0.659 & -35.279 & -33.075 & 0.769 & 79.895 & 73.281 & 0 & 0 & 2 & 1 & 10 & 126.2 & 9 & 0.047 & 2.2 & 17.1 & 2 & 1 & 0 & 111.6 \\
\hline $\begin{array}{c}\text { Substrate } \\
30: 1\end{array}$ & 0.48 & 2 & 2 & 1 & 0.668 & 0.693 & -43.748 & -41.507 & 0.642 & 75.874 & 69.152 & 0 & 0 & 108 & 101 & 10 & 156.3 & 11 & 0.049 & 3.3 & 17.1 & 7 & 7 & 0 & 37.1 \\
\hline $\begin{array}{c}\text { Substrate } \\
\mathrm{Z}: 1\end{array}$ & 0.702 & 3 & 3 & 1 & 0.774 & 0.743 & -47.745 & -45.633 & 0.805 & 87.659 & 81.323 & 0 & 0 & 2 & 2 & 2 & 150.2 & 11 & 0.31 & 1.9 & 26.3 & 0.8 & 2 & 0 & 222.1 \\
\hline $\begin{array}{c}\text { Substrate } \\
21: 1 \\
\end{array}$ & 0.654 & 1 & 1 & 1 & 0.692 & 0.626 & -36.301 & -34.103 & 0.759 & 86.257 & 79.662 & 0 & 0 & 3 & 3 & 3 & 159.2 & 12 & 0.287 & 2.4 & 32.9 & 0.3 & 1 & 0 & 0 \\
\hline $\begin{array}{c}\text { Substrate } \\
15: 1\end{array}$ & 0.633 & 2 & 2 & 1 & 0.719 & 0.738 & -45.742 & -43.614 & 0.699 & 84.598 & 78.216 & 0 & 0 & 3 & 1 & 3 & 178.2 & 13 & 0.235 & 2.5 & 26.3 & 1.8 & 3 & 0 & 64 \\
\hline $\begin{array}{c}\text { Substrate } \\
\mathrm{M}: 1\end{array}$ & 0.818 & 3 & 3 & 1 & 0.71 & 0.7 & -48.353 & -46.273 & 0.72 & 88.297 & 82.058 & 0 & 0 & 5 & 2 & 5 & 213.3 & 14 & 0.25 & 1.3 & 63.2 & 1 & 3 & 0 & 203.3 \\
\hline $\begin{array}{c}\text { Substrate } \\
33: 1 \\
\end{array}$ & 0.825 & 1 & 1 & 1 & 0.719 & 0.649 & -45.175 & -43.159 & 0.789 & 88.028 & 81.98 & 0 & 0 & 5 & 4 & 5 & 165.2 & 12 & 0.277 & 0.8 & 49.3 & 2.8 & 4 & 0 & 17.4 \\
\hline $\begin{array}{c}\text { Substrate } \\
27: 1(1)\end{array}$ & 0.639 & 3 & 3 & 1 & 0.765 & 0.761 & -40.518 & -38.252 & 0.768 & 85.456 & 78.659 & 0 & 0 & 2 & 2 & 2 & 148.2 & 11 & 0.404 & 2.2 & 17.1 & 3 & 3 & 0 & 364 \\
\hline $\begin{array}{c}\text { Substrate } \\
34: 1 \\
\end{array}$ & 0.782 & 1 & 1 & 1 & 0.764 & 0.741 & -41.098 & -38.965 & 0.788 & 81.24 & 74.843 & 0 & 0 & 4 & 4 & 4 & 136.2 & 10 & 0.316 & 1.6 & 37.3 & 0.8 & 2 & 0 & 0 \\
\hline $\begin{array}{c}\text { Substrate } \\
16: 1\end{array}$ & 0.728 & 2 & 2 & 1 & 0.673 & 0.651 & -41.438 & -39.393 & 0.694 & 88.618 & 82.484 & 0 & 0 & 6 & 1 & 6 & 210.2 & 15 & 0.154 & 1.9 & 44.8 & 1.8 & 4 & 0 & 89.9 \\
\hline $\begin{array}{c}\text { Substrate } \\
\text { L:1 }\end{array}$ & 0.681 & 3 & 3 & 1 & 0.733 & 0.701 & -40.434 & -38.37 & 0.766 & 88.008 & 81.816 & 0 & 0 & 2 & 2 & 2 & 189.1 & 13 & 0.192 & 2.3 & 30 & 0.3 & 2 & 0 & 210.2 \\
\hline $\begin{array}{c}\text { Substrate } \\
2: 1\end{array}$ & 0.796 & 2 & 2 & 1 & 0.775 & 0.729 & -47.371 & -45.323 & 0.82 & 83.976 & 77.831 & 0 & 0 & 2 & 2 & 2 & 136.2 & 10 & 0.347 & 1.6 & 37.3 & 0.8 & 2 & 0 & 31.5 \\
\hline $\begin{array}{c}\text { Substrate } \\
20: 1\end{array}$ & 0.75 & 3 & 3 & 1 & 0.701 & 0.615 & -31.302 & -29.276 & 0.786 & 76.041 & 69.961 & 0 & 0 & 2 & 2 & 2 & 122.1 & 9 & 0.214 & 0.7 & 42.8 & 0.3 & 1 & 0 & 185.1 \\
\hline $\begin{array}{c}\text { Substrate } \\
\mathrm{K}: 1\end{array}$ & 0.74 & 2 & 2 & 1 & 0.524 & 0.471 & -33.606 & -29.816 & 0.578 & 78.104 & 66.732 & 0 & 0 & 1 & 1 & 1 & 207.2 & 15 & 0.239 & 0.8 & 80.4 & 4.5 & 6 & 0 & 62.2 \\
\hline
\end{tabular}




\begin{tabular}{|c|c|c|c|c|c|c|c|c|c|c|c|c|c|c|c|c|c|c|c|c|c|c|c|c|c|}
\hline Title & $\begin{array}{l}\text { Radial } \\
\text { Plot }\end{array}$ & $\begin{array}{l}\text { Activity } \\
\text { (Specific } \\
\text { Enzyme } \\
\text { Activity) } \\
\end{array}$ & $\begin{array}{l}\text { Support Vector Machine } \\
\text { Classification (Specific } \\
\text { Enzyme Activity) }\end{array}$ & $\begin{array}{c}\text { Alignment } \\
\text { Chosen }\end{array}$ & Sim & FSim & FScore & FScore+P & SSim & SScore & SScore+P & $\begin{array}{l}\text { Excl } \\
\text { Vol } \\
\text { Pen }\end{array}$ & $\begin{array}{c}\text { Field } \\
\text { Pen }\end{array}$ & Confs & Conf\# & Alns & MW & $\begin{array}{c}\text { \#Ato } \\
\text { ms }\end{array}$ & 2D Sim & $S \operatorname{Slog} P$ & TPSA & $\begin{array}{c}\text { Flexibi } \\
\text { lity }\end{array}$ & \#RB & Rof5 & $\begin{array}{c}\text { Exp. } \\
\text { Specific } \\
\text { Enzyme } \\
\text { Activity }\end{array}$ \\
\hline $\begin{array}{c}\text { Substrate } \\
\mathrm{S}: 1\end{array}$ & 0.716 & 1 & 1 & 1 & 0.654 & 0.599 & -31.05 & -28.23 & 0.71 & 69.315 & 60.853 & 0 & 0 & 1 & 1 & 1 & 110.1 & 8 & 0.169 & 0.6 & 45.8 & 0.3 & 1 & 0 & 20.7 \\
\hline $\begin{array}{c}\text { Substrate } \\
\text { Al:1 }\end{array}$ & 0.815 & 1 & 1 & 1 & 0.723 & 0.693 & -43.518 & -41.377 & 0.753 & 92.733 & 86.31 & 0 & 0 & 3 & 3 & 3 & 260 & 14 & 0.256 & 1.8 & 83.1 & 2 & 4 & 0 & 0 \\
\hline $\begin{array}{c}\text { Substrate } \\
\text { AJ:1 }\end{array}$ & 0.662 & 3 & 3 & 1 & 0.783 & 0.768 & -46.202 & -44.141 & 0.799 & 91.231 & 85.049 & 0 & 0 & 2 & 1 & 2 & 246 & 10 & 0.347 & 2.8 & 17.1 & 0.3 & 1 & 0 & 116.9 \\
\hline $\begin{array}{c}\text { Substrate } \\
19: 1\end{array}$ & 0.733 & 3 & 3 & 1 & 0.773 & 0.728 & -38.784 & -36.769 & 0.818 & 82.973 & 76.928 & 0 & 0 & 2 & 1 & 2 & 139.1 & 10 & 0.275 & 1.7 & 30 & 0.3 & 1 & 0 & 136.6 \\
\hline $\begin{array}{c}\text { Substrate } \\
A B: 1\end{array}$ & 0.659 & 3 & 3 & 1 & 0.679 & 0.667 & -40.294 & -38.262 & 0.691 & 81.984 & 75.886 & 0 & 0 & 5 & 5 & 5 & 180.2 & 13 & 0.174 & 1.9 & 35.5 & 1.3 & 3 & 0 & 362.6 \\
\hline $\begin{array}{c}\text { Substrate } \\
11: 1\end{array}$ & 0.756 & 3 & 3 & 1 & 0.756 & 0.739 & -42.193 & -40.101 & 0.773 & 85.701 & 79.424 & 0 & 0 & 2 & 2 & 2 & 164.2 & 12 & 0.264 & 1.6 & 35.5 & 0.3 & 1 & 0 & 188.5 \\
\hline $\begin{array}{c}\text { Substrate } \\
4: 1 \\
\end{array}$ & 0.643 & 3 & 3 & 1 & 0.768 & 0.793 & -48.674 & -46.639 & 0.743 & 82.518 & 76.412 & 0 & 0 & 2 & 1 & 2 & 199 & 10 & 0.361 & 2.7 & 17.1 & 0.3 & 1 & 0 & 141.6 \\
\hline \begin{tabular}{|c|} 
Substrate \\
AG:1 \\
\end{tabular} & 0.621 & 2 & 2 & 1 & 0.595 & 0.573 & -46.252 & -44.208 & 0.617 & 89.646 & 83.515 & 0 & 0 & 2 & 1 & 2 & 246.1 & 18 & 0.148 & 3 & 35.5 & 0.8 & 2 & 0 & 87 \\
\hline Substrate I:1 & 0.62 & 1 & 1 & 1 & 0.431 & 0.336 & -20.446 & -16.33 & 0.526 & 60.942 & 48.595 & 0 & 0 & 1 & 1 & 1 & 124.1 & 9 & 0.167 & 0.6 & 34.9 & 0.3 & 1 & 0 & 20.7 \\
\hline $\begin{array}{c}\text { Substrate } \\
F: 1\end{array}$ & 0.498 & 1 & 1 & 1 & 0.554 & 0.525 & -29.559 & -27.486 & 0.584 & 61.223 & 55.004 & 0 & 0 & 1 & 1 & 10 & 125.2 & 9 & 0.039 & 0.3 & 20.3 & 1.4 & 0 & 0 & 23.4 \\
\hline $\begin{array}{c}\text { Substrate } \\
39: 1\end{array}$ & 0.652 & 2 & 1 & 1 & 0.775 & 0.798 & -43.547 & -41.531 & 0.753 & 83.615 & 77.567 & 0 & 0 & 2 & 2 & 2 & 199 & 10 & 0.352 & 2.7 & 17.1 & 0.3 & 1 & 0 & 39.5 \\
\hline $\begin{array}{c}\text { Substrate } \\
\text { AC: } 1\end{array}$ & 0.774 & 1 & 2 & 1 & 0.72 & 0.719 & -47.941 & -45.886 & 0.721 & 87.289 & 81.123 & 0 & 0 & 2 & 2 & 2 & 204.1 & 12 & 0.19 & 2.8 & 43.1 & 0.3 & 1 & 0 & 0 \\
\hline $\begin{array}{c}\text { Substrate } \\
\mathrm{AH}: 1\end{array}$ & 0.708 & 3 & 3 & 1 & 0.753 & 0.695 & -41.128 & -39.087 & 0.81 & 88.355 & 82.233 & 0 & 0 & 2 & 2 & 2 & 200 & 10 & 0.296 & 2.1 & 30 & 0.3 & 1 & 0 & 268.7 \\
\hline $\begin{array}{c}\text { Substrate } \\
7: 1(1) \\
\end{array}$ & 0.679 & 3 & 3 & 1 & 0.807 & 0.812 & -43.683 & -41.616 & 0.803 & 91.771 & 85.569 & 0 & 0 & 2 & 1 & 2 & 217 & 11 & 0.422 & 3.1 & 17.1 & 0.3 & 1 & 0 & 366 \\
\hline $\begin{array}{c}\text { Substrate } \\
17: 1\end{array}$ & 0.717 & 3 & 3 & 1 & 0.76 & 0.724 & -39.187 & -37.112 & 0.796 & 78.457 & 72.234 & 0 & 0 & 2 & 1 & 2 & 121.1 & 9 & 0.292 & 1.3 & 30 & 0.3 & 1 & 0 & 162.6 \\
\hline $\begin{array}{c}\text { Substrate } \\
10: 1\end{array}$ & 0.676 & 2 & 1 & 1 & 0.753 & 0.756 & -43.545 & -41.486 & 0.751 & 82.035 & 75.859 & 0 & 0 & 2 & 2 & 2 & 150.2 & 11 & 0.288 & 1.9 & 26.3 & 0.8 & 2 & 0 & 83 \\
\hline $\begin{array}{c}\text { Substrate } \\
25: 1\end{array}$ & 0.675 & 3 & 3 & 1 & 0.794 & 0.776 & -43.077 & -41.002 & 0.812 & 89.85 & 83.626 & 0 & 0 & 2 & 2 & 2 & 199 & 10 & 0.393 & 2.7 & 17.1 & 0.3 & 1 & 0 & 158.2 \\
\hline $\begin{array}{c}\text { Substrate } \\
\mathrm{N}: 1\end{array}$ & 0.773 & 3 & 2 & 1 & 0.733 & 0.701 & -38.575 & -36.541 & 0.765 & 81.633 & 75.529 & 0 & 0 & 2 & 1 & 2 & 145.2 & 11 & 0.283 & 1.8 & 40.9 & 1.3 & 1 & 0 & 173.4 \\
\hline $\begin{array}{c}\text { Substrate } \\
6: 1\end{array}$ & 0.632 & 3 & 3 & 1 & 0.77 & 0.752 & -42.815 & -40.752 & 0.788 & 90.147 & 83.957 & 0 & 0 & 2 & 2 & 2 & 217 & 11 & 0.338 & 3.1 & 17.1 & 0.3 & 1 & 0 & 242.4 \\
\hline $\begin{array}{c}\text { Substrate } \\
\text { G:1 }\end{array}$ & 0.536 & 2 & 2 & 1 & 0.683 & 0.656 & -43.716 & -41.383 & 0.711 & 78.846 & 71.848 & 0 & 0 & 3 & 1 & 3 & 146.2 & 11 & 0.289 & 2.2 & 17.1 & 0.5 & 2 & 0 & 62.1 \\
\hline $\begin{array}{c}\text { Substrate } \\
12: 1\end{array}$ & 0.669 & 3 & 3 & 1 & 0.748 & 0.726 & -48.61 & -46.517 & 0.771 & 88.129 & 81.849 & 0 & 0 & 4 & 4 & 4 & 164.2 & 12 & 0.312 & 2.3 & 26.3 & 1.8 & 3 & 0 & 195.8 \\
\hline $\begin{array}{c}\text { Substrate } \\
\mathrm{P}: 1\end{array}$ & 0.621 & 1 & 1 & 1 & 0.664 & 0.622 & -40.443 & -38.399 & 0.706 & 83.46 & 77.33 & 0 & 0 & 2 & 1 & 2 & 176.2 & 13 & 0.215 & 1.2 & 33.2 & 0.8 & 3 & 0 & 0 \\
\hline $\begin{array}{c}\text { Substrate } \\
\mathrm{AE}: 1\end{array}$ & 0.497 & 3 & 3 & 1 & 0.598 & 0.586 & -29.897 & -27.819 & 0.609 & 55.208 & 48.974 & 0 & 0 & 2 & 1 & 10 & 84.1 & 6 & 0.062 & 1 & 17.1 & 1 & 1 & 0 & 98.2 \\
\hline
\end{tabular}




\begin{tabular}{|c|c|c|c|c|c|c|c|c|c|c|c|c|c|c|c|c|c|c|c|c|c|c|c|c|c|}
\hline Title & $\begin{array}{l}\text { Radial } \\
\text { Plot }\end{array}$ & $\begin{array}{l}\text { Activity } \\
\text { (Specific } \\
\text { Enzyme } \\
\text { Activity) }\end{array}$ & $\begin{array}{l}\text { Support Vector Machine } \\
\text { Classification (Specific } \\
\text { Enzyme Activity) }\end{array}$ & $\begin{array}{c}\text { Alignment } \\
\text { Chosen }\end{array}$ & Sim & FSim & FScore & FScore+P & SSim & SScore & SScore+P & $\begin{array}{l}\text { Excl } \\
\text { Vol } \\
\text { Pen }\end{array}$ & $\begin{array}{l}\text { Field } \\
\text { Pen }\end{array}$ & Confs & Conf\# & Alns & MW & $\begin{array}{c}\text { \#Ato } \\
\text { ms }\end{array}$ & 2D Sim & SlogP & TPSA & $\begin{array}{c}\text { Flexibi } \\
\text { lity }\end{array}$ & \#RB & Rof5 & $\begin{array}{c}\text { Exp. } \\
\text { Specific } \\
\text { Enzyme } \\
\text { Activity }\end{array}$ \\
\hline $\begin{array}{c}\text { Substrate } \\
\mathrm{C}: 1\end{array}$ & 0.667 & 1 & 1 & 1 & 0.694 & 0.62 & -36.545 & -34.141 & 0.768 & 84.975 & 77.762 & 0 & 0 & 2 & 2 & 2 & 158.2 & 12 & 0.284 & 1.4 & 34.1 & 0.2 & 0 & 0 & 0 \\
\hline $\begin{array}{c}\text { Substrate } \\
8: 1\end{array}$ & 0.809 & 1 & 1 & 1 & 0.786 & 0.766 & -43.138 & -41.108 & 0.806 & 91.355 & 85.263 & 0 & 0 & 3 & 3 & 3 & 215 & 11 & 0.345 & 2.4 & 37.3 & 0.8 & 2 & 0 & 27.2 \\
\hline $\begin{array}{c}\text { Substrate } \\
37: 1\end{array}$ & 0.608 & 2 & 2 & 1 & 0.741 & 0.708 & -48.004 & -45.948 & 0.773 & 90.664 & 84.498 & 0 & 0 & 2 & 2 & 2 & 170.2 & 13 & 0.309 & 3 & 17.1 & 0.3 & 1 & 0 & 54 \\
\hline $\begin{array}{c}\text { Substrate } \\
23: 1\end{array}$ & 0.394 & 2 & 2 & 1 & 0.662 & 0.689 & -40.906 & -38.873 & 0.635 & 85.058 & 78.959 & 0 & 0 & 3 & 1 & 3 & 256.1 & 17 & 0.114 & 3.9 & 17.1 & 0.3 & 3 & 0 & 57.3 \\
\hline $\begin{array}{c}\text { Substrate } \\
32: 1\end{array}$ & 0.721 & 3 & 3 & 1 & 0.764 & 0.712 & -41.115 & -39.078 & 0.816 & 87.07 & 80.961 & 0 & 0 & 3 & 1 & 3 & 155.6 & 10 & 0.26 & 2 & 30 & 0.3 & 1 & 0 & 92 \\
\hline $\begin{array}{c}\text { Substrate } \\
29: 1\end{array}$ & 0.518 & 1 & 1 & 1 & 0.67 & 0.656 & -43.704 & -41.673 & 0.684 & 83.304 & 77.21 & 0 & 0 & 3 & 1 & 3 & 182.2 & 14 & 0.215 & 2.9 & 17.1 & 0.5 & 2 & 0 & 14.3 \\
\hline $\begin{array}{c}\text { Substrate } \\
9: 1\end{array}$ & 0.837 & 2 & 2 & 1 & 0.769 & 0.72 & -46.844 & -44.794 & 0.817 & 84.046 & 77.897 & 0 & 0 & 2 & 2 & 2 & 135.2 & 10 & 0.347 & 1.5 & 43.1 & 0.3 & 1 & 0 & 80.4 \\
\hline $\begin{array}{c}\text { Substrate } \\
\text { R:1 }\end{array}$ & 0.742 & 1 & 1 & 1 & 0.505 & 0.449 & -38.884 & -32.61 & 0.561 & 90.439 & 71.618 & 0 & 0 & 82 & 71 & 10 & 232.3 & 17 & 0.176 & 1.9 & 54.1 & 3.5 & 4 & 0 & 21.7 \\
\hline $\begin{array}{c}\text { Substrate } \\
3: 1\end{array}$ & 0.688 & 3 & 3 & 1 & 0.804 & 0.79 & -38.509 & -36.433 & 0.819 & 84.477 & 78.247 & 0 & 0 & 2 & 2 & 2 & 138.1 & 10 & 0.363 & 2.3 & 17.1 & 0.3 & 1 & 0 & 122.1 \\
\hline $\begin{array}{c}\text { Substrate } \\
13: 1(1)\end{array}$ & 0.899 & 3 & 3 & 1 & 0.774 & 0.736 & -42.096 & -40.062 & 0.813 & 88.38 & 82.277 & 0 & 0 & 2 & 1 & 2 & 165.1 & 12 & 0.426 & 1.7 & 62.9 & 0.5 & 2 & 0 & 593.1 \\
\hline $\begin{array}{c}\text { Substrate } \\
\text { AD:1 }\end{array}$ & 0.848 & 1 & 1 & 1 & 0.733 & 0.707 & -46.327 & -44.276 & 0.76 & 92.774 & 86.621 & 0 & 0 & 12 & 1 & 10 & 245.1 & 13 & 0.245 & 1.8 & 57.5 & 3.8 & 5 & 0 & 0 \\
\hline $\begin{array}{c}\text { Substrate } \\
22: 1\end{array}$ & 0.634 & 1 & 1 & 1 & 0.762 & 0.746 & -42.76 & -40.57 & 0.777 & 86.369 & 79.799 & 0 & 0 & 2 & 2 & 2 & 174.1 & 12 & 0.231 & 2.4 & 17.1 & 0.3 & 2 & 0 & 29.4 \\
\hline $\begin{array}{c}\text { Substrate } \\
\text { AA:1 }\end{array}$ & 0.707 & 3 & 3 & 1 & 0.717 & 0.686 & -46.776 & -44.662 & 0.747 & 88.465 & 82.125 & 0 & 0 & 4 & 1 & 4 & 180.2 & 13 & 0.225 & 1.9 & 35.5 & 1.3 & 3 & 0 & 220 \\
\hline $\begin{array}{c}\text { Substrate } \\
\text { AF:1 }\end{array}$ & 0.569 & 3 & 3 & 1 & 0.708 & 0.66 & -35.541 & -33.382 & 0.756 & 74.844 & 68.366 & 0 & 0 & 2 & 1 & 10 & 112.2 & 8 & 0.051 & 1.8 & 17.1 & 1.5 & 1 & 0 & 218.3 \\
\hline $\begin{array}{c}\text { Substrate } \\
\text { D:1 }\end{array}$ & 0.687 & 1 & 1 & 1 & 0.568 & 0.476 & -34.842 & -32.781 & 0.659 & 94.686 & 88.504 & 0 & 0 & 8 & 8 & 8 & 288.3 & 20 & 0.146 & 1.7 & 88.5 & 2 & 2 & 0 & 0 \\
\hline $\begin{array}{c}\text { Substrate } \\
5: 1\end{array}$ & 0.77 & 1 & 1 & 1 & 0.755 & 0.73 & -43.61 & -41.564 & 0.78 & 82.876 & 76.738 & 0 & 0 & 3 & 1 & 3 & 154.1 & 11 & 0.278 & 2 & 37.3 & 0.8 & 2 & 0 & 0 \\
\hline $\begin{array}{c}\text { Substrate } \\
35: 1\end{array}$ & 0.657 & 2 & 2 & 1 & 0.712 & 0.631 & -34.607 & -32.56 & 0.794 & 78 & 71.861 & 0 & 0 & 2 & 2 & 2 & 121.1 & 9 & 0.293 & 1.3 & 30 & 0.3 & 1 & 0 & 60.3 \\
\hline $\begin{array}{c}\text { Substrate } \\
31: 1\end{array}$ & 0.685 & 3 & 3 & 1 & 0.801 & 0.798 & -45.027 & -42.993 & 0.804 & 80.1 & 73.998 & 0 & 0 & 2 & 2 & 2 & 120.2 & 9 & 0.391 & 1.9 & 17.1 & 0.3 & 1 & 0 & 99.1 \\
\hline $\begin{array}{c}\text { Substrate } \\
18: 1\end{array}$ & 0.756 & 2 & 2 & 1 & 0.706 & 0.623 & -29.659 & -27.629 & 0.789 & 76.64 & 70.552 & 0 & 0 & 2 & 2 & 2 & 122.1 & 9 & 0.198 & 0.7 & 42.8 & 0.3 & 1 & 0 & 50.5 \\
\hline $\begin{array}{c}\text { Substrate } \\
Y: 1\end{array}$ & 0.717 & 2 & 2 & 1 & 0.624 & 0.62 & -44.554 & -42.458 & 0.628 & 92.76 & 86.471 & 0 & 0 & 7 & 1 & 7 & 275.2 & 17 & 0.115 & 3.2 & 55.1 & 2.3 & 4 & 0 & 34.6 \\
\hline $\begin{array}{c}\text { Substrate } \\
1: 1 \\
\end{array}$ & 0.766 & 3 & 3 & 1 & 0.751 & 0.712 & -41.378 & -39.355 & 0.791 & 81.058 & 74.988 & 0 & 0 & 3 & 3 & 3 & 136.2 & 10 & 0.32 & 1.6 & 37.3 & 0.8 & 2 & 0 & 156.6 \\
\hline Substrate J:1 & 0.671 & 3 & 3 & 1 & 0.725 & 0.68 & -44.74 & -42.632 & 0.77 & 89.263 & 82.94 & 0 & 0 & 2 & 2 & 2 & 171.2 & 13 & 0.287 & 2.4 & 30 & 0.3 & 1 & 0 & 229.2 \\
\hline $\begin{array}{c}\text { Substrate } \\
14: 1\end{array}$ & 0.64 & 2 & 2 & 1 & 0.725 & 0.682 & -40.664 & -38.596 & 0.768 & 90.368 & 84.163 & 0 & 0 & 3 & 3 & 3 & 176.2 & 13 & 0.27 & 2.2 & 26.3 & 1 & 1 & 0 & 36 \\
\hline
\end{tabular}




\begin{tabular}{|c|c|c|c|c|c|c|c|c|c|c|c|c|c|c|c|c|c|c|c|c|c|c|c|c|c|}
\hline Title & $\begin{array}{l}\text { Radial } \\
\text { Plot }\end{array}$ & $\begin{array}{l}\text { Activity } \\
\text { (Specific } \\
\text { Enzyme } \\
\text { Activity) }\end{array}$ & $\begin{array}{l}\text { Support Vector Machine } \\
\text { Classification (Specific } \\
\text { Enzyme Activity) }\end{array}$ & $\begin{array}{c}\text { Alignment } \\
\text { Chosen }\end{array}$ & Sim & FSim & FScore & FScore+P & SSim & SScore & SScore+P & $\begin{array}{l}\text { Excl } \\
\text { Vol } \\
\text { Pen }\end{array}$ & $\begin{array}{c}\text { Field } \\
\text { Pen }\end{array}$ & Confs & Conf\# & Alns & $\mathrm{MW}$ & $\begin{array}{c}\text { \#Ato } \\
\text { ms }\end{array}$ & 2D Sim & SlogP & TPSA & $\begin{array}{c}\text { Flexibi } \\
\text { lity }\end{array}$ & \#RB & Rof5 & $\begin{array}{c}\text { Exp. } \\
\text { Specific } \\
\text { Enzyme } \\
\text { Activity }\end{array}$ \\
\hline $\begin{array}{c}\text { Substrate } \\
0: 1\end{array}$ & 0.659 & 3 & 3 & 1 & 0.739 & 0.73 & -42.281 & -40.245 & 0.748 & 81.608 & 75.499 & 0 & 0 & 3 & 3 & 3 & 150.2 & 11 & 0.301 & 1.9 & 26.3 & 0.8 & 2 & 0 & 396.7 \\
\hline $\begin{array}{c}\text { Substrate } \\
26: 1\end{array}$ & 0.495 & 3 & 3 & 1 & 0.648 & 0.618 & -37.595 & -35.356 & 0.678 & 72.661 & 65.943 & 0 & 0 & 4 & 1 & 4 & 134.2 & 10 & 0.362 & 1.8 & 17.1 & 2 & 2 & 0 & 239.4 \\
\hline
\end{tabular}


Activity Miner compound pairings

Substrate pairs showing greatest disparity between field similarity and specific enzyme activity with (S)-ADH

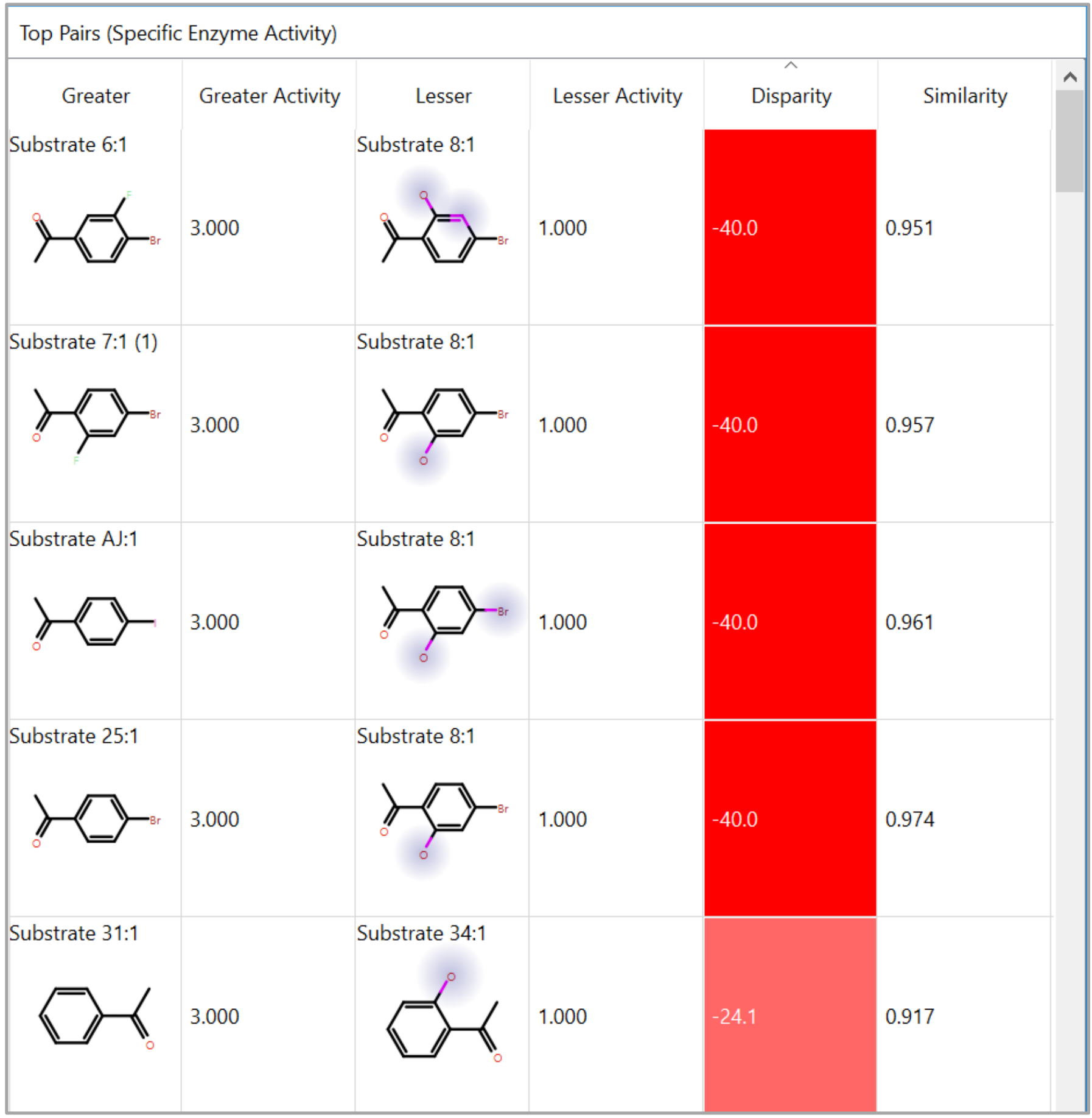




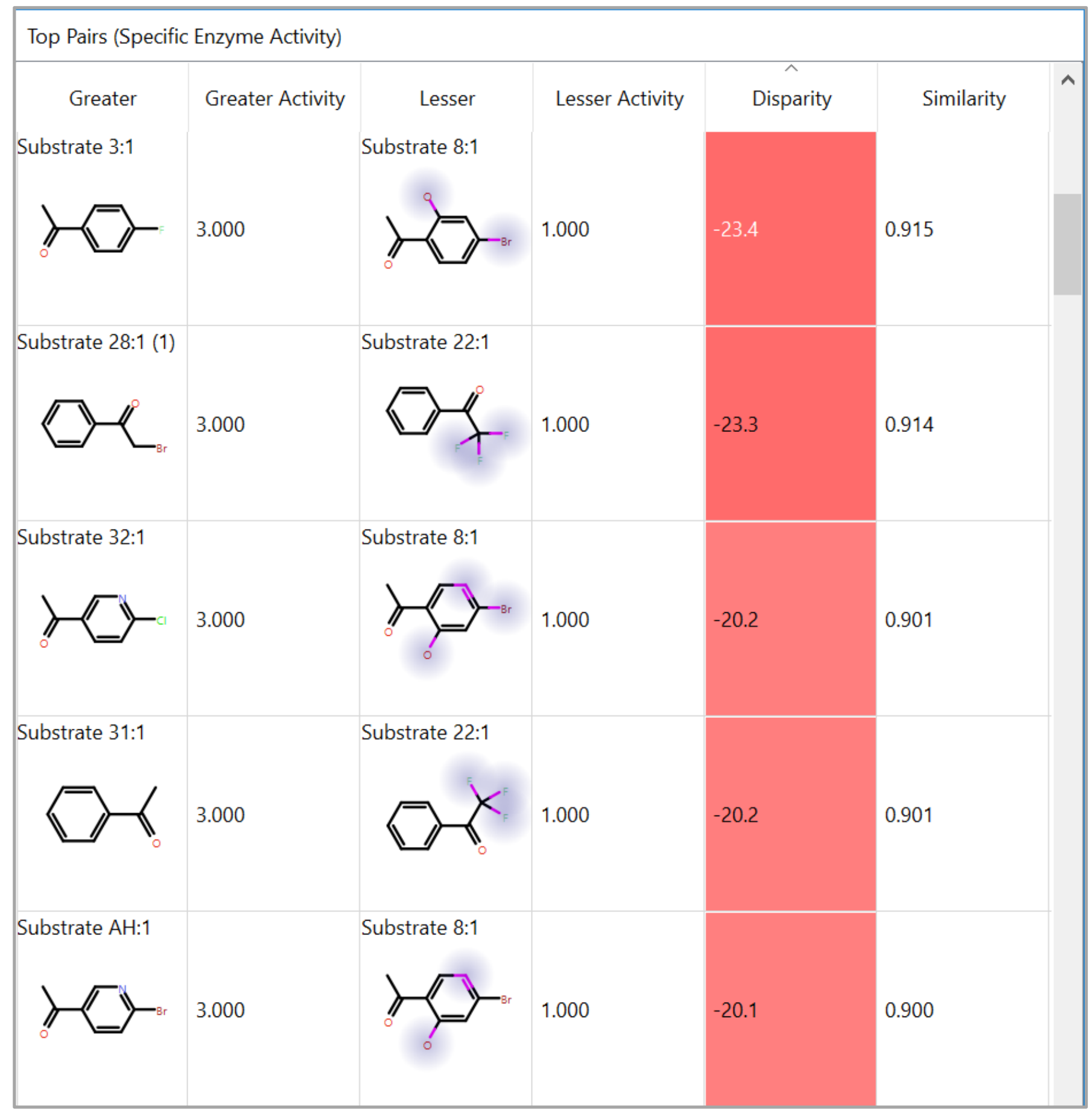




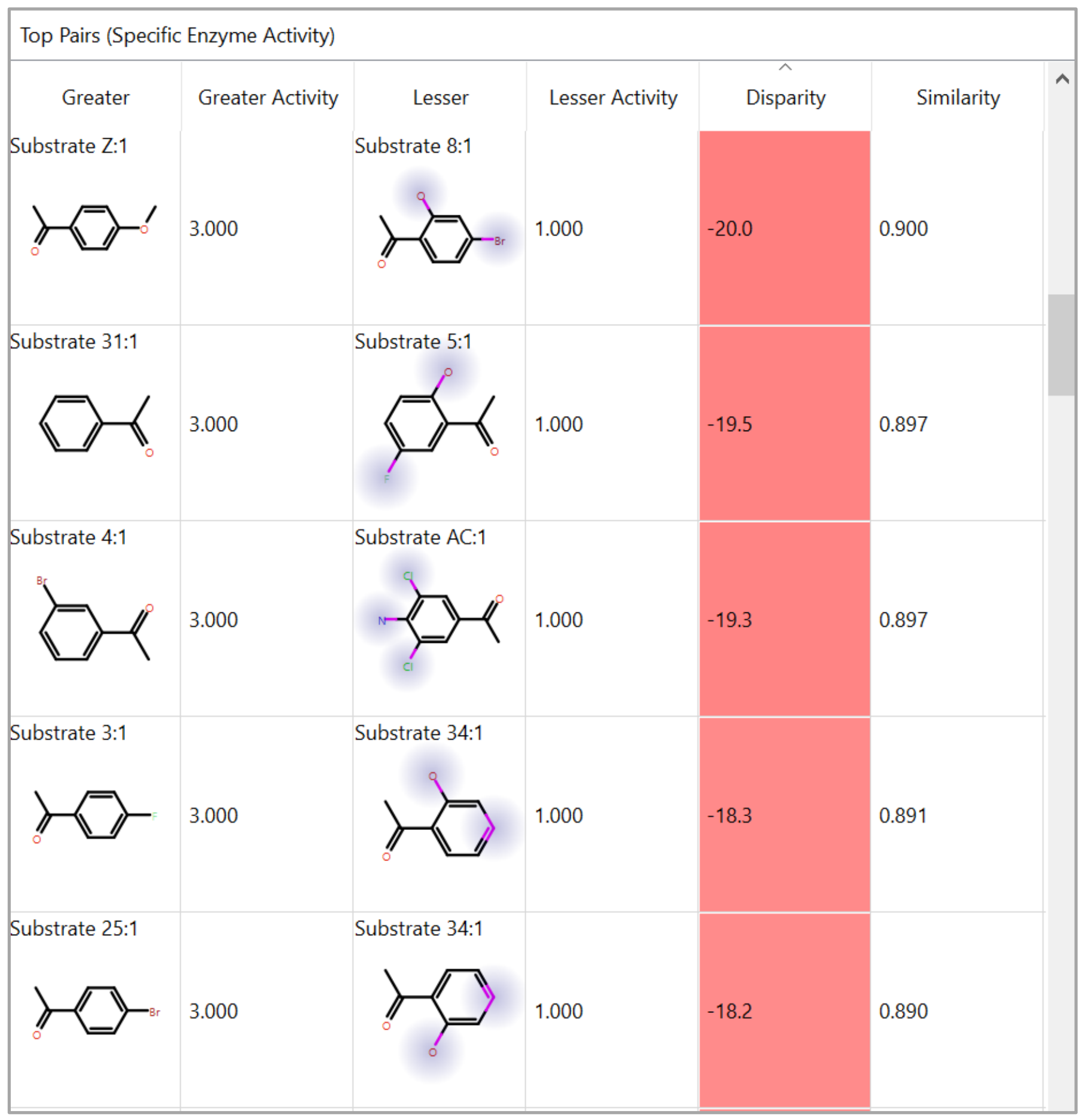




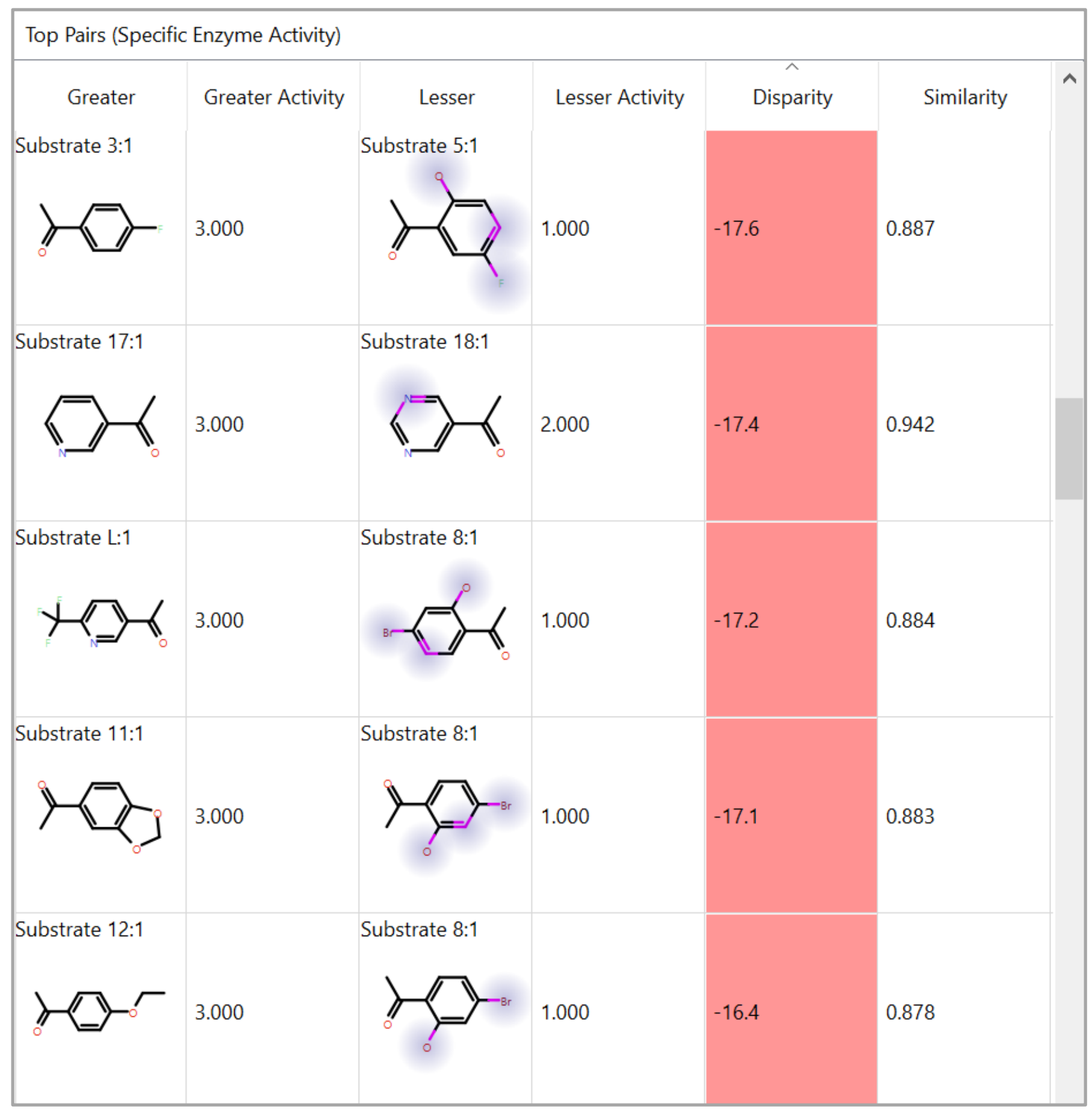




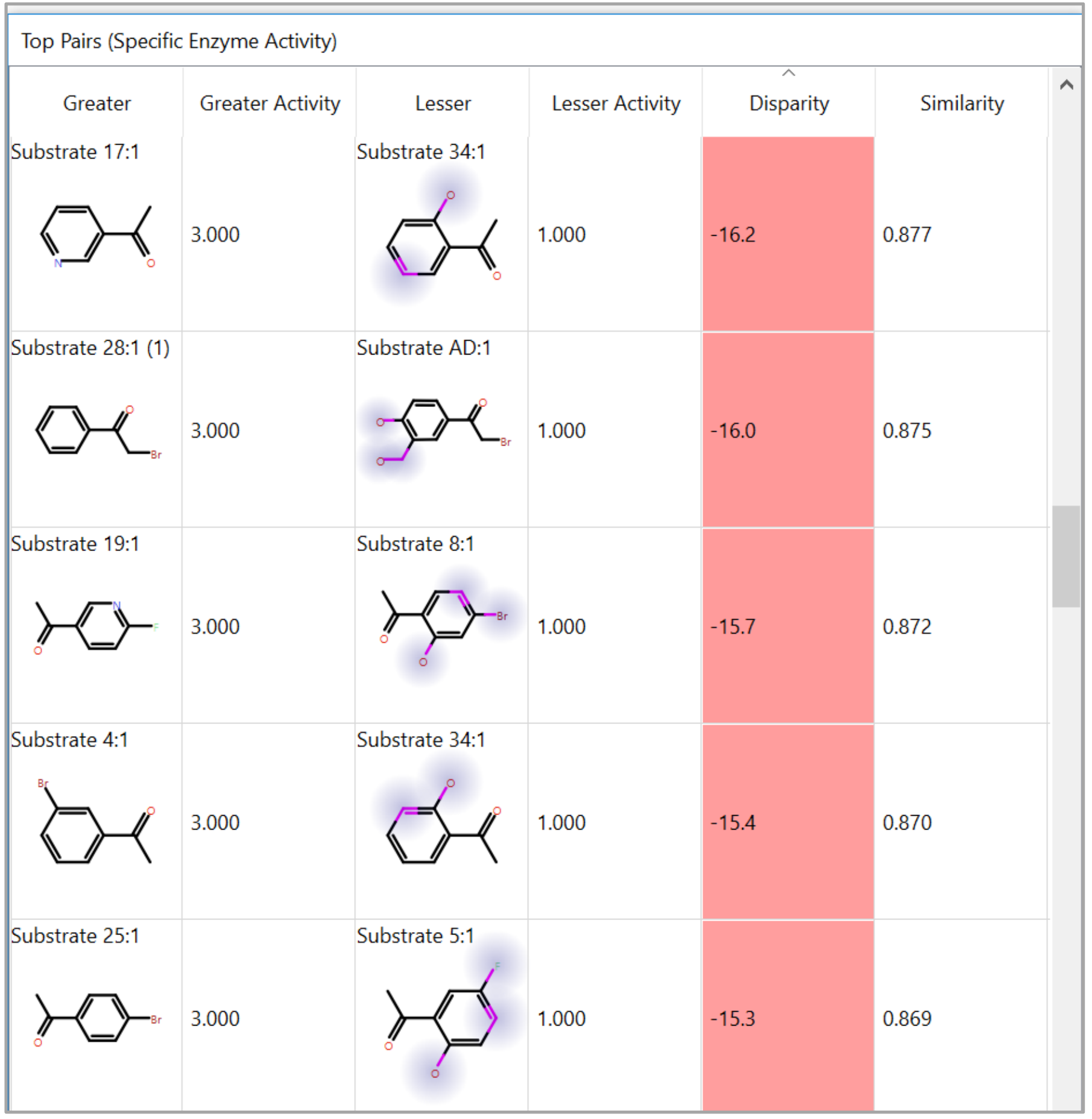




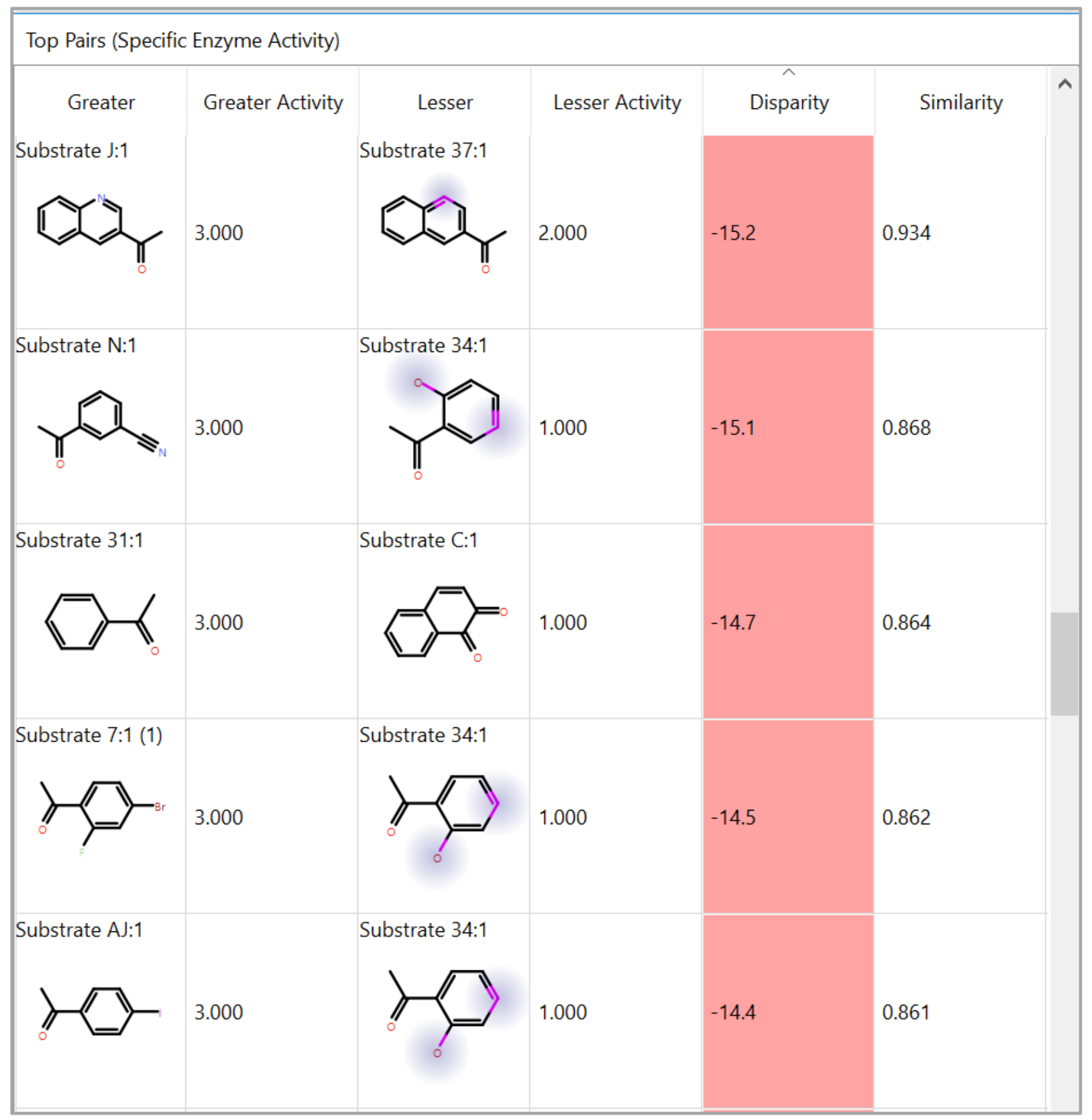




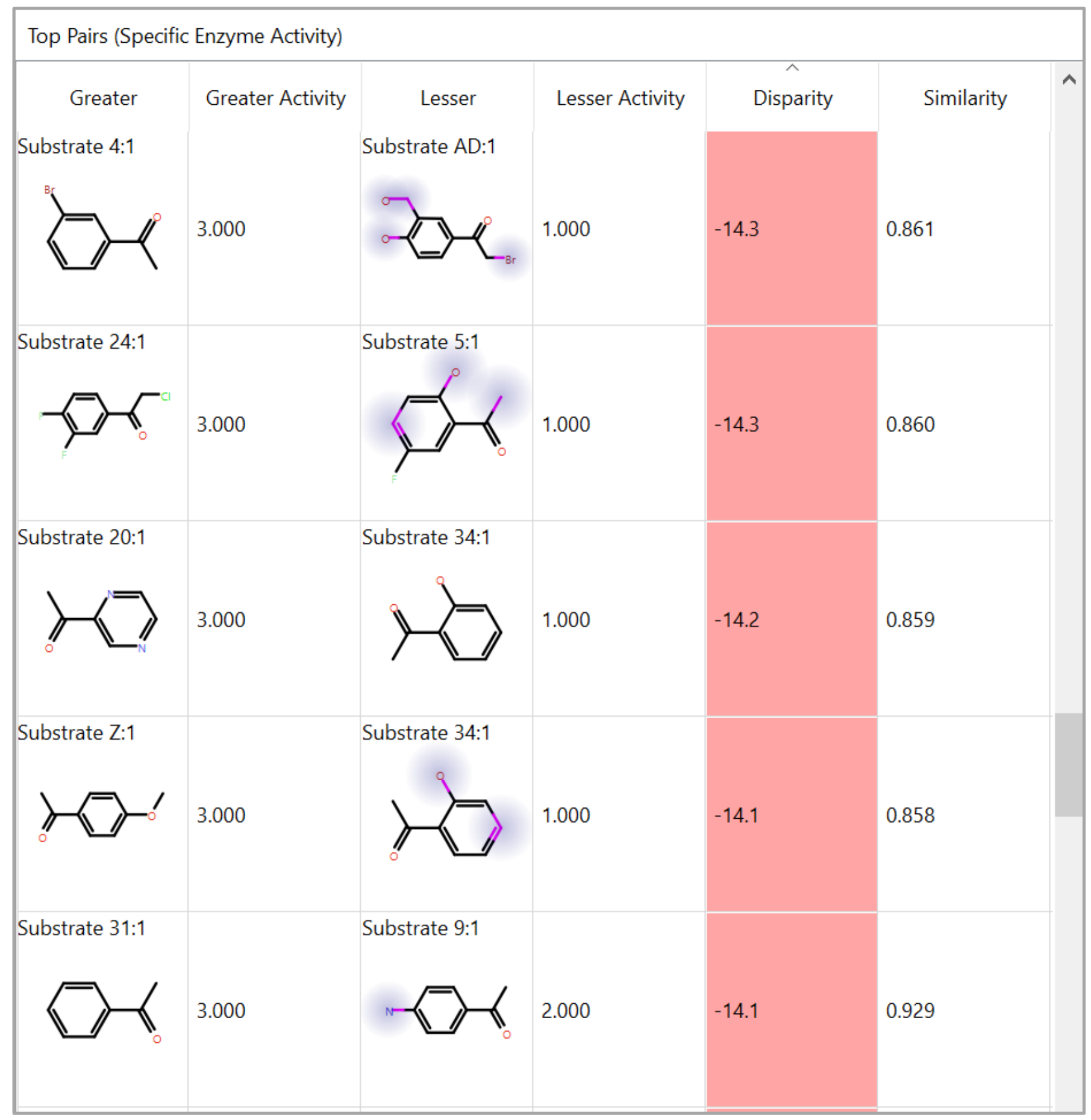




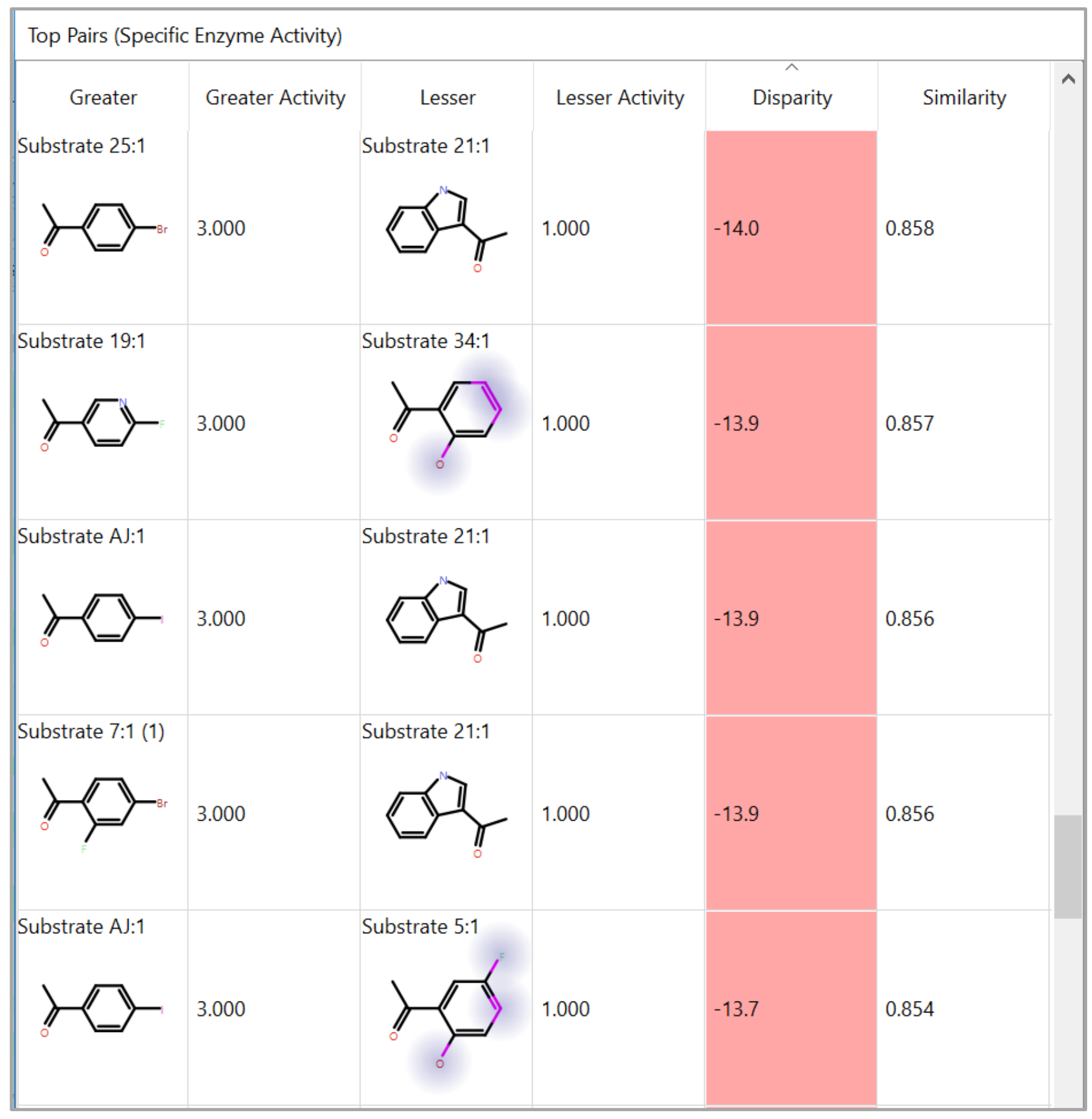




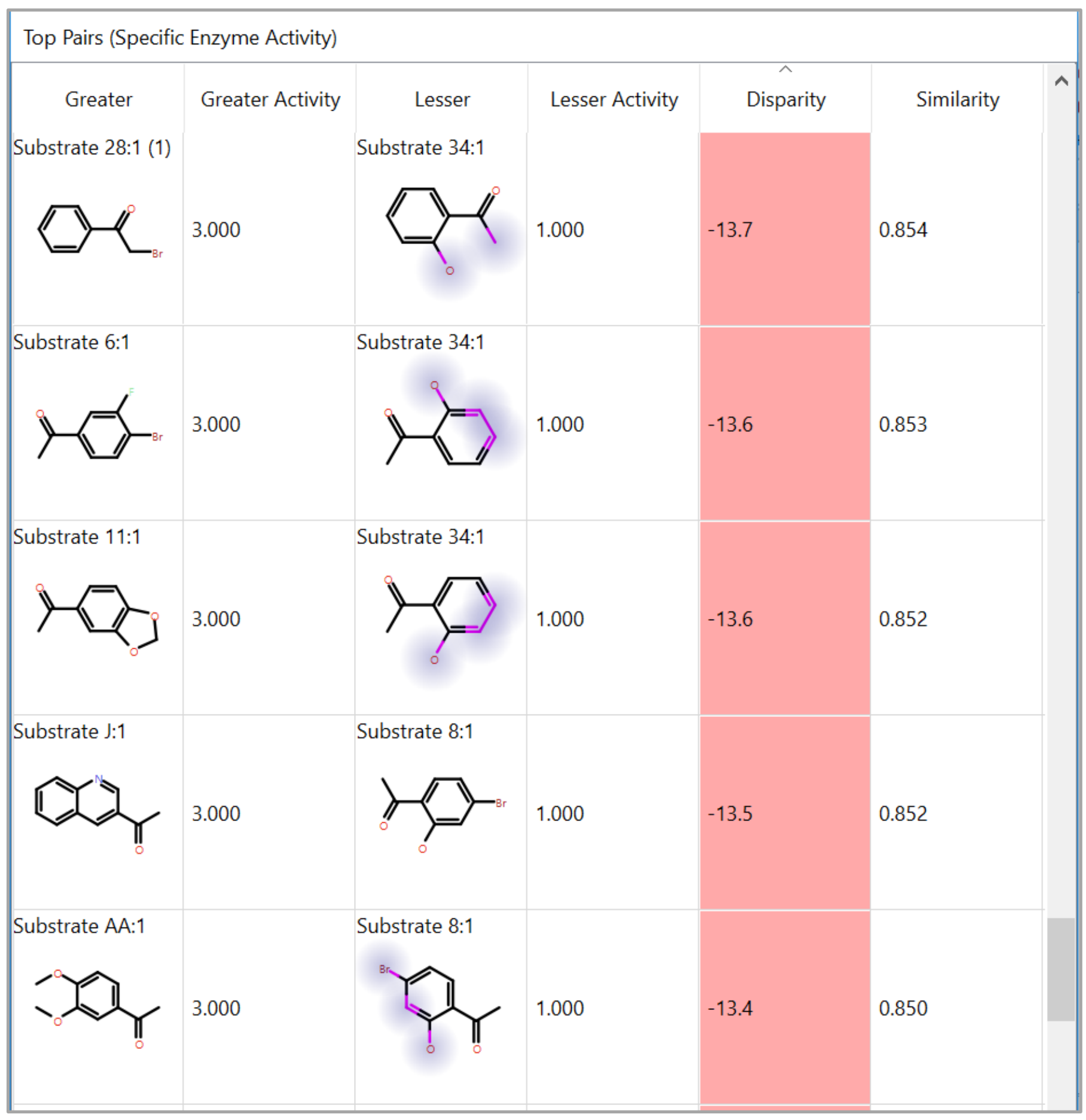




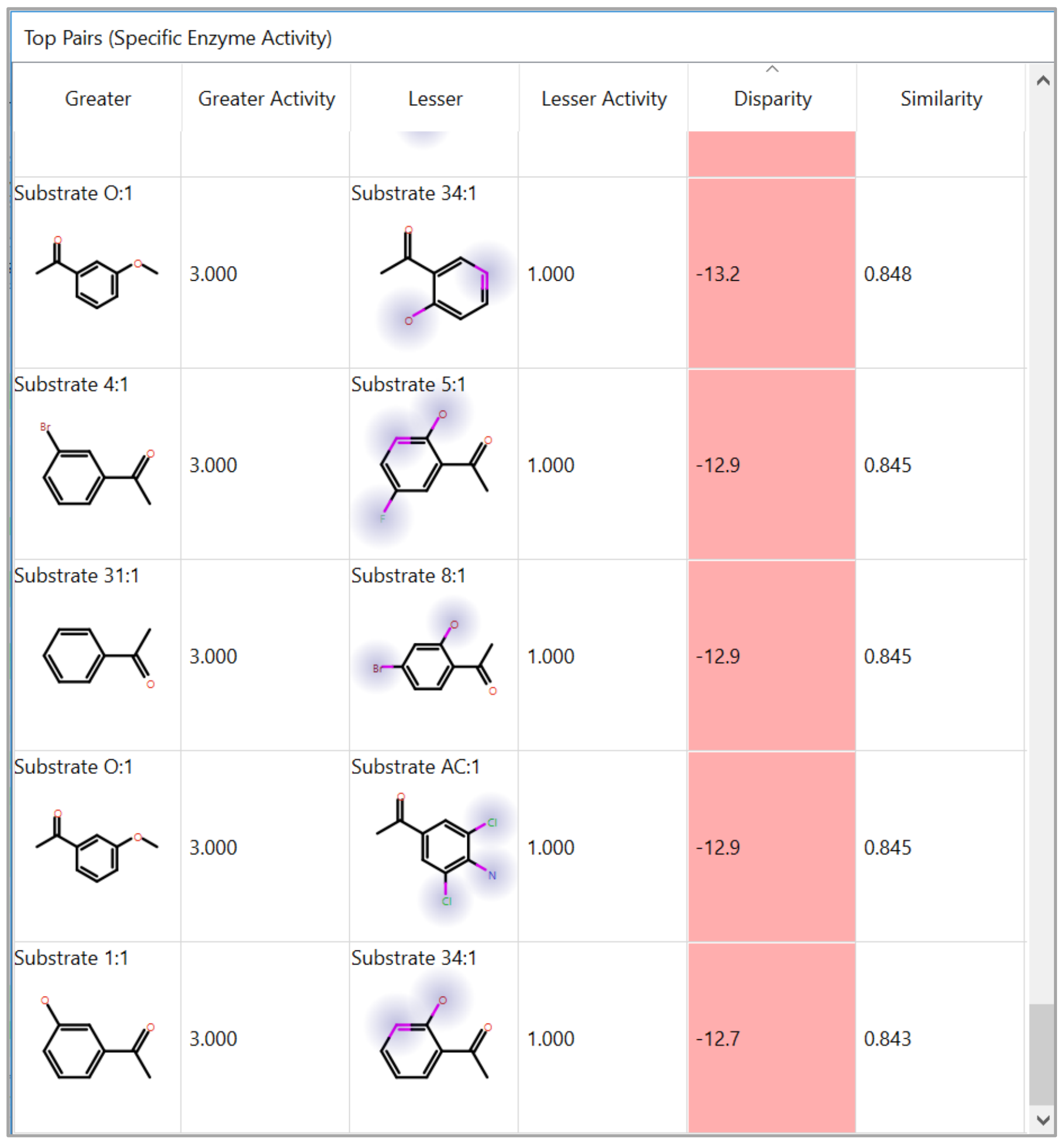

References

1 J. S. Rowbotham, M. A. Ramirez, O. Lenz, H. A. Reeve and K. A. Vincent, Nat. Commun., 2020, 11, 1-7. 